\title{
FRIGOCONSERVAÇÃO E VERNALIZAÇÃO DE MUDAS DE MORANGUEIRO (FRAGARIA X ANANASSA DUCH.) PRODUZIDAS EM SISTEMA DE VASOS SUSPENSOS
}

\author{
MARCELO FONTANETTI VERDIAL
}

\author{
Tese apresentada à Escola Superior de Agricultura "Luiz \\ de Queiroz", Universidade de São Paulo, para obtenção \\ do título de Doutor em Agronomia, Área de \\ Concentração: Fitotecnia.
}

P I R A C I C A B A

Estado de São Paulo - Brasil

Março - 2004 


\section{FRIGOCONSERVAÇÃO E VERNALIZAÇÃO DE MUDAS DE MORANGUEIRO (FRAGARIA X ANANASSA DUCH.) PRODUZIDAS EM SISTEMA DE VASOS SUSPENSOS}

\section{MARCELO FONTANETTI VERDIAL}

Engenheiro Agrônomo

Orientador: Prof. Dr. KEIGO MINAMI

Tese apresentada à Escola Superior de Agricultura "Luiz de Queiroz", Universidade de São Paulo, para obtenção do título de Doutor em Agronomia, Área de Concentração: Fitotecnia.

P I R A C I C A B A

Estado de São Paulo - Brasil

Março - 2004 


\section{Dados Internacionais de Catalogação na Publicação (CIP) DIVSÃO DE BIBLIOTECA E DOCUMENTAÇ̃̃O - ESALQ/USP}

Verdial, Marcelo Fontanetti

Frigoconservação e vernalização de mudas de morangueiro (Fragaria x Ananassa Duch.) produzidas em sistemas de vasos suspensos / Marcelo Fontanetti Verdial. - - Piracicaba, 2004

71 p. : il.

Tese (doutorado) - Escola Superior de Agricultura Luiz de Queiroz, 2004. Bibliografia.

1. Carboidratos (Teor) 2. Cultivo protegido 3. Morango 4. Mudas (Produção) 5. Sistema de produção 6. Variedades vegetais 7. Vernalização I. Título

CDD 634.75

\section{"Permitida a cópia total ou parcial deste documento, desde que citada a fonte - $\mathrm{O}$ autor"}


Ao amigo João, Dedico 


\section{AGRADECIMENTOS}

À Deus.

À Universidade de São Paulo - Escola Superior de Agricultura "Luiz de Queiro”, através do Departamento de Produção Vegetal, pelas condições dadas para o desenvolvimento dessa pesquisa.

Ao Professor e amigo Dr. João Tessarioli Neto, pela orientação, amizade e confiança em mim depositada.

Aos Professores Keigo, João Aleixo, Pedro e Ricardo Kluge pelo apoio prestado.

Aos funcionários do Departamento de Produção Vegetal, e em especial ao Cido, Galdencio, Bete, Célia e Helena pela colaboração e amizade.

Ao pesquisador Jaime Duarte (EPAMIG) pela ajuda na condução da parte experimental de Caldas,MG.

Ao Dr. Francisco Passos pela colaboração na correção e finalização do trabalho.

Aos funcionários da Biblioteca central, em especial a Silvia pelas correções.

À FAPESP, pelo apoio financeiro.

À todos que de uma forma ou de outra contribuíram para que este trabalho pudesse ser realizado e concluído. 


\section{SUMÁRIO}

Página

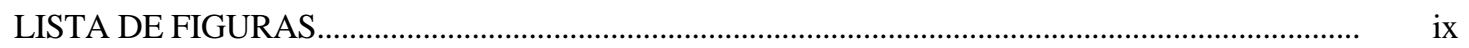

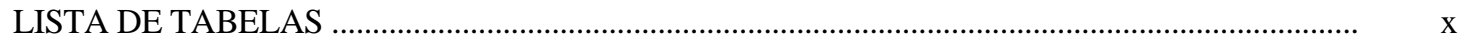

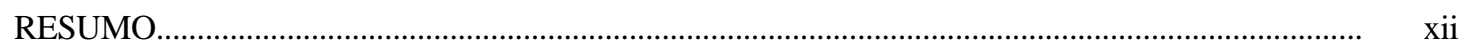

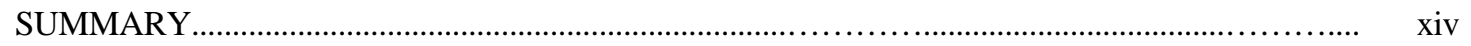

1 INTRODUÇÃ

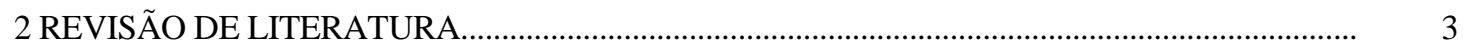

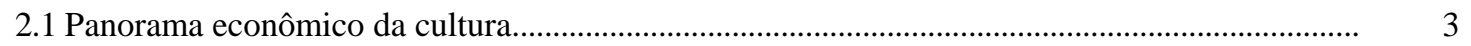

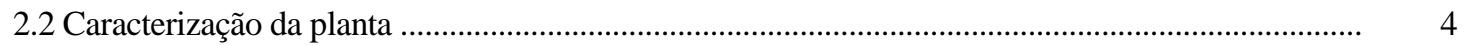

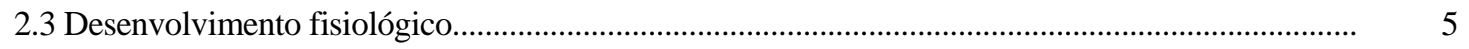

2.3.1 Influência do ambiente no desenvolvimento do morangueiro.......................................................

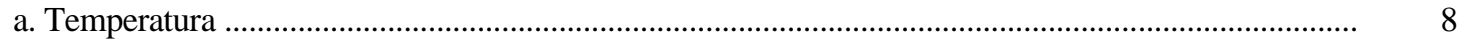

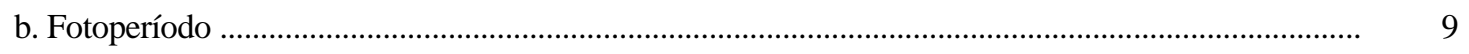

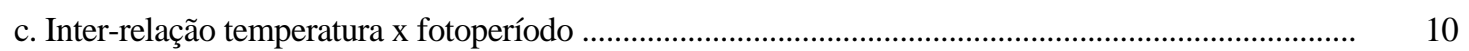

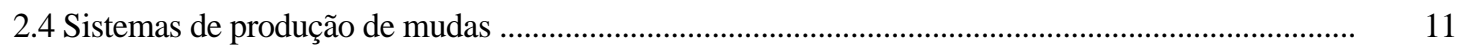

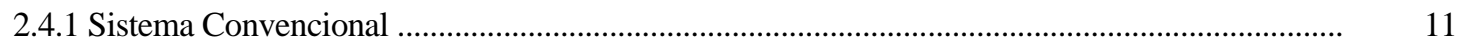

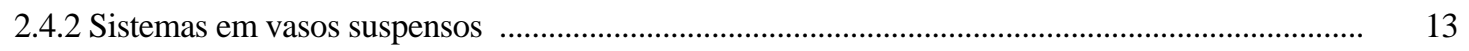

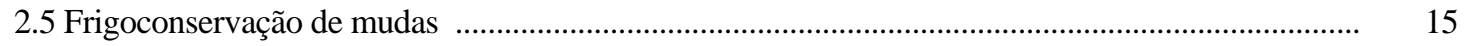

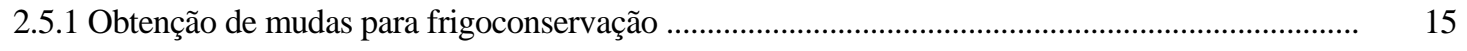

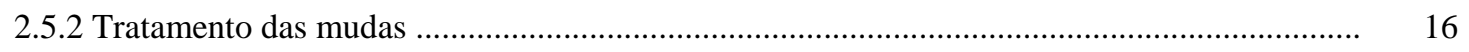

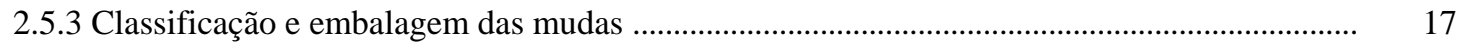

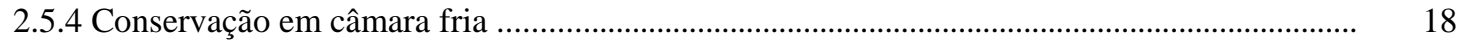




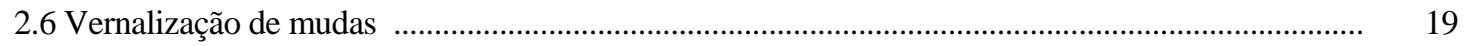

2.7 plantas de morangueiro com coroas múltiplas ……………………………………........................... 20

3 TEORES DE CARBOIDRATOS TOTAIS E SOBREVIVENCIA DE MUDAS DE MORANGUEIRO PRODUZIDAS EM SISTEMA CONVENCIONAL E EM VASOS

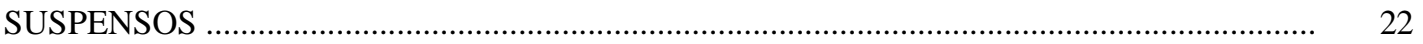

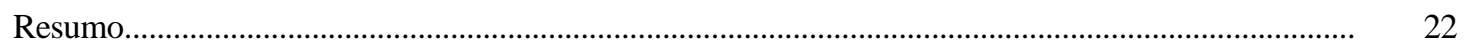

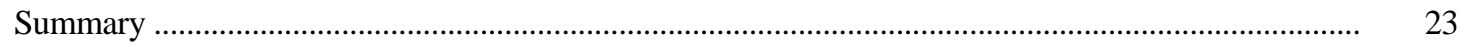

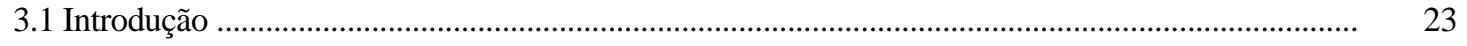

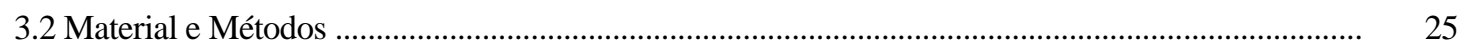

3.2.1 Cultivares e tratamentos ...................................................................................................... 25

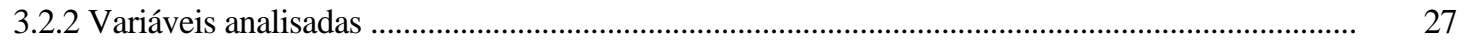

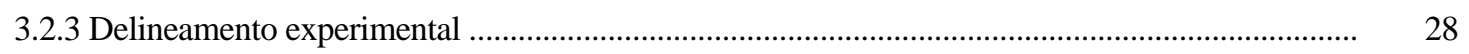

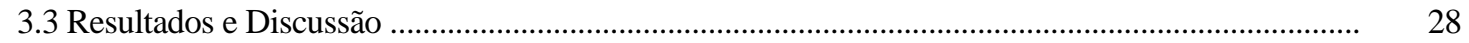

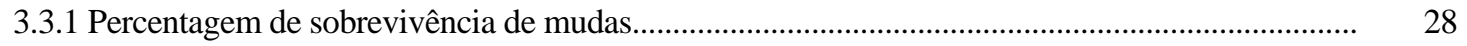

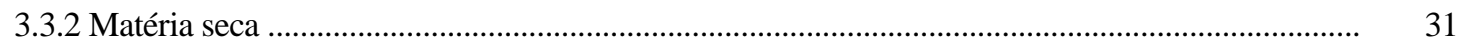

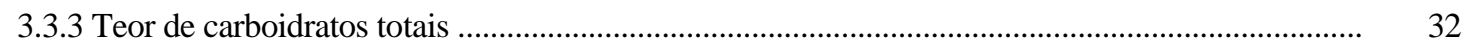

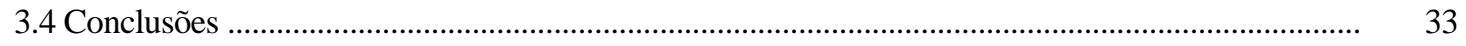

4 FRIGOCONSERVAÇÃO DE MUDAS DE MORANGUEIRO PRODUZIDAS EM SISTEMA

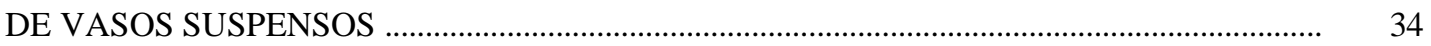

Resumo

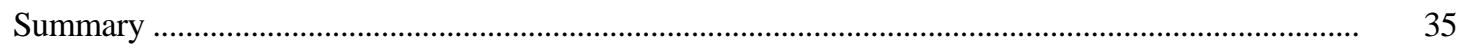

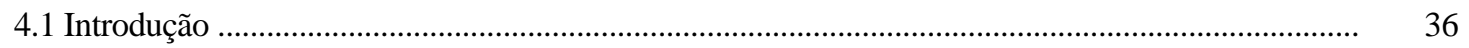

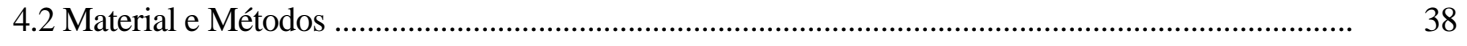

4.2.1 Experimento 2000-2001 ………………………...................................................................

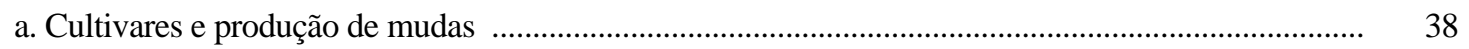

b. Coleta e classificação das mudas ......................................................................................................

c. Tratamento das mudas ............................................................................................................... 


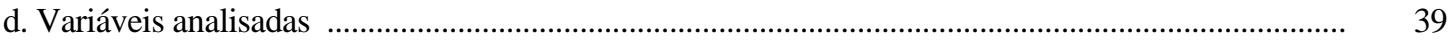

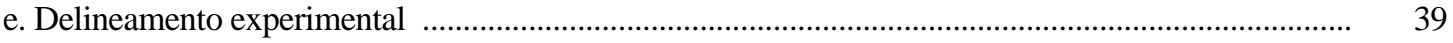

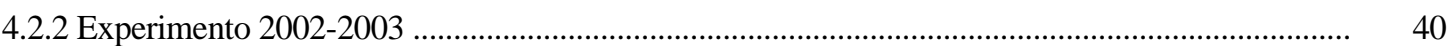

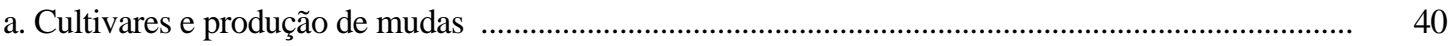

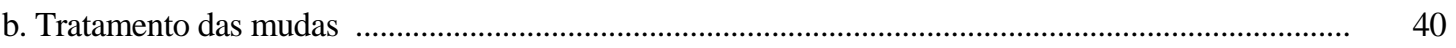

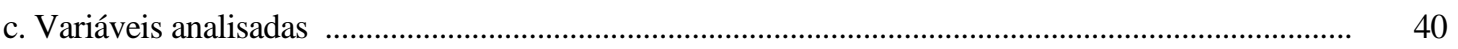

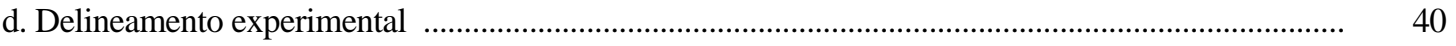

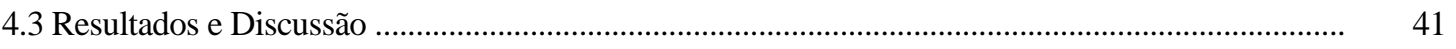

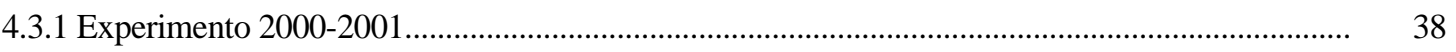

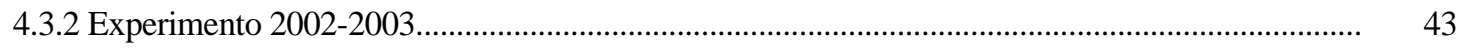

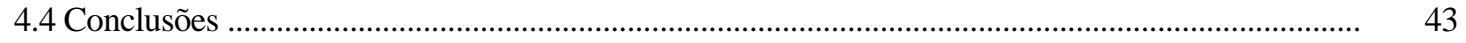

5 EFEITO DA VERNALIZAÇÃO EM MUDAS CONICIONADAS DE MORANGUEIRO

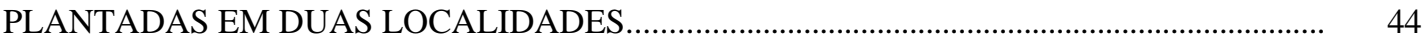

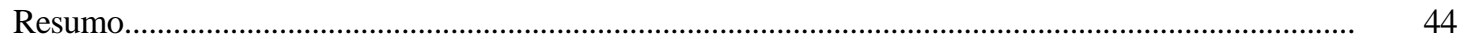

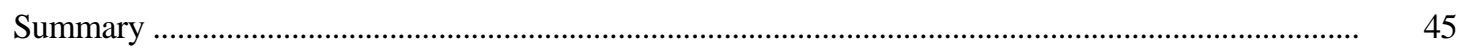

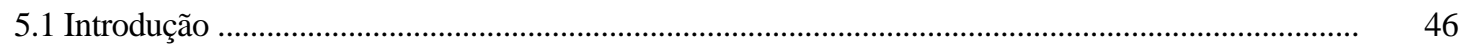

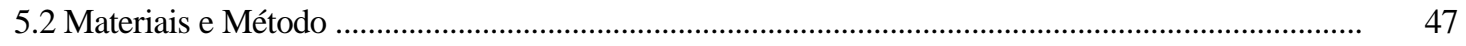

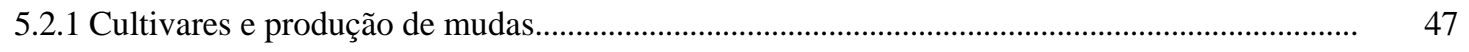

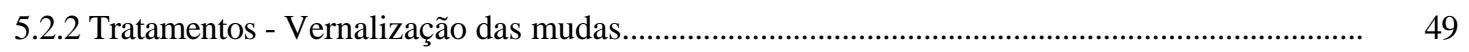

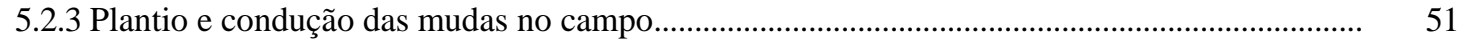

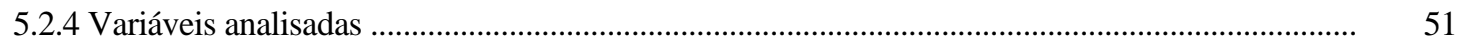

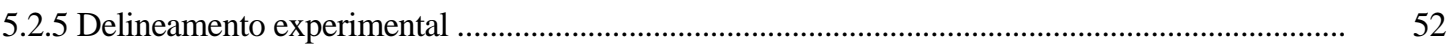

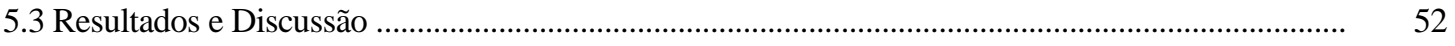

5.3.1 Percentagem de sobrevivência de mudas................................................................................

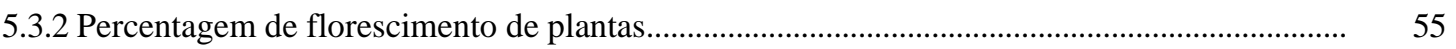

5.3.3 Percentagem de frutificação de plantas.................................................................................... 58

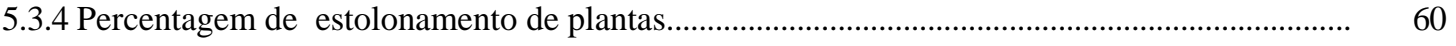


5.3.5 Peso e número de frutos produzidos...

5.4 Conclusões

64

6 CONCLUSÕES GERAIS..

65

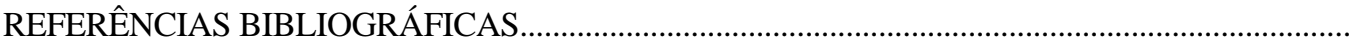

66 


\section{LISTA DE FIGURAS}

Página

1 Canteiro de produção de mudas de morangueiro em sistema convencional. Jarinú/SP, 2004..

2 Coleta de mudas de morangueiro em sistema convencional. Detalhe das raízes nuas. Jarinú/SP, 2004.

3 Produção de mudas de morangueiro em vasos suspensos baseado no sistema desenvolvido por Tessarioli Neto (2001). Jarinú/SP, 2004

4 Matrizes de morangueiro durante a produção de mudas em sistema de vasos suspensos sob cultivo protegido. Piracicaba, 2001..

5 Matrizes de morangueiro durante a produção de mudas em sistema convencional sob cultivo protegido. Piracicaba, 2001

6 Sistema de produção de mudas de morangueiro em vasos supensos. Piracicaba/SP, 2002..............

7 Mudas de morangueiro em vasos durante o período de “espera”. Piracicaba/SP, 2002............

8 Sistema de vernalização de mudas de morangueiro em câmara fria. Piracicaba/SP, 2003........

9 Canteriros de finais de experimentação.Caldas/MG, 2002.

10 Morte de mudas de morangueiro devido à ação do fungo Colletotrichum fragariae. Caldas/MG, 2003

11 Comparativo entre as temperaturas médias diárias observadas nas localidades de Caldas/MG e Piracicaba/SP, do período de 01/12/2002 a 28/02/2003 ......

12 Frutos de tamanho reduzido e apresentando defeitos devido às altas temperaturas. Piracicaba/SP, 2003. 


\section{LISTA DE TABELAS}

1 Produção de Morango no Estado de São Paulo, Instituto de Economia Agrícola e Coordenadoria de Assistência Técnica Integral 1997-2001

2 Parâmetros e categorias adotadas para avaliação das mudas coletadas por Ortigoza, Piracicaba, 1999

3 Percentagem de sobrevivência de mudas aos 15 e 30 dias após o plantio, para as cultivares de morangueiro IAC-Campinas, IAC-Guarani e Pelican produzidas nos sistemas de vasos suspensos e convencional. Piracicaba, 2002.

4 Matéria seca (g/kg) para as cultivares de morangueiro IAC-Campinas, IAC-Guarani e Pelican produzidas nos sistemas de vasos suspensos e convencional. Piracicaba, 2002

5 Teor de carboidratos totais (mg/100ml de extrato) para as cultivares de morangueiro IACCampinas, IAC-Guarani e Pelican produzidas nos sistemas de vasos suspensos e convencional. Piracicaba, 2002.

6 Percentagem de sobrevivência de mudas de morangueiro frigoconservadas após 21 dias de plantio (\%PT 21) e após 30 dias do transplante para os vasos (\%30d/I), Piracicaba, 2001.

7 Percentagem de sobrevivência de mudas de morangueiro frigoconservadas após 21 dias de plantio (\%PT 21) e após 30 dias do transplante para os vasos (\%30d/I), em função da aplicação ou não de IBA, Piracicaba, 2003.

8 Percentagem de sobrevivência de mudas aos 15, 30, 45 e 60 dias após o transplante em função da cultivar e da vernalização (Vern) ou não (Test) das mudas para as localidades de Piracicaba/SP e Caldas/MG, 2003......

9 Percentagem de florescimento de plantas aos 15 e 30 dias após o transplante em função da cultivar e da vernalização (Vern) ou não (Test) das mudas para as localidades de Piracicaba/SP e Caldas/MG, 2003.

10 Percentagem de frutificação de plantas aos 45 e 60 dias após o transplante em função da cultivar e da vernalização (Vern) ou não (Test) das mudas para as localidades de Piracicaba/SP e Caldas/MG, 2003.

11 Percentagem de estolonamento de plantas aos 15, 30, 45 e 60 dias após o transplante em função da cultivar e da vernalização (Vern) ou não (Test) das mudas para as localidades de Piracicaba/SP e Caldas/MG, 2003...... 
12 Peso e número de frutos em função da cultivar e da vernalização (Vern) ou não (Test) das mudas para as localidades de Piracicaba/SP e Caldas/MG, 2003.............................................. 


\title{
FRIGOCONSERVAÇÃO E VERNALIZAÇÃO DE MUDAS DE MORANGUEIRO (FRAGARIA X ANANASSA DUCH.) PRODUZIDAS EM SISTEMA DE VASOS SUSPENSOS
}

\author{
Autor: MARCELO FONTANETTI VERDIAL \\ Orientador: Prof. Dr. KEIGO MINAMI
}

\section{RESUMO}

Com o objetivo de estudar o sistema de produção de mudas de morangueiro em vasos suspensos e a aplicação das técnicas de frigoconservação e vernalização nas mudas produzidas nesse sistema, foram realizados quatro experimentos no Departamento de Produção Vegetal, ESALQ/USP, Piracicaba/SP, no período compreendido entre janeiro de 2000 e junho de 2003. No primeiro experimento comparou-se o sistema de produção de mudas em vasos suspensos com o sistema convencional. Foram avaliados: matéria seca, teor de carboidratos totais e percentagem de sobrevivência de mudas. Foram utilizadas as cultivares IAC-Campinas, Pelican e IAC-Guarani. Foi utilizado o delineamento experimental em esquema fatorial 3x2 (três cultivares e dois sistemas de produção de mudas), com três repetições. As mudas produzidas em vasos suspensos apresentaram maior percentagem de sobrevivência e maiores teores de carboidratos totais. O segundo e terceiro experimentos tiveram como objetivo avaliar o uso da técnica de frigoconservação em mudas produzidas no sistema de vasos suspensos. As mudas foram acondicionadas em sacos de polietileno e frigoconservadas durante 120 dias em uma B.O.D. a $-1 \pm 1^{\circ}$ C. Foram então retiradas da 
câmara fria e plantadas em bandejas de poliestireno expandido de 128 células preenchidas com vermiculita. As bandejas foram colocadas em uma câmara nebulizadora, onde permaneceram por 21 dias para enraizamento. Em seguida foram transplantadas para vasos de $250 \mathrm{ml}$ e levadas para casa de vegetação. Foi avaliada a percentagem de sobrevivência das mudas. No segundo experimento utilizou-se o delineamento experimental inteiramente ao acaso com cinco cultivares (IAC-Campinas, Dover, Pelican, Sequoia e Sweet Charlie) e nove repetições. No terceiro experimento foi utilizado o esquema fatorial 5x2 (cinco cultivares: IAC-Campinas, Oso Grande, Camarosa, Dover e Sweet Charlie; e dois tratamentos de enraizamento: com e sem ácido indol butírico) com quatro repetições. O sistema de frigoconservação adotado apresenou desempenho insatisfatório devido à baixa percentagem de sobrevivência das mudas. $\mathrm{O}$ quarto experimento estudou o efeito da vernalização em mudas de cinco cultivares de morangueiro produzidas no sistema de vasos suspensos. As mudas foram plantadas em vasos de $250 \mathrm{ml}$, preenchidos com substrato formulado com areia e vermiculita (4:1) e mantidas em casa de vegetação durante seis meses. O delineamento experimental utilizado foi o fatorial 5x2, com cinco cultivares (IAC-Campinas, Dover, Sweet Charlie, Cartuno e Oso Grande) com e sem vernalização das mudas, com quatro repetições. Para vernalização, as mudas foram levadas para câmara fria, à temperatura de $10 \pm 2{ }^{\circ} \mathrm{C}$, e fotoperíodo de 10 h de luz/dia, durante 28 dias. Em seguida, foram transplantadas para dois locais de cultivo com características climáticas distintas, Piracicaba,SP e Caldas,MG. Foram avaliadas as percentagens de sobrevivência, florescimento, frutificação e emissão de estolhos e o peso da matéria fresca e número de frutos produzidos por planta. A sobrevivência de mudas não foi afetada pela vernalização em nenhuma das localidades. Houve efeito significativo no florescimento e na frutificação das plantas vernalizadas apenas em Piracicaba. O estolonamento de plantas foi mais precoce em Piracicaba. Para todas as cultivares a produção de frutos foi e insignificante e comercialmente inviável em ambas as localidades.

PALAVRAS CHAVE: produção de mudas, cultivo protegido, teor de carboidratos totais, condicionamento de mudas, sistemas de produção de mudas. 


\title{
STORAGE COLD AND VERNALIZATION OF STRAWBERRIES RUNNER (FRAGARIA X ANANASSA DUCH.) PRODUCED IN SUSPEND POTS SYSTEM
}

\author{
Author: MARCELO FONTANETTI VERDIAL \\ Adviser: Prof. Dr. KEIGO MINAMI
}

\section{SUMMARY}

With the objective of studying the runners production system in suspended pots under protected cultivation and the application of techniques of stored cold and vernalization of runners produced by this system, four experiments were conducted in the Department of Crop Production, ESALQ, Piracicaba, SP-Brazil. In the first experiment it was compared the conventional strawberry runners production system with the runner production system in suspended pots. For that, it was measured the dry matter and carbohydrates contents in runners and the survival percentage when the runner were transplanted to field production areas. The cultivars IAC-Campinas, Pelican and IACGuarani were used, in an experimental design of factorial arrangement 3x2 (three cultivars and two runners production systems), three replications. The runners produced by the system of suspended pots accumulated higher amount of total carbohydrates and the plant survival rate. The second and third experiments had the objective of evaluating the use of a technique of storage cold in runners produced in the system of suspended pots. After the selection, the runners were conditioned in polyethylene bags and storage cold conditions for 120 days in a B.O.D. at $-1 \pm 1^{\circ} \mathrm{C}$. After that they were removed of the 
cold camera and planted in trays of expanded polystyrene of 128 cells with vermiculite. The trays were put in a spray chamber 21 days for rooting. After that hey were transplanted to pots of $250 \mathrm{~mL}$ and then placed in the greenhouse. It was evaluated the percentage of runners survival. In the second experiment it was used the experimental entirely random design, five strawberry cultivars (IAC-Campinas, Dover, Pelican, Sequoia and Sweet Charlie), and nine repetitions. In the threat experiment the factorial outline used was $5 \times 2$ (five cultivars: IAC-Campinas, Big Oso, Camarosa, Dover and Sweet Charlie; and two treatments: with and without indol butyric acid) with four repetitions. The storage cold of strawberry runners produced in system of suspended pots lower percentage of survival of seedlings in the two experiments. Therefore, the system of storage cold was not compatible with the type of storage runners. The fourth experiment had the objective of studying the effect of the runner vernalization of five strawberry cultivars produced in suspended pot system. In order to have availability of strawberry runners during the off season, they were planted in pots of $250 \mathrm{~mL}$, filled out with substrate formulated with sand and vermiculite (4:1) and kept in the greenhouse for six months. Completely randomized blocks with the factorial design $5 x 2$, with five strawberry cultivars (IAC-Campinas, Dover, Sweet Charlie, Cartuno and Big Oso) and two treatments (with and without strawberry runners vernalization). For vernalization, the strawberry runners were taken from cold camera to the temperature of $10+2^{\circ} \mathrm{C}$, and fotoperiod of $10 \mathrm{~h}$ of light/day for 28 days. After that, they were transplanted for two cultivation places with different climatic conditions, Piracicaba/SP and Caldas/MG. They were analyzed the survival percentages, flower blooming, fructification and emission of stolons and the weight and number of fruits produced by plant. The strawberry runners survival was not affected by the vernalization in none of the places. There were only significant effect on flower appearance and fructification of the vernalized plants, only in Piracicaba. The runner emitions were earlier in Piracicaba. For all strawberry cultivars the production of fruits was very low and the produced fruits were unsuitable for commercialization in both places.

KEYWORDS: runners production, protected cultivation, carbohydrate content, conditioning of runners, runners production system. 


\section{INTRODUÇÃO}

O morango apresenta-se como uma opção de atividade econômica viável em vários estados brasileiros, adequando-se à produção familiar. Apesar da produção brasileira não configurar junto aos grandes produtores mundiais, existe viabilidade de aumentar a produção através de diversas técnicas e desenvolvimento de novos cultivares. Devido à alta perecibilidade, a comercialização na forma de polpas processadas e congeladas apresenta-se como opção interessante para exportação, viabilizando o consumo na forma de sucos, geléias e ingredientes para sobremesas. O morango é uma fruta cujo apelo de marketing é muito forte, o que permite a organização de festivais no período de pico da safra associados ao turismo regional e a festivais de doces e tortas, em forma de sobremesas em redes de fast food, gerando empregos e renda no setor de serviços (Sato \& Assumpção, 2002).

De acordo com os mesmos autores, dados da EMBRAPA demonstram que o principal aspecto que tem despertado o interesse pela exploração desta atividade é a alta rentabilidade que proporciona, quando comparada a outras culturas como milho (72\% superior) e soja (224\% superior). Seja para o consumo in natura ou para o processamento, o morango tem alcançado cotações relativamente elevadas, pelo fato de não encontrar grandes concorrências com outras frutas, já que é a primeira fruta a ser ofertada no mercado, a partir de abril.

Em função das cultivares plantadas no Brasil, (de dia curto) e das condições climáticas brasileiras, o período mais propício para a produção de frutos de boa qualidade corresponde ao período de outono/inverno. Nessas épocas, as temperaturas são amenas e ocorre grande quantidade de dias ensolarados. Por outro lado, durante o período de verão, devido principalmente às altas temperaturas, as plantas passam a produzir estolhos, interrompendo a emissão de flores, e conseqüentemente, a produção de frutos (Resende et al., 1999). 
A fase de produção de mudas representa uma importante atividade econômica dentro da cadeia produtiva do morangueiro, uma vez que todo campo de produção de frutos necessita ser renovado anualmente e os gastos com a aquisição de mudas representam cerca de 45\% do custo fixo de produção (Agrianual, 2003).

No sistema convencional de produção de mudas de morangueiro estas são obtidas do cultivo de plantas matrizes diretamente no solo (Rebelo \& Balardin, 1993). De acordo com Minami ${ }^{1}$ as dificuldades de manejo fitossanitário, a facilidade de disseminação de pragas e doenças e o grande estresse causado por ocasião do transplante, estão entre os principais problemas que limitam o sistema convencional.

Tessarioli Neto (2001) descreve o sistema de produção de mudas de morangueiro em vasos suspensos, sob cultivo protegido, como uma alternativa viável aos principais problemas encontrados no sistema convencional.

A utilização de um sistema de produção de mudas sadias aliado a técnicas como a frigoconservação e vernalização em regiões aptas climaticamente, possibilitaria o cultivo do morangueiro em períodos de entressafra, aumentando a oferta do produto e podendo propiciar maiores ganhos pelos produtores. O objetivo desta tese foi estudar o sistema de produção de mudas de morangueiro (Fragaria x ananassa Duch.) em vasos suspensos e a aplicação das técnicas de frigoconservação e vernalização às mesmas visando a produção na entressafra.

\footnotetext{
${ }^{1}$ MINAMI, K. (USP/ESALQ. Departamento de Produção Vegetal) Comunicação pessoal, 2004.
} 


\section{REVISÃO DE LITERATURA}

\subsection{Panorama econômico da cultura}

Do total de morango produzido mundialmente em 1999/2000, o consumo global in natura representa 53,4\%; de morangos processados, 25\%; e de morangos congelados, 21,6\%. O volume de morangos congelados cresceu 15,2\% no período 1995-99, o de morangos processados 14,0\% e o consumo in natura de 12,8\%. Os Estados Unidos, primeiro produtor mundial, com 882 mil toneladas, em 1999, consumiu internamente quase toda sua produção, exportando somente 7,0\%, enquanto que a Espanha, segundo produtor, com 357 mil toneladas, exportou cerca de 61,6\%. Os principais importadores mundiais são: Canadá, Estados Unidos e Itália, sendo os volumes importados 52,5 mil, 37 mil e 27 mil toneladas, respectivamente (Sato \& Assumpção, 2002).

De acordo com os mesmos autores, dados obtidos junto às EMATERs indicam que em 1999 a produção brasileira chegou a 88,1 mil toneladas, mantendo-se ainda como primeiro produtor o Estado de Minas Gerais (33,16\%). O Estado de São Paulo passou a ser o segundo produtor (32,23\%), vindo a seguir o Rio Grande do Sul, que participou com 16,89\%, e o Espírito Santo, com 6,14\%. Participaram com menores volumes, Santa Catarina (2,37\%), Goiás (0,43\%) e Rio de Janeiro (0,35\%). Na Região Sudeste do Brasil em 1996 estava presente 61,1\% da produção nacional e na Região Sul, 32,9\%. Com menores volumes seguem-se a Região Centro-Oeste, com 4,6\%, a Região Nordeste, com 1,2\%, e a Região Norte, com 0,04\%. No Estado de São Paulo, segundo pólo produtor, a exploração comercial teve início nos municípios de Suzano e Itaquera, expandindo-se a seguir para Jundiaí e mais tarde para Piedade e Atibaia. Foi neste último município que a produção alcançou maior expressão, concentrando, atualmente, $24 \%$ do total plantado no Estado. 
Tabela 1. Produção de Morango no Estado de São Paulo, Instituto de Economia Agrícola e Coordenadoria de Assistência Técnica Integral 1997-2001

\begin{tabular}{lccc}
\hline Ano & Área (ha) & Produção (1.000cx.4kg) & Produção (t) \\
\hline 1997 & 817 & 6.208 & 24.832 \\
1998 & 899 & 7.430 & 29.720 \\
1999 & 911 & 7.105 & 28.420 \\
2000 & 672 & 5.418 & 21.672 \\
2001 & 707 & 5.901 & 23.607 \\
\hline
\end{tabular}

Dados coletados anualmente pelo IEA/CATI, órgãos da Secretaria de Agricultura e Abastecimento do Estado de São Paulo, indicam uma produção média no período de 1997-2001, de 25,6 mil toneladas, o que corresponde a cerca de 25\% da produção nacional (Tabela 1). No Estado, em 2001, o EDR de Sorocaba contribuiu com 47,6\% (11.240 toneladas), o de Campinas com 23,9\% (5.654 toneladas), o de Bragança Paulista com 18,8\% (4.434 toneladas) e o de Itapeva com 5,3\% (1.260 toneladas) (Sato \& Assumpção, 2002).

\subsection{Caracterização da planta}

O morangueiro, pertencente à família das Rosaceae, gênero Fragaria, é uma planta herbácea, rasteira, e embora tenha características de cultura perene persistindo no solo, é cultivada como cultura anual devido à questões fitossanitárias. Forma pequenas touceiras, que aumentam de tamanho à medida que a planta se desenvolve. A multiplicação se dá de forma vegetativa através da emissão de estolhos. Os estolhos são estruturas são muito flexíveis e se desenvolvem em contato com o solo, permitindo que a partir da roseta foliar existente em seus nós nasçam raízes que penetram no solo (a cada dois nós), e após a morte dos entrenós, dão origem a novas plantas independentes. Os estolhos se desenvolvem de forma particularmente intensa no mesmo período de crescimento das raízes, ou seja, após a frutificação e durante todo o verão. O cacho de flores do morango é uma série de ramos duplos produzindo uma flor na bifurcação de cada ramo. A flor na primeira bifurcação é denominada flor primária, as outras são secundárias, terciárias, etc. As flores primárias geralmente se abrem mais cedo e produzem os frutos maiores. A flor individual é esbranquiçada, com 1,0 a 1,5 cm 
de comprimento, geralmente composta de 5 a 10 sépalas verdes, 5 pétalas ovais, numerosos estiletes e 2 a 3 dúzias de estames. Inflorescências do tipo rácimo, completas e auto-férteis são predominantes nas cultivares comerciais (Ronque, 1998).

Os órgãos femininos, dispõem-se em espiral no centro da flor sobre uma intumescência ou receptáculo carnoso, que depois se tornará suculento e constituirá a parte comestível; os órgãos masculinos rodeiam aquele receptáculo. Nas cultivares plantados no Brasil as flores são hermafroditas, sendo a planta autopolinizada. A produção de sementes interessa somente aos melhoristas, não sendo utilizada pelos agricultores, uma vez que a propagação se dá de forma vegetativa. (Filgueira, 1982)

Camargo (1963) explica, que a parte comestível, carnosa e suculenta do morango é o receptáculo dos verdadeiros frutos, que são os aquênios, pequeninos, duros e superficiais. Entretanto, para fins comerciais, denomina-se fruto ao conjunto do receptáculo carnoso mais os aquênios.

\subsection{Desenvolvimento fisiológico}

O morangueiro é uma planta de clima temperado que em suas condições naturais de cultivo perde suas folhas durante o inverno, entrando em repouso vegetativo. Encontra-se desde o nível do mar até 3500m de altitude, e sob temperaturas que variam de $-10^{\circ} \mathrm{C}$ até regiões tropicais. Assim, o morangueiro é uma espécie que apresenta grande adaptabilidade. Apesar disto, os fatores ambientais exercem um papel fundamental no desenvolvimento e frutificação da planta (Camargo \& Passos, 1993).

Os primeiros estudos sobre a fisiologia do florescimento do morangueiro iniciaram-se com Darrow \& Waldo (1934) nos USA e Eguchi, citado por Guttridge (1969), no Japão. As revisões mais recentes sobre este assunto são de Larson (1994) e Taylor (2002).

A classificação do morangueiro é feita tradicionalmente com base no hábito de frutificação de cada cultivar. Atualmente, são consideradas três classes: plantas de dias curtos (DC), plantas de dias longos (DL) e plantas neutras (DN) ou insensíveis ao fotoperíodo. A grande maioria das cultivares é classificada como de dias curtos (DC), isto é, a indução floral ocorre com fotoperíodos inferiores a 14h. Entretanto, diversos 
estudos demonstraram que grande parte destas cultivares de DC exibe uma resposta facultativa, isto é, a indução floral ocorre mais ou menos continuamente e independente do comprimento do dia, desde que as temperaturas sejam inferiores a $15^{\circ} \mathrm{C}$. As cultivares DL são aquelas que florescem em condições de fotoperíodo maior que 14 horas de luz por dia. O terceiro grupo de morangueiros inclui cultivares referidas como de dias neutros (DN) ou indiferentes ao fotoperíodo, que florescem continuamente, independentemente do comprimento do dia. Embora a temperatura, também modifique a resposta fotoperiódica desse grupo de cultivares, elas são menos sensíveis às altas temperaturas do que as cultivares de DC (Larson, 1994). Esta multiplicidade de resposta ao florescimento se deve à natureza octaplóide da Fragaria x ananassa (Taylor, 2002).

As cultivares atualmente utilizados no Brasil se comportam como plantas de dias curtos, havendo a necessidade da diminuição do fotoperíodo e da temperatura para iniciar a floração e a frutificação (Passos, 1986). Em condições de temperaturas elevadas e de dias longos, as plantas emitem estolhos que geralmente a cada dois nós, emitem folhas e enraízam (Ronque, 1998).

Em geral, os fatores que induzem o crescimento vegetativo agem em detrimento do florescimento, com algumas exceções, como o cloromequat, que paralisa o desenvolvimento vegetativo, sem com isso induzir ao florescimento; e a ação dos dias longos em cultivares reflorescentes (DN), que favorecem o florescimento, sem paralisar o desenvolvimento vegetativo (Guttridge, 1969).

O florescimento e o crescimento vegetativo (principalmente a produção de estolhos) foram considerados processos antagônicos, nas cultivares de dias curtos (Jahn \& Danna, 1966; Guttridge, 1969), e o equilíbrio entre estes processos depende de estímulos promotores e inibidores de florescimento produzidos nas folhas e transmitidos às gemas (Nicoll \& Galletta, 1987).

De acordo com Galletta \& Bringhurst (1989), o florescimento e a frutificação do morangueiro dependem de uma série de passos de crescimento, que se estabelecem e desenvolvem na planta. É durante estes processos que se formam os locais com potencial de florescimento, denominados gemas. A conversão destas gemas da fase vegetativa para a fase reprodutiva, depende de uma série de fatores, genéticos e 
ambientais. Assim, o florescimento constitui-se basicamente de quatro processos: indução, iniciação, diferenciação e desenvolvimento final da flor (antese).

A indução ocorre nas folhas, que expostas às condições propícias, captam os sinais e transmitem ao meristema apical, levando à produção de um botão de flor (Mac Daniel, 1994). Vários fatores ambientais, incluindo o comprimento do dia e a temperatura, são conhecidos por estarem envolvidos na indução floral (Galletta \& Bringhurst , 1989).

A iniciação da flor é o conjunto de mudanças físicas e químicas que ocorrem na gema sob a recepção de estímulos florais produzidas nas folhas. Durante a transição para a floração o ápice do sistema caulinar vegetativo sofre uma seqüência de mudanças estruturais e fisiológicas e é transformado em um ápice reprodutivo. A diferenciação da flor é o desenvolvimento real dos órgãos florais dentro do botão. A antese é a expansão visível fora do botão. Consiste na fase final do processo de florescimento, quando os órgãos florais serão expostos possibilitando a polinização e, conseqüentemente, a fertilização. Na prática, a indução, a iniciação e a diferenciação, são referidos como iniciação do botão floral; a antese é o surgimento visível do botão. (Guttridge, 1985).

\subsubsection{Influências do ambiente no desenvolvimento do morangueiro}

São muitos os fatores que afetam a precocidade de produção do morangueiro e entre eles destacam-se as características próprias da cultivar, o clima, a época de plantio, o tipo e a qualidade da muda (Carbonari, 1978).

Ronque (1998), cita que os fatores climáticos de maior expressão que afetam a cultura são a temperatura e o fotoperiodismo, sendo que a temperatura exerce maior influência. Fatores como estiagem, chuvas excessivas, alta e baixa umidade e a qualidade e intensidade da luz, também exercem influência, mas em menor grau de importância. 


\section{a. Temperatura}

A temperatura é o fator ambiental de maior importância para o morangueiro, pois afeta diretamente a frutificação e o desenvolvimento vegetativo da planta. A frutificação é grandemente prejudicada nos trópicos, onde temperaturas mais elevadas fazem com que o morangueiro continue na fase vegetativa, produzindo estolhos indefinidamente. Além disso, elevações da temperatura durante a fase de produção de frutos, tornam estes pouco firmes, ácidos e pobres em sabor (Ronque, 1998).

O crescimento da coroa e das folhas ocorre numa faixa de temperatura ampla, quase desde o ponto de congelamento até $35^{\circ} \mathrm{C}$ (Galleta \& Bringhurst, 1989), sendo mais rápido à medida que a temperatura e o fotoperíodo aumentam, até um certo ponto. O crescimento ótimo da folha ocorre entre 20 e $26^{\circ} \mathrm{C}$ (Darrow, 1936; Hartmann, 1947) e pode ser incrementado através da irrigação e “mulching” (cobertura do solo), pois este último procedimento pode elevar a temperatura do solo até a $20 \mathrm{~cm}$ de profundidade. A coroa pode ser injuriada quando exposta a temperaturas de -3,9 a $6,6^{\circ} \mathrm{C}$, morrendo entre $-9,4$ e $-12,2^{\circ} \mathrm{C}$.

A dormência do morangueiro, é ocasionada por dias curtos e baixas temperaturas. Pouco antes da planta entrar em dormência, ocorre uma paralisação no crescimento e uma produção excessiva de carboidratos, os quais são estocados em vários órgãos (coroa, pecíolos e raízes primárias), principalmente na forma de amido. Esse amido é hidrolisado durante os períodos mais frios, visto que os carboidratos formados baixam o ponto de congelamento do suco celular, fazendo com que a planta resista ao estresse térmico (Taylor, 2002).

O morangueiro apresenta ainda latência relativa, isto é, o período o qual acumula uma certa quantidade de horas de frio para que seja capaz de produzir um número abundante de flores e frutos. O número de horas necessárias para se alcançar desenvolvimento e bons rendimentos é diferente para cada cultivar. Em geral, as exigências vão de 380 a 700 horas acumuladas de temperaturas entre $2^{\circ} \mathrm{C}$ e $7^{\circ} \mathrm{C}$ (Ronque, 1998).

Guttridge (1985) cita, que para o florescimento de cultivares de dias curtos, os seguintes intervalos de temperatura foram considerados críticos: 15 a $21^{\circ} \mathrm{C}$ 
(Hartman, 1947), 10 a $14^{\circ} \mathrm{C}$ (Went, 1957), 9 a $17^{\circ} \mathrm{C}$ (Ito e Saito, 1962) e 12 a $18^{\circ} \mathrm{C}$ (Heide, 1977). Goppo et al. (1997) estudando o comportamento de diversas cultivares de morangueiro, constataram que a precocidade de produção e a maturação é variável com a cultivar; isto explica a existência das diferentes.

\section{b. Fotoperíodo}

A luz é um importante fator ambiental na regulagem do crescimento e do desenvolvimento do morangueiro. O incremento no nível de radiação resulta, normalmente, em aumento no peso da matéria seca da coroa, raíz e folha, na fixação e tamanho dos frutos e na formação e peso da matéria seca dos estolões (Larson, 1994).

Dennis et al. (1970) consideraram que o fator mais importante que afetou o comportamento do morangueiro foi o fotoperíodo. Os efeitos da intensidade da radiação foram principalmente quantitativos, com a maior intensidade favorecendo a floração ou a produção de estolões, dependendo do cultivar.

As cultivares de morangueiro são freqüentemente classificadas baseandose nas respostas fotoperiódicas, particularmente em relação à indução floral. O tamanho da folha, o comprimento do pecíolo e o desenvolvimento do estolão também são altamente sensíveis ao fotoperíodo e a temperatura (Larson, 1994). Em muitos cultivares, há uma forte interação entre fotoperíodo e temperatura, com a temperatura modificando as respostas fotoperiódicas (Darrow, 1936). Embora as respostas vegetativa e reprodutiva do morangueiro para fotoperíodo e temperatura sejam bem documentadas, os processos fisiológicos que regulam estas respostas ainda não foram perfeitamente esclarecidos (Larson, 1994).

As cultivares de morangueiro que se comportam como plantas de dia curto requerem comprimentos de dias menores que 14 horas ou temperaturas menores que $15^{\circ} \mathrm{C}$ para indução floral. O fotoperíodo ótimo, encontrado ficou entre 8 e 11 horas de luz/dia (Bortowick e Parker, 1953; Austin, 1961; Ito e Saito, 1962; Bernoit, 1975; todos citados por Baldini, 1997). Se o fotoperíodo for muito curto, pode ocorrer uma carência de assimilados, com o aborto das inflorescências jovens, conforme citações de Guttridge (1985). 


\section{c. Inter-relação temperatura $x$ fotoperíodo}

Para que ocorra a indução floral, a temperatura e o fotoperíodo devem permanecer favoráveis por um espaço de tempo suficiente, denominado ciclo indutivo. Diversos autores concluíram que o número mínimo de ciclos de dia curto para induzir o florescimento, nas cultivares octaplóides, está normalmente entre 7 a 14 dias, podendo chegar a 23 dias, conforme citações de Guttridge (1985), devendo ser determinada para cada cultivar.

O período de temperatura indutiva necessário para o florescimento foi estudado por Morishita e Yamakama (1994), citados por Baldini (1997), em seis cultivares. Verificaram que, a 8 horas de luz/dia e $12^{\circ} \mathrm{C}$, o período crítico necessário foi de 10 a 15 dias para as cultivares 'Nyoko', 'Toyonoha' e 'Harunoka', 15 a 20 dias para 'Haruyoi' e mais de 20 dias para 'Chiyoda' e 'Yachiyo'. As plantas que não receberam ciclo indutivo suficiente floresceram aproximadamente ao mesmo tempo em que as testemunhas (sem tratamento indutivo).

Yanagi \& Oda (1992) estudaram o efeito do fotoperiodo e de tratamentos

com baixas temperaturas em cultivares não reflorescentes, reflorescentes e intermediários. Em um primeiro experimento utilizou-se a temperatura de $20^{\circ} \mathrm{C}$,com duração do período iluminado de 8 a 16 horas, durante 30 dias. As cultivares reflorescentes e intermediárias formaram flores em ambos os fotoperíodos, enquanto que as cultivares não reflorescentes só formaram flores em fotoperíodos de dias curtos. Em um segundo tratamento todas as cultivares foram submetidas a distintos tratamentos de baixas temperaturas e depois colocadas a $20^{\circ} \mathrm{C}$, mas com um período de iluminação de 16 horas por dia, durante quatro meses. Foi constatado que os tratamentos de baixas temperaturas não tinham efeito algum nas cultivares reflorescentes. Entretanto, nas cultivares não reflorescentes e nas intermediárias, a produção de inflorescências era menor à medida que se aumentava a duração dos tratamentos com baixas temperaturas.

Estudando a interrelação temperatura-fotoperiodismo na produção de botões florais, Darrow (1936) pode demonstrar que, independente da temperatura, dias curtos favorecem a produção de flores e inibem a emissão de estolhos. Van Den 
Muyzenberg (1942), citado por Darrow (1966), encontrou que entre 6 e 14 dias de fotoperíodo curto (6 a 12 horas), são necessários para a iniciação floral.

Foi obtido o florescimento em temperaturas abaixo de $12-14^{\circ} \mathrm{C}$, não se levando em consideração o comprimento do dia (Darrow, 1936). Mantendo-se a temperatura entre 17 e $24^{\circ} \mathrm{C}$ foi necessário um fotoperíodo menor que 12 horas para o florescimento (Ito e Saito, 1962), conforme citações de Durner et al. (1984).

\subsection{Sistemas de produção de mudas}

\subsubsection{Sistema Convencional}

De acordo com Minami ${ }^{1}$, a produção convencional de mudas no estado de São Paulo visando atender os produtores de frutos está baseada atualmente em três situações distintas.

a.) Os produtores de mudas adquirem as plantas matrizes certificadas e isentas de pragas e doenças do Instituto Agronômico de Campinas, e a partir dai multiplicam estas mudas, revendendo para os produtores de frutos.

b.) Os produtores de mudas adquirem as plantas matrizes obtidas através de cultura de tecido em firmas especializadas e multiplicam estas mudas, revendendo para os produtores de frutos.

c.) O próprio produtor de frutos produz suas mudas a partir de algumas plantas produtoras de frutos da safra anterior.

Em todos os casos a produção de mudas é feita em campo aberto e diretamente no solo. As plantas matrizes, são cultivadas em canteiros no espaçamento entre 1 a $2 \mathrm{~m}$ entre plantas, onde emitem os estolhos que ao entrarem em contato com o solo enraízam, produzindo novas mudas. Estas novas mudas por sua vez emitem novos estolhos que irão originar mais mudas, preenchendo completamente os canteiros (Figura 1). Na época de plantio, as mudas são arrancadas e comercializadas na forma de raiz nua (Figura 2). A produtividade gira em torno de 200 mudas por matriz, com aproveitamento final de cerca de 80\% (Rebelo \& Balardin, 1993).

\footnotetext{
${ }^{1}$ MINAMI, K. (USP/ESALQ. Departamento de Produção Vegetal) Comunicação pessoal, 2004.
} 


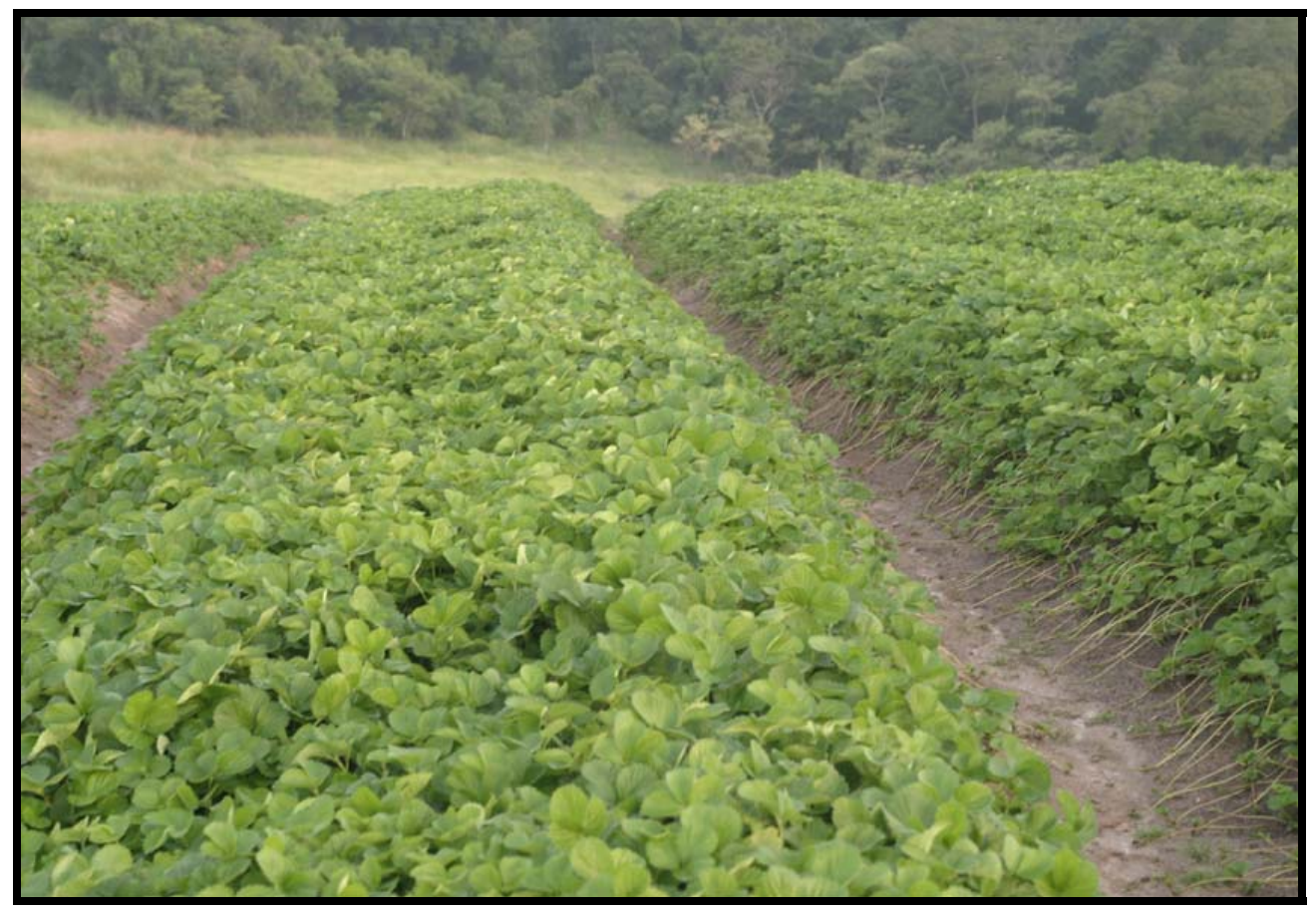

Figura 1 - Canteiro de produção de mudas de morangueiro em sistema convencional. Jarinú/SP, 2004

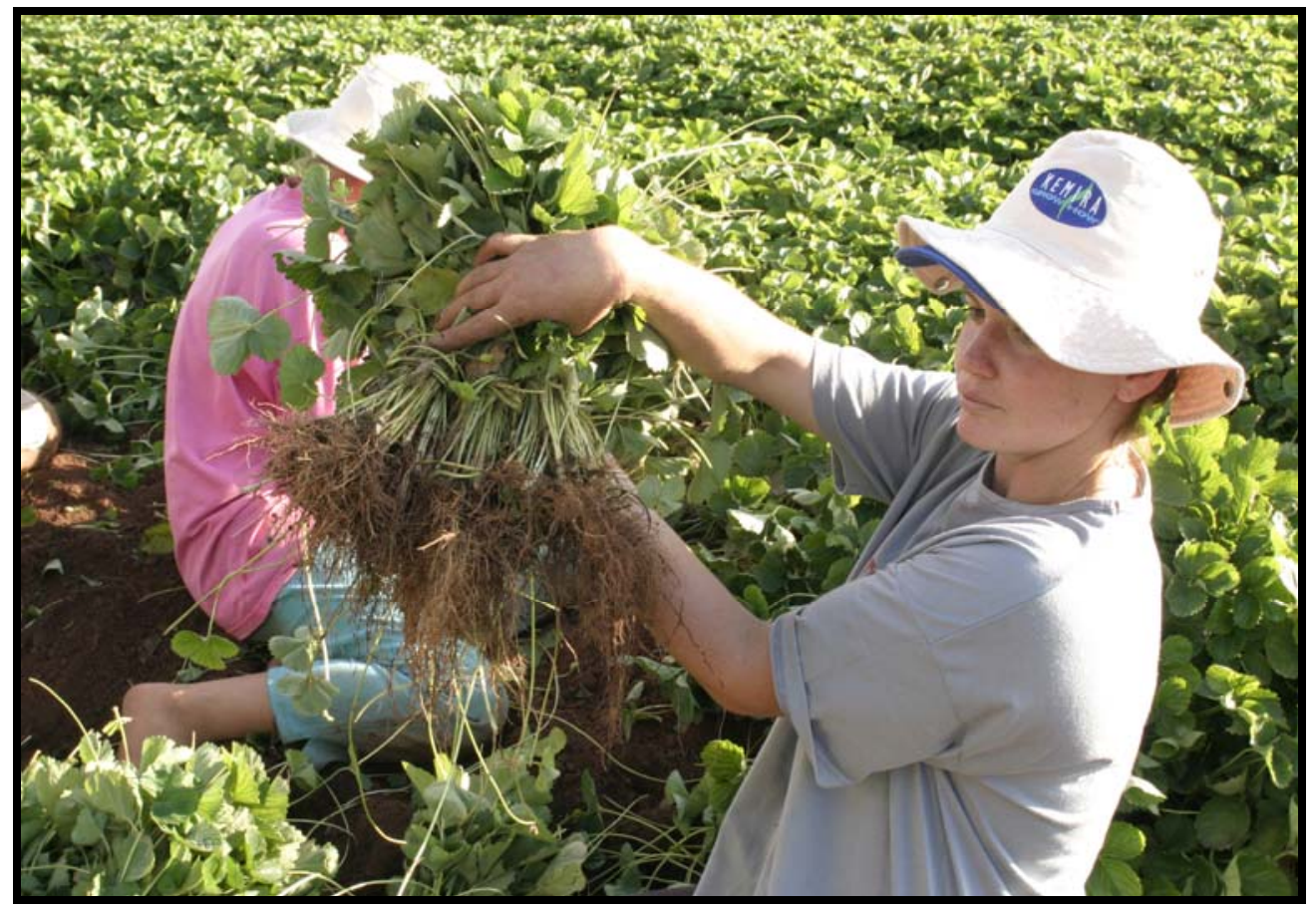

Figura 2 - Coleta de mudas de morangueiro em sistema convencional. Detalhe das raízes nuas. Jarinú/SP, 2004 
De acordo com Assis (1999), devido às características de cultivo e a susceptibilidade do morangueiro a inúmeras pragas e doenças que afetam as raízes e a parte aérea, o seu controle deve ser preventivo e sistemático. A manutenção de um viveiro convencional em bom estado fitossanitário é dificultada pelo longo ciclo e principalmente pelas condições adversas ao cultivo do morangueiro (chuvas intensas e altas temperaturas), comuns nos meses de verão. Nessa época, que coincide com o final do ciclo, ocorre a sobreposição e o entrelaçamento das mudas de estolão formando um microclima bastante favorável ao desenvolvimento de doenças, tornando difícil a aplicação ou mesmo reduzindo a eficiência dos defensivos.

De acordo com Scarpare Filho (1995), a exportação de material orgânico do local de produção de mudas para o local definitivo de cultivo representa um enorme potencial para disseminação de pragas e doenças.

\subsubsection{Sistema em vasos suspensos}

O sistema de produção de mudas em vasos suspensos apresenta-se como uma interessante alternativa aos diversos problemas apresentados pelo sistema convencional. Neste sistema as plantas matrizes são cultivadas sob cultivo protegido em vasos mantidos sobre bancada, de modo que os estolhos não entram em contato com o solo e, conseqüentemente, não enraízem (Figura 3). A produção de mudas de morangueiro em vasos suspensos, sob cultivo protegido é tecnicamente viável e, apesar da quantidade de mudas totais produzidas por planta matriz ser inferior quando comparada ao sistema convencional no solo, a produtividade por área de cultivo é maior, já que o cultivo é mais adensado (Tessarioli Neto, 2001).

De acordo com o mesmo autor, as mudas produzidas no sistema de vasos suspensos sob cultivo protegido apresentam melhores qualidades fitossanitárias, eliminando-se praticamente o risco de disseminação de pragas e patógenos para o local de cultivo através das mudas. Além disso, estas mudas apresentam maiores teores de carboidratos totais, quando comparadas com mudas formadas no sistema convencional, conferindo maior qualidade fisiológica a estas. 


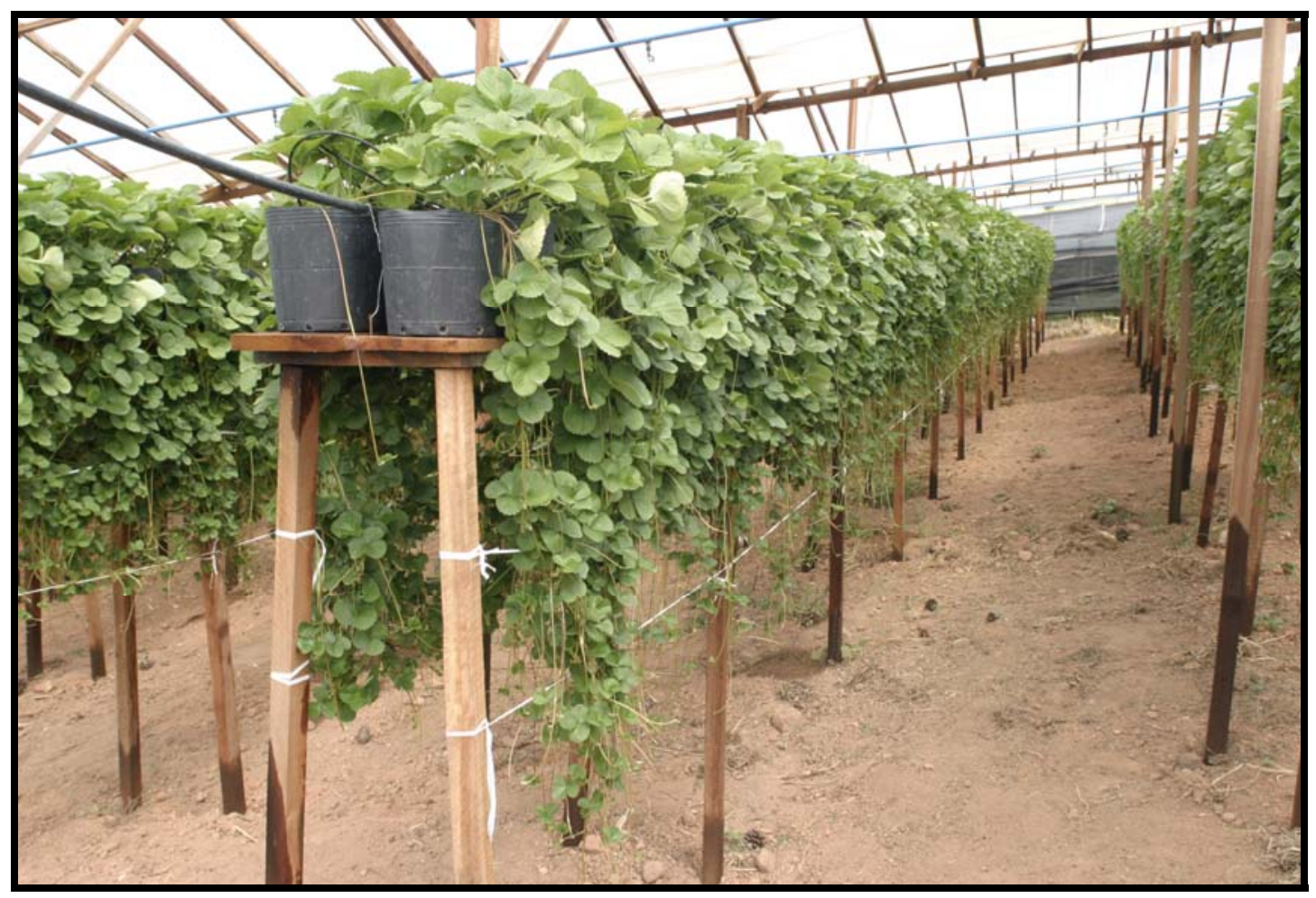

Figura 3 - Produção de mudas de morangueiro em vasos suspensos baseado no sistema desenvolvido por Tessarioli Neto (2001). Jarinú/SP, 2004

Lieten (2002) cita como vantagens do cultivo de mudas em vasos: o menor risco de infecção por doenças de raízes, melhor controle da nutrição das plantas, facilidade de transplante das mudas, sem causar injúrias nas raízes.

Sugiura (1995) recomenda o uso de bancadas altas para multiplicação de plantas sadias de morangueiro, como forma de evitar a infecção por doenças de solo, e de estufas a prova de afídeos, para evitar a contaminação por vírus. Na França, o CIREF (Centre Interrégional de Recherche et d’Experimentation de la Fraise) desenvolveu e patenteou uma técnica denominada "Fraisimotte", que consiste na obtenção de mudas através de matrizes cultivadas sem uso de solo, isto é, em substratos, e transplantadas em “plugs”. Este sistema visa a obtenção de mudas para o cultivo em sacolas, com redução de 50\% nos custos de plantio (CIREF, 1998). 


\subsection{Frigoconservação de mudas}

De acordo com Lieten (2002) a frigoconservação de mudas de morangueiro possibilita que muitos produtores europeus prolonguem o período produtivo. Uma produção satisfatória pode ser obtida por tais mudas depois do pico de

produção, quando os preços pagos aos produtores são mais elevados. Segundo Fachinello (1999), o emprego das mudas frigoconservadas está ligado principalmente ao cultivo protegido e hidropônico.

Duarte Filho et al. (1999) citam como vantagens do uso desse tipo de muda a possibilidade de aumentar o período de oferta de mudas aptas ao plantio, no momento mais oportuno, conforme o clima e cultivares. Essa técnica permite ainda, quando necessário, satisfazer as exigências de horas de frio destas mudas.

Na Argentina as mudas destinadas à frigoconservação são produzidas nas zonas mais frias (Mendoza e H. Ascaulir) em cultivo protegido, visando a produção de morangos de 15 de janeiro a 15 de março, época de colheita considerada média. Para isso, estas mudas devem entrar em plena dormência no campo (julho-agosto) e ser armazenada por seis meses a $-2^{\circ} \mathrm{C}$. Para plantio de dezembro a fevereiro são utilizadas mudas produzidas nos USA e Europa, frigoconservadas. Do verão ao início do outono (janeiro a abril) Buenos Aires é a única região que produz morangos (Rodriguez, 1997a e 1997b). O plantio é feito em novembro com mudas frigoconservadas, e as cultivares utilizadas são reflorescentes. O rendimento anual varia de 200 a 600 g/planta, de acordo com a cultivar, origem e forma de condução (Fernández, 1997).

Segundo Branzanti (1989), essa técnica pode ser dividida em quatro etapas: obtenção das mudas para conservação, tratamento das mudas, embalagem das mudas e conservação em câmara fria.

\subsubsection{Obtenção das mudas para frigoconservação}

Nos países onde é comum a frigoconservação de mudas, essas são produzidas diretamente no solo em canteiros. As mudas são arrancadas do viveiro quando se encontram no estádio de latência. Nessa condição o seu conteúdo de substâncias de reservas é adequado, o que favorece sua conservação (Branzanti, 1989). 
A utilização dessas plantas em cultivo protegido faz com que ocorra o seu florescimento com um mês, podendo dessa forma, obterem-se bons rendimentos, assim como produções em qualquer época do ano.

As condições físicas das plantas no arranquio são determinantes para o sucesso de uma longa conservação. As plantas devem ser expostas a um mínimo de horas de frio de acordo com as características de cada cultivar e terem um certo nível de dormência antes de serem armazenadas por longos períodos. Estudos demonstraram que somente plantas que acumularam reservas suficientes podem ser armazenadas (Lieten, 1996). O mesmo autor cita que os melhores armazenamentos e posteriores produções são obtidos com mudas que permanecem encanteiradas recebendo entre 500 a 800 horas de temperaturas menores que $7^{\circ} \mathrm{C}$ e apresentam teores entre 100 a $140 \mathrm{mg}$ de açúcares totais por grama de matéria seca. Por ocasião do arranquio das mudas, clima seco e temperaturas baixas $\left(1\right.$ a $\left.7^{\circ} \mathrm{C}\right)$ favorecem o processo de armazenagem.

De acordo com Tessarioli Neto (2001), as mudas de morangueiro produzidas em sistema de vasos suspensos apresentam maiores teores de carboidratos em seus rizomas quando comparadas com mudas produzidas diretamente no solo. $\mathrm{O}$ autor cita que uma das possíveis explicações para este comportamento está no fato das mudas produzidas em vasos suspensos não desenvolverem raízes, e desta forma concentrarem os fotossintetizados. Estas mudas apresentam ainda melhores qualidades fitossanitárias quando comparadas com mudas produzidas convencionalmente no solo.

\subsubsection{Tratamento das mudas}

Após o arranquio, é feita uma limpeza, eliminando-se os resíduos de solo aderidos às raízes. A seguir, cortam-se as folhas, cuja presença dificulta a conservação das mudas além de aumentar o volume por elas ocupado. Já o sistema radicular deve ser mantido intacto o máximo possível, para aproveitar melhor as substâncias de reserva que ele contém (Branzanti, 1989).

Uma limpeza mal feita aumenta o risco do desenvolvimento de mofo. Deve-se proceder a máxima retirada de solo das raízes sem contudo danifica-las. 
Recomenda-se ainda o tratamento preventivo pela imersão das plantas em uma solução com fungicida (Anderson \& Guttridge, 1975).

\subsubsection{Classificação e embalagem das mudas}

Recomenda-se que as mudas sejam empacotadas de acordo com as dimensões do rizoma. Alguns pesquisadores estabelecem uma relação positiva entre o diâmetro do rizoma e a capacidade produtiva da muda (Faby, 1996). Assim, as mudas são normalmente classificadas por estes pesquisadores em três categorias: $\mathrm{A}+$, com diâmetro maior que 15mm, estas mudas produzem em média 3 inflorescências, que dão origem aproximadamente a 30 frutos de bom tamanho; A, mudas com 12 a $15 \mathrm{~mm}$ de diâmetro do rizoma, produzem entre 1 a 2 inflorescências que dão origem entre 10 e 20 frutos; e B, mudas com diâmetro menores que $12 \mathrm{~mm}$ que são normalmente utilizadas como matrizes para outras mudas e não para produção de frutos.

Segundo Carbonari (1978), estolhos mais velhos ou maiores produzem mais frutos. Robertson (1955) constatou que eles produziam primórdios florais mais precocemente. Jahn e Danna (1970) afirmam que mudas mais desenvolvidas asseguram um maior número de botões florais.

Santos (1987), estudando a influência do tamanho das mudas na produção de morangueiros, concluiu que para a cultivar Lassen, comparando-se mudas média e grandes não houve diferença de precocidade, produção total e no primeiro terço de colheita. Entretanto, as produções das mudas médias no segundo terço de colheita foram inferiores e, no terceiro terço, superiores às das grandes. As mudas pequenas tiveram além de produções inferiores, início de colheita retardado em 10 dias.

Ortigoza (1999) utilizou como parâmetros o diâmetro da coroa (mm), a altura da parte aérea e número de folhas para classificação das mudas produzidas (tabela 2). 
Tabela 2. Parâmetros e categorias adotadas para avaliação das mudas coletadas por Ortigoza, Piracicaba, 1999

\begin{tabular}{|c|c|c|c|c|}
\hline \multirow[t]{2}{*}{ Parâmetros } & \multicolumn{4}{|c|}{ Categorias } \\
\hline & Extra & Tipo 1 & Tipo 2 & Descarte \\
\hline Diâmetro da coroa (mm) & $>12$ & $12-9$ & $9-5$ & $<5$ \\
\hline Altura da parte aérea (mm) & $>160$ & $160-130$ & $130-70$ & $<70$ \\
\hline Número de folhas & $>7$ & $7-5$ & $5-2$ & $<2$ \\
\hline
\end{tabular}

A embalagem das mudas é feita em sacos plásticos transparentes com espessura entre 0,03 - 0,06 mm. Deve-se tomar cuidado para retirar o ar do interior do saco. A seguir faz-se uma dobra tripla na boca do saco, grampeando (Branzanti, 1989). Alguns pesquisadores recomendam a utilização de sacos plásticos com espessura de 0,07 mm, entretanto não existem diferenças quanto à armazenagem, vigor e produção de frutos para plantas armazenadas em sacos plásticos com espessura entre 0,02 e 0,07 mm. Não devem ser utilizados sacos plásticos micro-perfurados a fim de evitar a desidratação das plantas (Linden, 1964).

Segundo Rodríguez (1997) a utilização de plásticos com espessura superior a 70 micra impede as trocas gasosas, provocando o aumento da concentração de $\mathrm{CO}_{2}$ dentro do saco de armazenamento.

\subsubsection{Conservação em câmara fria}

A temperatura da câmara fria é o fator decisivo para uma boa conservação por períodos prolongados. Para armazenamentos rápidos (3 a 4 semanas) são aceitas temperaturas entre 0 a $1^{\circ} \mathrm{C}$. Entretanto, poderá se desenvolver mofo e as plantas poderão se desidratar caso o armazenamento se estenda por um período muito longo (Anderson \& Guttridge, 1975).

Para longos períodos de armazenamento a temperatura deve ser mantida na faixa de -1 a $-2^{\circ} \mathrm{C}$, a qual bloqueia as atividades vegetativas e não causa danos aos tecidos das plantas (Branzanti, 1989). Temperaturas menores que $-3^{\circ} \mathrm{C}$ podem causar 
injurias nos tecidos dos rizomas, reduzindo o vigor e a produção (Lieten \& Goffings, 1996).

Okasha \& Ragab (1992) estudaram a influência do armazenamento dos estolhos em diferentes regimes (4, 6 e 8 meses a $-2^{\circ} \mathrm{C}$ ) para as cultivares Selva (dia neutro) e Pajaro (não reflorescente). Constataram que a cultivar Selva foi afetada negativamente em todos os tratamentos estudados, uma vez que a temperatura de armazenamento de $-2^{\circ}$ foi demasiadamente baixa para a sobrevivência das mudas. Além disso, foi verificado que o aumento do período de armazenamento se correlacionava negativamente com a diferenciação floral. A produção precoce das plantas armazenadas durante quatro meses era mais elevada que as armazenadas durante oito meses, se bem que a produção total correspondente a última era maior.

Biggy (2000) estudando a qualidade de plantas frigoconservadas das cultivares Gariguette, Elsanta, Darsetect, Cigaline, Ciloé e Cirene, relata que no caso da cultivar Gariguette houve o desenvolvimento de necroses após a frigoconservação. O autor explica este fato devido ao gelo ou a natureza fisiológica inerente a própria cultivar.

\subsection{Vernalização de mudas}

A vernalização das mudas consiste em fornecer às plantas artificialmente condições de temperatura para que ocorra a diferenciação das gemas em botões florais, na época em que tais condições não ocorrem naturalmente (Baldin, 1997).

Brandão Filho et al. (1989) estudando o efeito da vernalização por 10, 15 e 20 dias, à temperatura de $10^{\circ} \mathrm{C}$, na cultivar de morango AGF-80, verificaram que a vernalização teve efeito significativo e que o aumento do tempo de vernalização promoveu a precocidade no aparecimento de botões florais diferenciados, botões visíveis e flores abertas.

Baldin (1997) estudando a vernalização de mudas de morangueiro das cultivares Campinas e Tonoyoka submetidas à temperatura entre $8-10^{\circ} \mathrm{C}$ e 8 horas de luz/dia, durante 20 dias, constatou uma sobrevivência de 98,1\% aos 10 dias do transplante para as duas cultivares, e 92,6 e 96,3\% aos 21 dias para as cultivares 
Campinas e Toyonoka, respectivamente. A pesquisadora cita ainda, que a vernalização das mudas estimulou a emissão de botões florais, sendo que 62,9 e 61,1\% das plantas das cultivares Campinas e Toyonoka apresentaram inflorescência aos 40 dias do transplante, respectivamente. A vernalização das mudas propiciou a antecipação da colheita, sendo que a produção de frutos (peso e número) foi superior nas quatro primeiras semanas, quando comparado com tratamentos que não sofreram vernalização.

A influência da vernalização difere de cultivar para cultivar. Vários autores verificaram que as plantas vernalizadas geralmente apresentam-se mais vigorosas e com maior desenvolvimento vegetativo, apresentando produções maiores com florescimento precoce (Netherlands, 1975; Matsumoto, 1986; Economides \& Gregorion, 1990 e Wijsmuller, 1988; todos citados por Resende 1992).

\subsection{Plantas de morangueiro com coroas múltiplas}

No início da década de 70 a Holanda começou a desenvolver um novo sistema produtivo denominado “waiting bed plantas system”. No final da década de 80 a produção de morangos na Holanda nos meses de agosto a outubro (verão ao início do outono) era feita com mudas desse sistema em 75\% da área , de acordo com Dijkstra (1989) citado por Lopez Galarza et al. (1996).

Para se obter tais mudas era feito o enviveiramento de engrossamento, na densidade de 8-16 plantas $/ \mathrm{m}^{2}$, separadas por 0,25 - 0,35m. Eram eliminadas os estolões e flores para as mudas acumulassem o máximo de reservas e formassem o maior número de coroas. Este tipo de muda visa atender a demanda na entressafra (verão), quando normalmente não se encontram mudas disponíveis para o plantio. Cultivadas em locais de clima ameno chegam a produzir razoavelmente, entretanto florescem apenas uma única vez. Portanto, quanto mais desenvolvidas as mudas estiverem e com o maior número de coroas, mais potencialidade de produção elas terão.

Lopez Galarza et al (1996) relatam que as mudas de coroas múltiplas tem menor adaptação ao plantio em zonas com temperaturas mais elevadas. Dijkstra (1989) citado por esses autores relata que a utilização dessas mudas na Holanda, no verão, tem

menor produção e menor tamanho dos frutos como conseqüência das elevadas 
temperaturas na fase de implantação da cultura quando comparadas com plantios na época convencional.

Segundo Passos ${ }^{1}$, nos últimos anos, alguns produtores do sul de Minas Gerais, tem feito o plantio antecipado em janeiro utilizando sobras de mudas do ano anterior. Estas mudas nada mais são que plantas de coroas múltiplas, que permaneceram no campo de um ano para outro e que podem proporcionar colheitas antecipadas quando cultivadas em locais de clima mais ameno.

\footnotetext{
${ }^{1}$ PASSOS, F.A . (Instituto Agronômico de Campinas) Comunicação pessoal, 2004.
} 


\section{TEORES DE CARBOIDRATOS TOTAIS E SOBREVIVÊNCIA DE MUDAS DE MORANGUEIRO PRODUZIDAS EM SISTEMA CONVENCIONAL E EM VASOS SUSPENSOS}

\section{Resumo}

O objetivo desse experimento foi comparar o sistema de produção de mudas de morangueiro convencional com o de produção em vasos suspensos. Para isso foram avaliados a matéria seca, os teores de carboidratos nas mudas e a percentagem de sobrevivência das mesmas após o transplante para local definitivo. Foram utilizadas as cultivares IAC-Campinas, Pelican e IAC-Guarani. O delineamento experimental foi em esquema fatorial 3x2 (três cultivares e dois sistemas de produção de mudas), em blocos ao acaso, com três repetições. Os dados obtidos foram submetidos a análise de variância através do teste $\mathrm{F}$ e as médias dos tratamentos foram comparadas entre si pelo teste de Tukey ao nível de 5\% de probabilidade. As mudas produzidas em vasos suspensos apresentaram maior percentagem de sobrevivência e maiores teores de carboidratos totais. Os resultados foram semelhantes para as três cultivares.

Palavras-chave: Fragaria x ananassa Duch., cultivares de morangueiro, produção de mudas. 


\section{Carbohydrates content and survival of strawberry runners produced in conventional and suspended pots systems}

\section{Summary}

It was developed this experiment in order to compare the conventional strawberry runners production system with the runner production system in suspended pots. For that, it was measured the dry matter and carbohydrates contents in runners and the survival percentage when the runner were transplanted to field production areas. The cultivars IAC-Campinas, Pelican and IAC-Guarani were used, in an experimental design of factorial arrangement 3x2 (three cultivars and two runners production systems), three replications. The data were submitted to analysis of variance through $\mathrm{F}$ test and treatment means were compared by Tukey test at $5 \%$ of probability. The runners produced by the system of suspended pots accumulated higher amount of total carbohydrates and the plant survival rate. The results were similar for the three cultivars.

Keywords: Fragaria x ananassa Duch., strawberry cultivars, plant produciton

\subsection{INTRODUÇÃO}

Embora o morangueiro seja fisiologicamente uma espécie perene, os problemas fitossanitários e o próprio desenvolvimento fisiológico da planta limitam que estas sejam mantidas no campo de uma safra para outra, tornando necessário renovar anualmente todo campo de produção de frutos (Filgueira, 1982). As plantas são propagadas comercialmente com a utilização de mudas de estolho, produzidas por plantas matrizes, sendo que o número de mudas produzidas pode variar conforme a cultivar, região de plantio e as condições de cultivo (Passos et al., 1999).

De acordo com Assis (1999), o principal cuidado a ser tomado na fase de produção de mudas é a prevenção da contaminação por pragas e doenças, que podem, posteriormente, comprometer as lavouras de produção de frutos.

Além do aspecto fitossanitário, fisiologicamente as mudas devem apresentar potencial produtivo capaz de proporcionar uma alta taxa de sobrevivência e 
um rápido desenvolvimento inicial das plantas no campo. Para as condições de cultivo em clima temperado, as temperaturas amenas e os dias curtos do início do inverno propiciam o acúmulo de reservas na forma de carboidratos e a dormência das plantas de morangueiro durante o inverno. Na primavera, essas reservas são utilizadas pelas plantas para o início do desenvolvimento vegetativo e reprodutivo. Assim, quanto maior a quantidade de reservas acumuladas, maior será o potencial produtivo das mudas (Rice, 1990).

De acordo com Tessarioli Neto (2001), as mudas de morangueiro produzidas em sistema de vasos suspensos apresentam maiores teores de carboidratos em seus rizomas quando comparadas com mudas produzidas diretamente no solo. $\mathrm{O}$ autor explica que uma das possíveis explicações para este comportamento está no fato das mudas produzidas em vasos suspensos não desenvolverem raízes, e desta forma concentrarem os fotossintetizados.

No sistema convencional a produção de mudas é feita em campo aberto e diretamente no solo. Plantas matrizes selecionadas isentas de pragas e doenças, são plantadas em canteiros no espaçamento entre 1 a $2 \mathrm{~m}$ entre plantas, onde emitem os estolhos que ao entrarem em contato com o solo enraízam, produzindo novas mudas. Estas novas mudas por sua vez emitem novos estolhos que irão originar mais mudas, preenchendo completamente os canteiros. Na época de plantio, as mudas são arrancadas e comercializadas na forma de raíz nua. A produtividade gira em torno de 200 mudas por matriz, com aproveitamento final de cerca de 80\% (Rebelo \& Balardin, 1993).

De acordo com Assis (1999), devido às características de cultivo e a susceptibilidade do morangueiro a inúmeras pragas e doenças que afetam as raízes e a parte aérea, o seu controle deve ser basicamente preventivo e sistemático. A manutenção de um viveiro convencional em bom estado fitossanitário é dificultada pelo longo ciclo e principalmente pelas condições adversas ao cultivo do morangueiro (chuvas intensas e altas temperaturas), comuns nos meses de verão. Nessa época, que coincide com o final do ciclo, ocorre a sobreposição e o entrelaçamento das mudas de estolão formando um microclima bastante favorável ao desenvolvimento de doenças, tornando difícil a aplicação ou mesmo reduzindo a eficiência dos defensivos. 
No sistema de vasos suspensos (Tessarioli Neto, 2001) as plantas matrizes são cultivadas sob cultivo protegido em vasos mantidos sobre bancada, de modo que os estolhos não entram em contato com o solo e conseqüentemente não enraízam. Segundo o mesmo autor, a produção de mudas de morangueiro em vasos suspensos, sob cultivo protegido é tecnicamente viável e, apesar da quantidade de mudas totais produzidas por planta matriz ser inferior quando comparada ao sistema convencional no solo, a produtividade por área de cultivo é maior, já que o cultivo é mais adensado.

A utilização de um sistema adequado para a condução das plantas matrizes fornecedoras de mudas é de fundamental importância, tanto a fim de favorecer a quantidade de mudas produzidas, como a qualidade destas. O objetivo deste ensaio foi comparar as mudas de morangueiro produzidas no sistema convencional com as mudas produzidas no sistema de vasos suspensos quanto ao acúmulo de carboidratos totais e sobrevivência inicial das mesmas.

\subsection{MATERIAL E MÉTODOS}

O experimento foi desenvolvido no período de 13/11/2000 a 26/05/2001 no Depto. de Produção Vegetal da ESALQ/USP em Piracicaba/SP.

\subsubsection{Cultivares e tratamentos}

As cultivares utilizadas foram: IAC-Campinas, IAC-Guarani e Pelican, adquiridas da empresa Multiplanta e conduzidas em dois sistemas, sendo cada um deles considerado um tratamento.

a.) Sistema de vasos suspensos: as matrizes foram cultivadas em vasos com a capacidade de 5,0 litros preenchidos com uma mistura de terra tratada com brometo de metila e substrato comercial Geomax, na proporção de 1:1. Os vasos foram mantidos em suportes a 1,50 m de altura, no espaçamento de $40 \mathrm{~cm}$ entre vasos, dentro de casa de vegetação (Figura 1).

b.) Sistema convencional: as matrizes foram cultivadas em canteiros de 0,25 cm de altura e 1,0 m de largura levantados dentro de casa de vegetação no 
espaçamento de 1,0 m entre plantas. Os canteiros foram previamente preparados com a mistura de cinco partes de solo para três partes de substrato comercial Geomax, elaborado a partir de casca de pinus e vermiculita. Utilizaram-se duas plantas matrizes por canteiro (Figura 2).

Em ambos os sistemas foram utilizadas irrigação por gotejamento e fertirrigação. Os demais tratos culturais, bem como o manejo fitossanitário das plantas matrizes, foi feito conforme a necessidade da cultura. Com a emissão dos cordões estoloníferos, na condução do sistema "b", os estolhos foram deixados para se desenvolverem sobre os canteiros, permitindo o enraizamento das mudas. No sistema "a”, os estolhos foram mantidos na vertical e suspensos.

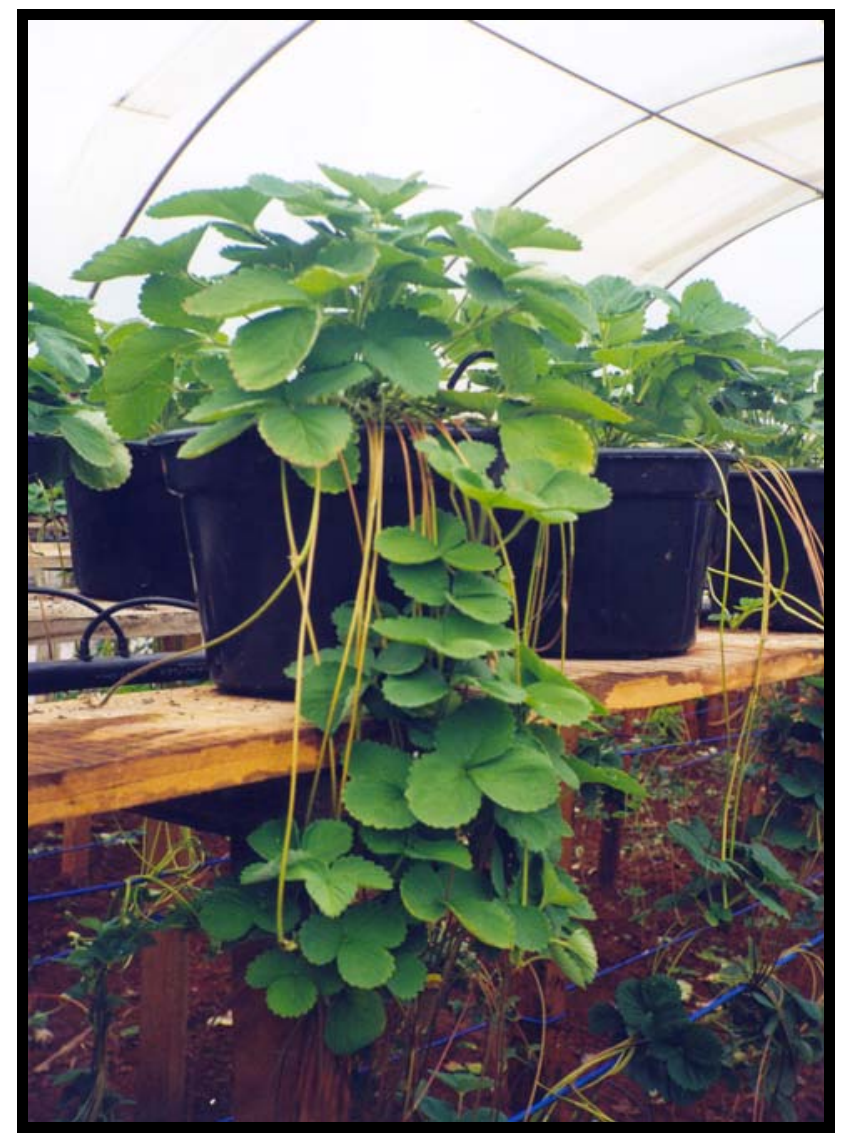

Figura 4 - Matrizes de morangueiro durante a produção de mudas em sistema de vasos suspensos sob cultivo protegido. Piracicaba, 2001 
As mudas de ambos os sistemas foram coletadas e plantadas em bandejas de poliestireno expandido de 128 células preenchidas com vermiculita e levadas para câmara nebulizadora por 15 dias para enraizamento. Após este período foram transplantadas para os canteiros de produção.

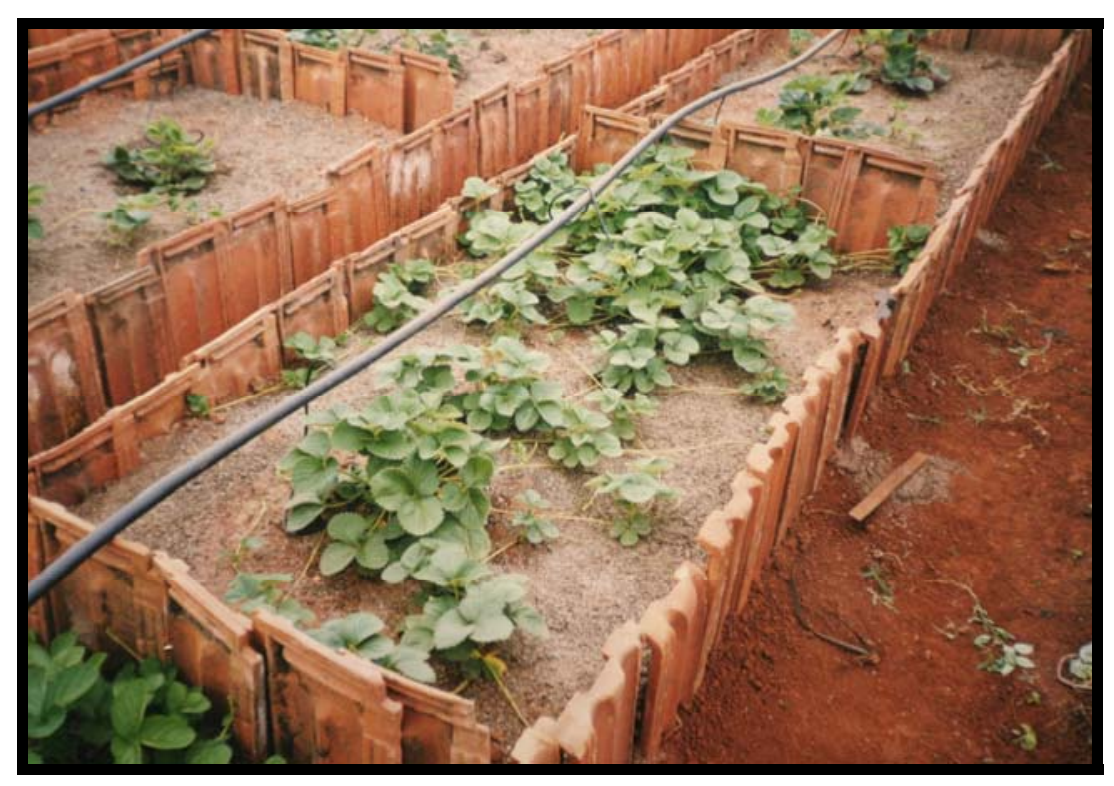

Figura 5 - Matrizes de morangueiro durante a produção de mudas em sistema convencional sob cultivo protegido. Piracicaba, 2001

\subsubsection{Variáveis analisadas}

As variáveis analisadas foram: percentagem de sobrevivência de mudas, matéria seca ( $\mathrm{g} / \mathrm{kg}$ ) e teor de carboidratos totais (mg/100ml de extrato).

Foram realizadas duas análises da percentagem de sobrevivência de mudas. A primeira ocorreu na ocasião do transplante para os canteiros, sendo analisada a sobrevivência das mudas 15 dias após o plantio nas bandejas de poliestireno expandido. A segunda análise foi realizada após 15 dias do transplante para o local definitivo de cultivo, ou seja, 30 dias após o primeiro plantio das mudas.

Para a avaliação da matéria seca e do teor de carboidratos totais foram retiradas amostras na ocasião da coleta das mudas e estas foram encaminhadas para o laboratório de análise do CENA (Centro de Energia Nuclear na Agricultura, Piracicaba, SP). Cada amostra foi constituída por 30 plantas, das quais foram eliminadas as partes 
aéreas, permanecendo para análise apenas os rizomas, no caso das mudas produzidas no sistema "a”, e os rizomas e raízes , no caso das mudas produzidas no sistema "b".

\subsubsection{Delineamento experimental}

Foi utilizado esquema fatorial $3 \times 2$ (três cultivares e dois sistemas de produção de mudas), em blocos ao acaso, com três repetições. Cada repetição foi formada por 30 plantas. Os resultados obtidos foram submetidos à análise de variância através do teste $\mathrm{F}$ e as médias dos tratamentos foram comparadas entre si pelo teste de Tukey ao nível de 5\% de probabilidade.

\subsection{RESULTADOS E DISCUSSÃO}

\subsubsection{Percentagem de sobrevivência de mudas}

Conforme apresentado na Tabela 3, a percentagem de sobrevivência de mudas produzidas no sistema de vasos suspensos aos 15 dias após o plantio foi de $100 \%$ para todas as cultivares. Já para as mudas produzidas pelo sistema convencional foram observadas 93,30\%, 80,00\% e 86,60\% de sobrevivência aos 15 dias para as cultivares IAC-Campinas, IAC-Guarani e Pelican, respectivamente. Entretanto, a cultivar IACCampinas não apresentou diferença estatística entre os dois sistemas de cultivo, fato que ocorreu com as outras duas cultivares.

Análises realizadas pelo Departamento de Entomologia, Fitopatologia e Zoologia da ESALQ demonstraram que a causa da morte de mudas produzidas no sistema convencional foi a infecção pelo fungo Colletotrichum fragariae, comumente conhecida como "chocolate".

De acordo com Tanaka et al (2000), o fungo, normalmente presente no solo, pode infectar as mudas ainda no viveiro, sendo posteriormente transportados para o campo. Embora o inóculo inicial possa ter origem em restos culturais que permanecem no solo e em hospedeiros intermediários, as mudas doentes constituem a principal via de introdução do patógeno na área de produção. 
Tabela 3. Percentagem de sobrevivência de mudas aos 15 e 30 dias após o plantio, para as cultivares de morangueiro IAC-Campinas, IAC-Guarani e Pelican produzidas nos sistemas de vasos suspensos e convencional. Piracicaba, 2002

\begin{tabular}{|c|c|c|c|c|}
\hline \multirow{3}{*}{$\begin{array}{l}\text { Sistema de } \\
\text { Condução } \\
15 \text { dias }\end{array}$} & \multicolumn{3}{|c|}{ Cultivar } & \multirow[b]{2}{*}{$\mathrm{CV} \%$} \\
\hline & IAC-Campinas & IAC-Guarani & Pelican & \\
\hline & \multicolumn{3}{|c|}{ 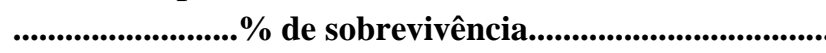 } & \\
\hline vaso & $100.00 \mathrm{aA}$ & $100.00 \mathrm{aA}$ & $100.00 \mathrm{aA}$ & \\
\hline solo & $93.30 \mathrm{aA}$ & $80.00 \mathrm{bB}$ & $86.60 \mathrm{bAB}$ & 5.0 \\
\hline \multicolumn{5}{|l|}{30 dias } \\
\hline vaso & 98.90 aA & $96.60 \mathrm{aA}$ & $97.70 \mathrm{aA}$ & \\
\hline solo & $88.90 \mathrm{bA}$ & $64.40 \mathrm{bC}$ & $77.40 \mathrm{bB}$ & 3.5 \\
\hline
\end{tabular}

Para cada período avaliado, as médias seguidas de mesma letra minúsculas na coluna e maiúscula na linha não diferem entre si pelo teste de Tukey a 5\%.

A produção de mudas no sistema de vasos suspensos impossibilitou a contaminação pelo patógeno, já que estas não estiveram em contato com o solo e as matrizes foram cultivadas e substrato esterilizado. Estes resultados conferem com as observações de Sugiura (1995). Este autor recomenda o uso de bancadas altas para multiplicação de plantas sadias de morangueiro, como forma de evitar a infecção por doenças de solo. Lieten (2002) cita como vantagens do cultivo de mudas em vasos: o menor risco de infecção por doenças de raízes, melhor controle da nutrição das plantas, facilidade de transplante das mudas, sem causar injúrias nas raízes.

Já as mudas produzidas no sistema convencional ficaram mais susceptíveis à contaminação pelo fungo devido ao modo que se processou o arranquio das mesmas dos canteiros de cultivo, que acabou danificando o sistema radicular, favorecendo a penetração do fungo. De acordo com Scarpare Filho (1995), ferimentos causados no sistema radicular por ocasião do transplante de mudas podem servir como porta de entrada para diversos patógenos.

As mudas produzidas no sistema de vasos suspensos apresentaram maior uniformidade, não se diferenciando estatisticamente umas das outras. Já para as mudas produzidas no sistema convencional, a cultivar IAC-Campinas apresentou o maior valor $(93,30 \%)$, sendo este significativamente superior ao da cultivar IAC-Guarani $(80,00 \%)$. 
A cultivar Pelican não apresentou diferença estatística para nenhuma das outras duas, ficando com um valor intermediário (86,60\%). Possivelmente este fato se deve às diferenças genéticas quanto à susceptibilidade de cada cultivar ao fungo Colletotrichum fragariae, já que este foi o agente causador da diminuição da percentagem de sobrevivência.

A percentagem de sobrevivência de mudas 30 dias após o plantio produzidas no sistema de vasos suspensos, foi de 98,90\%, 96,60\% e 97,70\% para as cultivares IAC-Campinas, IAC-Guarani e Pelican, respectivamente; se mostrando estatisticamente superiores às percentagens observadas para as mudas produzidas no sistema convencional, 88,90\%, 64,40\% e 77,40\% (Tabela 3).

Embora a percentagem de sobrevivência das mudas produzidas no sistema de vasos suspensos aos 30 dias tenha decaído em relação à análise aos 15 dias, as mudas produzidas neste sistema ainda assim apresentaram maiores valores quando comparadas com aquelas produzidas no sistema convencional. Assim, nota-se que transplante das mudas para o campo de produção propiciou também a contaminação das mudas produzidas no sistema de vasos suspensos.

Aos 30 dias após o plantio no campo, as mudas produzidas no sistema de vasos suspensos não apresentaram diferenças entre as cultivares quando comparou-se cada sistema individualmente. Já para as mudas produzidas no sistema convencional, as diferenças observadas entre elas se evidenciaram ainda mais. A cultivar IAC-Campinas apresentou o maior valor (88,90\%), sendo seguida pela cultivar Pelican $(77,40 \%)$ e posteriormente pela cultivar IAC-Guarani (64,40\%). Os resultados sugerem que a maior susceptibilidade da cultivar IAC-Guarani ao fungo Colletotrichum fragariae, agente causal da morte das mudas. Já as cultivares IAC-Campinas e Pelican demonstraram maior resistência à esta doença.

Esses resultados concordam com aqueles obtidos por Tanaka et al (1995), que trabalhando com inoculação controlada em coleção de 63 acessos de morangueiro, em Campinas, SP, classificaram a cultivar IAC-Guarani como susceptível e a IACCampinas como de reação intermediária. 
O sistema de produção de mudas em vasos suspensos propiciou a formação de mudas com melhor qualidade fitossanitária devido ao cultivo das matrizes ter sido realizado em substrato esterilizado e à ausência de contato das mudas com o solo. Além disso, a coleta das mudas sem danos ao sistema radicular diminuiu a possibilidade de contaminação por patógenos que normalmente existem no solo.

\subsubsection{Matéria seca}

No que se refere à matéria seca, pode-se observar que não houve diferenças significativas entre as cultivares estudadas em relação ao sistema de produção de muda adotado (Tabela 4). As três cultivares apresentaram valores muito semelhantes tanto quando se comparou o sistema de produção adotado, quanto quando se comparou as cultivares entre si dentro de um mesmo sistema de produção.

Tabela 4. Matéria seca (g/kg) para as cultivares de morangueiro IAC-Campinas, IAC-Guarani e Pelican produzidas nos sistemas de vasos suspensos e convencional. Piracicaba, 2002

\begin{tabular}{|c|c|c|c|c|}
\hline Sistema de & & Cultivar & & \\
\hline Condução & IAC-Campinas & IAC-Guarani & Pelican & CV\% \\
\hline $\mathrm{vaso}$ & $920.81 \mathrm{aA}$ & .matéria seca ... & 92241 aA & \\
\hline solo & $922.31 \mathrm{aA}$ & $928.09 \mathrm{aA}$ & $923.32 \mathrm{aA}$ & 0.25 \\
\hline
\end{tabular}

Para cada período avaliado, as médias seguidas de mesma letra minúsculas na coluna e maiúscula na linha não diferem entre si pelo teste de Tukey a 5\%.

O desenvolvimento do sistema radicular nas mudas produzidas no sistema convencional não ocasionou aumento na matéria seca $(\mathrm{g} / \mathrm{kg})$ em relação às mudas produzidas no sistema de vasos suspensos. Percebe-se que a poda aérea ocasionada pela condução das mudas em vasos suspensos propicia o acúmulo da matéria seca que seria destinada para o desenvolvimento das raízes no rizoma das mudas.

Considerando que no sistema convencional grande parte do sistema radicular é danificado no arranquio das mudas, pode-se concluir que o sistema de vasos suspensos tem como vantagem não desperdiçar matéria seca produzida, já que esta encontra-se acumulada no rizoma das mudas. 


\subsubsection{Teor de carboidratos totais}

A utilização do sistema de vasos suspensos propiciou a formação de mudas com maiores teores de carboidratos totais quando comparadas com as mudas produzidas no sistema convencional para as três cultivares estudadas (Tabela 5). Os resultados foram estatisticamente superiores aos teores observados nas mudas produzidas no sistema convencional. Estes resultados estão de acordo com as observações de Tessarioli Neto (2001).

De acordo com o autor esse fato pode ser atribuído à supressão no desenvolvimento das raízes das mudas no sistema de vasos suspensos, sendo que os elementos fotossintetizados que seriam utilizados no desenvolvimento das raízes ficam acumulados em forma de carboidratos nos rizomas. Já as mudas produzidas no sistema convencional utilizaram estas reservas de carboidratos para o desenvolvimento do sistema radicular.

Tabela 5. Teor de carboidratos totais (mg/100ml de extrato) para as cultivares de morangueiro IAC-Campinas, IAC-Guarani e Pelican produzidas nos sistemas de vasos suspensos e convencional. Piracicaba, 2002

\begin{tabular}{|c|c|c|c|c|}
\hline \multirow{2}{*}{$\begin{array}{l}\text { Sistema de } \\
\text { Condução }\end{array}$} & \multicolumn{3}{|c|}{ Cultivar } & \multirow[b]{2}{*}{$\mathrm{CV} \%$} \\
\hline & IAC-Campinas & IAC-Guarani & Pelican & \\
\hline & \multicolumn{3}{|c|}{ 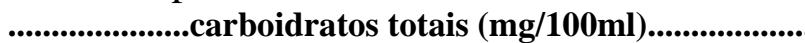 } & \\
\hline vaso & $247.08 \mathrm{aA}$ & $243.94 \mathrm{aA}$ & $260.32 \mathrm{aA}$ & \\
\hline solo & $114.69 \mathrm{bB}$ & $159.73 \mathrm{bA}$ & $72.66 \mathrm{bC}$ & 10.7 \\
\hline
\end{tabular}

Para cada período avaliado, as médias seguidas de mesma letra minúsculas na coluna e maiúscula na linha não diferem entre si pelo teste de Tukey a 5\%.

Assim, ausência de contato com o solo nas mudas produzidas em sistema de vasos suspensos favoreceu a qualidade fisiológica das mudas devido ao maior acúmulo de carboidratos totais nos rizomas, o que conferiu um maior vigor inicial às mudas.

No sistema convencional as reservas utilizadas na formação das raízes foram praticamente desperdiçadas, uma vez que as mudas produzidas diretamente no 
solo foram transplantadas na forma de raíz nua, fato que acabou danificando grande parte do sistema radicular, ocasionando grande estresse na fase de desenvolvimento inicial das mesmas no campo e favorecendo o desenvolvimento da antracnose.

\subsection{CONCLUSÕES}

O sistema de produção de mudas em vasos suspensos propicia a formação de mudas com maiores teores de carboidratos totais nos rizomas do que mudas produzidas diretamente no solo.

As mudas produzidas em sistema de vasos suspensos dentro de casa de vegetação apresentaram vantagens quando comparadas com mudas produzidas no sistema convencional no que se diz respeito à qualidade fitossanitária e fisiológica. 


\section{FRIGOCONSERVAÇÃO DE MUDAS DE MORANGUEIRO PRODUZIDAS EM SISTEMA DE VASOS SUSPENSOS}

\section{Resumo}

Com o objetivo de estudar a frigoconservação em mudas de morangueiro (Fragaria x ananassa Duch.) produzidas em sistema de vasos suspensos, foram realizados dois experimentos nos períodos de 2000-2001 e 2002-2003. Após a coleta, as mudas foram acondicionadas em sacos de polietileno e frigoconservadas durante 120 dias em uma B.O.D. à $-1 \pm 1^{\circ} \mathrm{C}$. Foram então retiradas da câmara fria e plantadas em bandejas de poliestireno expandido de 128 células preenchidas com vermiculita. As bandejas foram colocadas em uma câmara nebulizadora onde permaneceram por 21 dias para enraizamento. Em seguida foram transplantadas para vasos de $250 \mathrm{ml}$ e levadas para casa de vegetação. Foi avaliada a percentagem de sobrevivência das mudas. No primeiro ensaio utilizou-se cinco cultivares (IAC-Campinas, Dover, Pelican, Sequoia e Sweet Charlie) no delineamento experimental inteiramente ao acaso com nove repetições. No segundo ensaio foi utilizado o esquema fatorial 5x2 (cinco cultivares: IAC-Campinas, Oso Grande, Camarosa, Dover e Sweet Charlie; e dois tratamentos de enraizamnto: com e sem ácido indol butírico), em blocos ao acaso, com quatro repetições. Os resultados obtidos foram submetidos a análise de variância através do teste $\mathrm{F}$ e as médias dos tratamentos foram comparadas entre si pelo teste de Tukey, ao nível de 5\% de probabilidade. A frigoconservação de mudas de morangueiro produzidas em sistema de vasos suspensos apresentou baixa percentagem de sobrevivência de mudas nos dois experimentos. Assim, o sistema de frigoconservação adotado não se mostrou viável.

Palavras-chave: Fragaria x ananassa Duch., produção de mudas, ácido indol butírico 


\section{Storage cold of strawberry runners produced in system of suspended pots}

\section{Summary}

With the objective of studying the storage cold in strawberry runners (Fragaria $x$ ananassa Duch.) produced in system of suspended pots, two experiments were done in the periods of 2000-2001 and 2002-2003. In both experiments the runners were produced in the system of suspended pots. After the selection, the runners were conditioned in polyethylene bags and storage cold conditions for 120 days in a B.O.D. After that they were removed of the cold camera and planted in trays of expanded polystyrene of 128 cells with vermiculite. The trays were put in a spray chamber 21 days for rooting. After that hey were transplanted to pots of $250 \mathrm{~mL}$ and then placed in the greenhouse. It was evaluated the percentage of runners survival. In the first experiment it was used the experimental entirely random design, five strawberry cultivars (IACCampinas, Dover, Pelican, Sequoia and Sweet Charlie), and nine repetitions. In the second experiment the factorial outline used was 5x2 (five cultivars: Campinas, Oso Grande, Camerosa, Dover and Swit Charlie; and two treatments: with and without indol butyric acid) with four repetitions. The results were submitted to analysis of variance through the $\mathrm{F}$ test, and this being significant, the averages of the treatments were compared amongst themselves by the test of Tukey at the level of $5 \%$ of probability. The storage cold of strawberry runners produced in system of suspended pots lower percentage of survival of seedlings in the two experiments. Therefore, the system of storage cold was not viable.

Keywords: Fragaria x ananassa Duch., runners production, acid indol butyric 


\subsection{INTRODUÇÃO}

A variação sazonal dos preços na cultura do morangueiro é bastante acentuada e os melhores preços são obtidos nos meses de abril a junho, quando a oferta do produto é muito pequena, em razão das condições climáticas das regiões produtoras e das características das cultivares exploradas. Este fato justifica a crescente busca, por parte dos pesquisadores, de técnicas que proporcionem aos produtores de morango produções mais precoces (Camargo Filho, 1994; Duarte Filho et al., 1999).

De acordo com Lieten (2002) a frigoconservação de mudas de morangueiro possibilita que muitos produtores europeus prolonguem o período produtivo, obtendo uma produção satisfatória depois do pico de produção, quando os preços pagos aos produtores são mais elevados.

Duarte Filho et al. (1999) citam como vantagens do uso desse tipo de muda a possibilidade de aumentar o período de oferta de mudas aptas ao plantio, no momento mais oportuno, conforme o clima e cultivares. Essa técnica permite ainda, quando necessário, satisfazer as exigências de horas de frio destas mudas.

Nos países onde é comum a frigoconservação de mudas, essas são produzidas diretamente no solo em canteiros. As mudas são arrancadas do viveiro quando se encontram no estádio de latência. Nessa condição o seu conteúdo de substâncias de reservas é adequado, o que favorece sua conservação (Branzanti, 1989).

As condições físicas das plantas no arranquio são determinantes para o sucesso de uma longa conservação. As plantas devem ser expostas a um mínimo de horas de frio de acordo com as características de cada cultivar e terem um certo nível de dormência antes de serem armazenadas por longos períodos. Estudos demonstraram que somente plantas que acumularam reservas suficientes podem ser armazenadas (Lieten, 1996). O mesmo autor cita que os melhores armazenamentos e posteriores produções são obtidos com mudas que permanecem encanteiradas recebendo entre 500 a 800 horas de temperaturas inferiores a $7^{\circ} \mathrm{C}$ e apresentam teores entre 100 a $140 \mathrm{mg}$ de açucares totais por grama de matéria seca. Por ocasião do arranquio das mudas, clima seco e temperaturas baixas $\left(1 \mathrm{a} 7^{\circ} \mathrm{C}\right)$ favorecem o processo de armazenagem. 
Após o arranquio, é feita uma limpeza, eliminando-se os resíduos de solo aderidos às raízes. A seguir, cortam-se as folhas, cuja presença dificulta a conservação das mudas além de aumentar o volume por elas ocupado. Já o sistema radicular deve ser mantido intacto o máximo possível, para aproveitar melhor as substâncias de reserva que ele contém (Branzanti, 1989).

Recomenda-se que as mudas sejam empacotadas de acordo com as dimensões do rizoma. Alguns pesquisadores recomendam a utilização de sacos plásticos com espessura de 0,07 mm, entretanto não existem diferenças quanto à armazenagem, vigor e produção de frutos para plantas armazenadas em sacos plásticos com espessura entre 0,02 e 0,07 mm (Linden, 1964).

Para longos períodos de armazenamento a temperatura deve ser mantida na faixa de -1 a $-2^{\circ} \mathrm{C}$, a qual bloqueia as atividades vegetativas e não causa danos aos tecidos das plantas (Branzanti, 1989). Temperaturas inferiores a $-3^{\circ} \mathrm{C}$ podem causar injurias nos tecidos dos rizomas, reduzindo o vigor e a produção (Lieten \&Goffings, 1996).

De acordo com Tessarioli Neto (2001), as mudas de morangueiro produzidas em sistema de vasos suspensos apresentam maiores teores de carboidratos em seus rizomas quando comparadas com mudas produzidas diretamente no solo. O autor explica que uma das possíveis explicações para este comportamento está no fato das mudas produzidas em vasos suspensos não desenvolverem raízes, e desta forma concentrarem os fotossintetizados. Estas mudas apresentam ainda melhores qualidades fitossanitárias quando comparadas com mudas produzidas convencionalmente no solo.

O objetivo destes experimentos foi avaliar a viabilidade da utilização do sistema de frigoconservação em mudas de morangueiro produzidas no sistema de vasos suspensos, já que estas apresentam maiores teores de carboidratos totais, essenciais para uma perfeita armazenagem à baixas temperaturas. 


\subsection{MATERIAL E MÉTODOS}

Foram realizados dois experimentos nos períodos de 2000-2001 e 20022003 no Departamento de Produção Vegetal - ESALQ/USP, Piracicaba/SP, com a finalidade de estudar a frigoconservação de mudas de morangueiro produzidas em sistema de vasos suspensos.

\subsubsection{Experimento 2000-2001}

\section{a. Cultivares e produção de mudas}

Foram utilizadas as cultivares IAC-Campinas, Dover, Pelican, Sequóia e Sweet Charlie. As plantas matrizes foram adquiridas da empresa Multiplanta e plantadas no dia 11 de novembro de 2000 em vasos de 5 L preenchidos com o substrato comercial GEOMAX II formulado a partir de casca de pinus e vermiculita.

Os vasos foram conduzidos sobre uma bancada a $1,5 \mathrm{~m}$ do solo. Foi utilizada irrigação por gotejamento e fertirrigação com os seguintes adubos: MAP, Nitrato de Potássio, Nitrato de Cálcio e Nitrato de Magnésio. Além disso, foram feitas pulverizações para suplementação de micronutrientes com o adubo “Tenso Cocktail”. O tratamento fitossanitário foi feito conforme a necessidade.

\section{b. Coleta e classificação das mudas}

A coleta das mudas foi realizada no dia 26 de abril de 2001. Estas foram classificadas em Extra, Tipo 1, Tipo 2 e Descarte, de acordo com os parâmetros estabelecidos por Ortigoza (1999). Para a experimentação foram utilizadas apenas as mudas pertencentes às categorias Tipo 1 , por representarem a média das mudas obtidas.

\section{c. Tratamento das mudas}

Foi realizada a eliminação das folhas das mudas e estas foram postas para curar à sombra, à temperatura ambiente, durante 24 horas. Após esse período foi feito o tratamento preventivo das mudas através da imersão em uma solução de Benomil a 5\%.

Foram então acondicionadas em sacos de polietileno transparentes com espessura de 0,03 mm, em lotes de 15 mudas, e levadas para câmara fria $\left(-1 \pm 1^{\circ} \mathrm{C}\right)$, 
onde permaneceram durante 120 dias. Após o período de frigoconservação, as mudas foram retiradas da câmara fria e deixadas na temperatura ambiente do laboratório $\left(22^{\circ} \mathrm{C}\right.$, aproximadamente), durante 6 horas, dentro das próprias embalagens em que foram armazenadas.

No dia 27 de agosto as mudas foram plantadas em bandejas de isopor de 128 células, preenchidas com vermiculita, e levadas para câmara úmida onde permaneceram durante 21 dias para enraizamento. Após este período, as mudas foram transplantadas para vasos plásticos de $250 \mathrm{~mL}$ preenchidos com o mesmo tipo de substrato comercial utilizado na condução das matrizes. Os vasos foram conduzidos sobre bancada e receberam sistema de irrigação e fertirrigação localizada por gotejamento.

\section{d. Variáveis analisadas}

Foi analisada a percentagem de sobrevivência de mudas. Para isso foram feitas duas avaliações, a primeira aos 21 dias após o plantio nas bandejas de isopor e a segunda aos 30 dias após o transplante para os vasos.

\section{e. Delineamento experimental}

Utilizou-se o delineamento experimental inteiramente casualizado, sendo cinco cultivares (IAC-Campinas, Dover, Pelican, Sequoia e Sweet Charlie), e nove repetições. Cada parcela foi formada por 15 mudas. Os resultados obtidos foram submetidos a análise de variância através do teste $\mathrm{F}$ e as médias dos tratamentos foram comparadas entre si pelo teste de Tukey, ao nível de 5\% de probabilidade. 


\subsubsection{Experimento 2002-2003}

\section{a. Cultivares e produção de mudas}

As cultivares utilizadas no ensaio 2002-2003 foram IAC-Campinas, Oso Grande, Camarosa, Dover e Sweet Charlie. As matrizes foram plantadas no dia 30 de outubro de 2002. O cultivo das plantas matrizes e produção de mudas foram idênticas ao ensaio 2000-2001. A coleta das mudas ocorreu no dia 10 de março de 2002 e o transplante para as bandejas de isopor após a frigoconservação foi feito em 10 de junho de 2003.

\section{b. Tratamento das mudas}

Em relação ao experimento anterior foi incluído um tratamento com o hormônio vegetal ácido indol butírico (IBA) a fim de estimular o enraizamento das mudas. Este tratamento consistiu na imersão da base das mudas em uma solução de IBA (200ppm). As mudas foram levadas para enraizamento em câmara nebulizadora por 21 dias. Após este período as mudas sobreviventes foram transplantadas para vasos plásticos de 250mL preenchidos com uma mistura de areia tratada com hipoclorito de sódio a 5\% e vermiculita na proporção de 4:1 (V:V), respectivamente.

\section{c. Variáveis analisadas}

Foi analisada a percentagem de sobrevivência de mudas. Para isso foram feitas duas avaliações, a primeira aos 21 dias após o plantio nas bandejas de isopor e a segunda aos 30 dias após o transplante para os vasos.

\section{d. Delineamento experimental}

Utilizou-se o delineamento experimental no esquema fatorial $5 x 2$, sendo cinco cultivares (IAC-Campinas, Oso Grande, Camarosa, Dover e Sweet Charlie) e dois tratamentos com reguladores de crescimento (com IBA e e sem IBA), em blocos ao acaso, com quatro repetições. Cada parcela foi formada por 30 mudas. Os resultados obtidos foram submetidos a análise de variância através do teste $\mathrm{F}$ e as médias dos 
tratamentos foram comparadas entre si pelo teste de Tukey ao nível de $5 \%$ de probabilidade.

\subsection{RESULTADOS E DISCUSSÃO}

\subsubsection{Experimento 2000-2001}

Os resultados referentes a percentagem de sobrevivência das mudas após a frigoconservação no período de 2000 a 2001 encontram-se na Tabela 6.

Tabela 6. Percentagem de sobrevivência de mudas de morangueiro frigoconservadas após 21 dias de plantio (\% 21 - bandeja) e após 30 dias do transplante para os vasos (\% 30 - vaso) Piracicaba, 2001

\begin{tabular}{lcc}
\hline CULTIVARES & \% 21 - bandeja & \% $\mathbf{3 0}$ - vaso \\
IAC-Campinas & $47.11 \mathrm{a}$ & $33.0 \mathrm{bc}$ \\
Dover & $49.22 \mathrm{a}$ & $40.44 \mathrm{ab}$ \\
Sweet Charlie & $54.44 \mathrm{a}$ & $47.66 \mathrm{a}$ \\
Sequoia & $30.77 \mathrm{~b}$ & $14.55 \mathrm{~d}$ \\
Pelican & $45.55 \mathrm{a}$ & $26.33 \mathrm{c}$ \\
\hline CV\% & 23.13 & 26.94 \\
\hline
\end{tabular}

Médias seguidas de mesma letra minúscula na coluna não diferem entre si pelo teste de Tukey a 5\%.

Conforme observado na Tabela 6, após o período de frigoconservação, houve uma grande mortalidade de mudas. Com exceção da cultivar Sweet Charlie, todas as outras cultivares tiveram menos que 50\% de mudas sobreviventes, sendo que a cultivar Sequoia diferenciou-se estatisticamente das demais por apresentar apenas 30,77\% de percentagem de sobrevivência após a frigoconservação. Biggy (2000) cita que o sucesso da frigoconservação pode variar conforme a cultivar utilizada.

Observa-se ainda que após 30 dias, a sobrevivência das mudas teve mais decréscimo, sendo que, mesmo aquelas mudas que já haviam iniciado o desenvolvimento acabaram morrendo.

Nos países onde é comum a frigoconservação de mudas, essas são produzidas diretamente no solo em canteiros. As mudas são arrancadas do viveiro quando se encontram no estádio de latência. Nessa condição o seu conteúdo de substâncias de reservas é adequado, o que favorece sua conservação (Branzanti, 1989). 
No cultivo tropical do morangueiro não ocorrem condições climáticas que possibilitem que as mudas passem pelo número de horas de frio necessário e entrem em latência acumulando as reservas. As mudas apresentam-se constantemente vegetativas, e tal condição desfavorece a frigoconservação das mesmas.

Embora as mudas produzidas no sistema de vasos suspensos apresentem maiores teores de carboidratos quando comparadas com mudas produzidas convencionalmente (Tessarioli Neto, 2001), isto não foi suficiente para sucesso da frigoconservação.

Este fato concorda com Lieten (1996). De acordo com este autor as condições físicas das plantas no arranquio são determinantes para o sucesso de uma longa conservação. As plantas devem ser expostas a um mínimo de horas de frio de acordo com as características de cada cultivar e terem um certo nível de dormência antes de serem armazenadas por longos períodos. Pouco antes da planta entrar em dormência, ocorre uma paralisação no crescimento e uma produção excessiva de carboidratos, os quais são estocados em vários órgãos (coroa, pecíolos e raízes primárias), principalmente na forma de amido. Esse amido é hidrolisado durante os períodos mais frios, visto que os carboidratos formados baixam o ponto de congelamento do suco celular, fazendo com que a planta resista às temperaturas reduzidas.

Pode-se concluir que embora aos teores de carboidratos totais sejam maiores nas mudas produzidas no sistema suspenso, é essencial que, além disso, estas estejam num estagio de dormência na ocasião da frigoconservação, fato este que nõ ocorre naturalmente nas condições tropicais de cultivo. 


\subsubsection{Experimento 2002-2003}

Os resultados referentes a percentagem de sobrevivência das mudas após a frigoconservação no período de 2002 a 2003 encontram-se na Tabela 7.

Tabela 7. Percentagem de sobrevivência de mudas de morangueiro frigoconservadas após 21 dias de plantio (\% 21 - bandeja) e após 30 dias do transplante para os vasos (\% 30 - vaso), em função da aplicação ou não de IBA, Piracicaba, 2003

\begin{tabular}{lllll} 
& \multicolumn{2}{c}{$\% \mathbf{2 1}$ - bandeja } & \multicolumn{2}{c}{$\% \mathbf{3 0}$ - vaso } \\
CULTIVARES & S/IBA & C/IBA & S/IBA & C/IBA \\
IAC-Campinas & 30.00 ab A & 36.36 ab A & 20.00 a A & 22.21 a A \\
Dover & 33.33 a A & 25.54 b A & 26.77 a A & 20.00 a A \\
Sweet Charlie & 36.65 a A & 44.43 a A & 24.42 a A & 26.65 a A \\
Oso Grande & 27.77 b A & 32.22 ab A & 21.11 a A & 24.31 a A \\
Camarosa & 31.11 a A & 31.1. ab A & 24.43 a A & 21.11 a A \\
\hline CV\% & 17.86 & & 20.92 & \\
\hline
\end{tabular}

Para cada período avaliado, as médias seguidas de mesma letra minúsculas na coluna e maiúscula na linha não diferem entre si pelo teste de Tukey a 5\%.

Analisando o segundo ensaio (Tabela 7), observa-se que mesmos nos tratamentos onde se utilizou o hormônio IBA para favorecer o enraizamento das mudas frigoconservadas, este não influenciou o aumento na taxa de sobrevivência das mesmas.

O uso de hormônio de enraizamento não mostrou-se eficaz devido ao fato das mudas não resistirem ao período de armazenamento, encontrando-se prejudicadas já no plantio. Isto demonstra mais uma vez que as condições da muda na ocasião da frigoconservação são essenciais para o sucesso da técnica.

\subsection{CONCLUSÕES}

A frigoconservação das mudas de morangueiro produzidas no sistema de vasos suspensos nas condições climáticas de Piracicaba acarretou uma baixa percentagem de sobrevivência das plantas após o plantio, mostrado-se inviável dentro da metodologia utilizada. 


\section{EFEITO DA VERNALIZAÇÃO EM CINCO CULTIVARES DE MORANGUEIRO EM DUAS LOCALIDADES}

\section{Resumo}

Visando a obtenção de frutos na entressafra, este experimento teve como objetivo estudar o efeito da vernalização em mudas de cinco cultivares de morangueiro. As mudas foram produzidas no sistema de vasos suspensos. Para que houvesse disponibilidade de mudas na época de entressafra, estas foram plantadas em vasos de $250 \mathrm{ml}$ preenchidos com substrato formulado com areia e vermiculita (4:1) e mantidas em casa de vegetação durante seis meses. $\mathrm{O}$ delineamento experimental utilizado foi o fatorial 5x2, com cinco cultivares (IAC-Campinas, Dover, Sweet Charlie, Cartuno e Oso Grande) e dois tratamentos (com e sem vernalização das mudas) em blocos ao acaso, com quatro repetições. Para vernalização, as mudas foram levadas para câmara fria à temperatura de $10 \pm 2^{\circ} \mathrm{C}$, e fotoperíodo de $10 \mathrm{~h}$ de luz/dia durante 28 dias. Em seguida, foram transplantadas para dois locais de cultivo com características climáticas distintas, Piracicaba,SP e Caldas,MG. Foram avaliadas as percentagens de sobrevivência, florescimento, frutificação e emissão de estolhos e o peso e número de frutos produzidos por planta. A sobrevivência de mudas não foi afetada pela vernalização em nenhuma das localidades. Houve efeito significativo no florescimento e na frutificação das plantas vernalizadas apenas em Piracicaba. O estolonamento de plantas foi mais precoce em Piracicaba. Para todas as cultivares a produção de frutos foi e insignificante e comercialmente inviável em ambas localidades.

Palavras chave: Fragaria x ananassa Duch.; produção precoce, produção de mudas, condicionamento de mudas. 


\section{Effect of vernalization on five cultivars of strawberry in two sites}

\section{Summary}

The strawberry production (Fragaria x ananassa Duch.) is very seasonal, and the best fruit prices are obtained during the off season. Seeking to get fruits off season the experiment had the objective of studying the effect of the runner vernalization of five strawberry cultivars. The strawberry runners were produced in suspended pot system. In order to have availability of strawberry runners during the off season, they were planted in pots of $250 \mathrm{~mL}$, filled out with substrate formulated with sand and vermiculite (4:1) and kept in the greenhouse for six months. Completely randomized blocks with the factorial design $5 \times 2$, with five strawberry cultivars (IAC-Campinas, Dover, Sweet Charlie, Cartuno and Oso Grande) and two treatments (with and without strawberry runners vernalization). For vernalization, the strawberry runners were taken from cold camera to the temperature of $10+2{ }^{\circ} \mathrm{C}$, and fotoperiod of $10 \mathrm{~h}$ of light/day for 28 days. After that, they were transplanted for two cultivation places with different climatic conditions, Piracicaba/SP and Caldas/MG. They were analyzed the survival percentages, flower blooming, fructification and emission of stolons and the weight and number of fruits produced by plant. The strawberry runners survival was not affected by the vernalization in none of the places. There were only significant effect on flower appearance and fructification of the vernalized plants, only in Piracicaba. The runner emitions were earlier in Piracicaba. For all strawberry cultivars the production of fruits was very low and the produced fruits were unsuitable for commercialization in both places.

Keywords: Fragaria x ananassa Duch., earlier yield, runners production 


\subsection{INTRODUÇÃO}

A variação sazonal dos preços do morango é bastante acentuada, sendo que os melhores preços são obtidos nos meses de abril a junho, quando a oferta do produto é muito pequena, em razão das condições climáticas das regiões produtoras e das características das cultivares exploradas. Este fato justifica a crescente busca, por parte dos pesquisadores, de técnicas que proporcionem aos produtores de morango produções mais precoces (Duarte Filho et al., 1999).

A maioria das cultivares de morangueiro atualmente utilizadas no Brasil se comportam como plantas de dia curto, isto é, necessitam que haja diminuição do fotoperíodo para iniciarem o florescimento e a frutificação. Em condições de temperaturas elevadas e de dias longos, as plantas emitem estolhos que a cada dois nós (em geral), emitem folhas e enraízam (Ronque, 1998). Segundo o mesmo autor, os fatores climáticos de maior expressão que afetam a cultura são a temperatura e o fotoperiodismo, sendo que a temperatura exerce maior influência. Fatores como estiagem, chuvas excessivas, alta e baixa umidade e a qualidade e intensidade da luz, também exercem influência, mas em menor grau de importância.

Para que ocorra a indução floral, a temperatura e o fotoperíodo devem permanecer favoráveis por um espaço de tempo suficiente, denominado ciclo indutivo. Diversos autores concluíram que o número mínimo de ciclos de dia curto para induzir o florescimento, nas cultivares octaplóides, está normalmente entre 7 a 14 dias, podendo chegar a 23 dias, conforme citações de Guttridge (1985).

Brandão Filho et al. (1989) estudando o efeito da vernalização por 10, 15 e 20 dias a uma de temperatura de $10^{\circ} \mathrm{C}$ na cultivar de morango AGF-80, verificaram que a vernalização teve efeito significativo e que o aumento do tempo de vernalização promoveu a precocidade no aparecimento de botões florais diferenciados, botões visíveis e flores abertas. 
Baldini (1997) estudando a vernalização de mudas de morangueiro das cultivares IAC-Campinas e Tonoyoka submetidas à temperatura entre $8-10^{\circ} \mathrm{C}$ e 8 horas de luz/dia, durante 20 dias, constatou uma sobrevivência de 98,1\% aos 10 dias do transplante para as duas cultivares, e 92,6 e 96,3\% aos 21 dias para as cultivares IAC-Campinas e Toyonoka, respectivamente. A pesquisadora cita ainda, que a vernalização das mudas estimulou a emissão de botões florais, sendo que 62,9 e 61,1\% das plantas das cultivares IAC-Campinas e Toyonoka apresentaram inflorescência aos 40 dias do transplante respectivamente. A vernalização das mudas propiciou a antecipação da colheita, sendo que a produção de frutos (peso e número) foi superior nas quatro primeiras semanas quando comparadA com tratamentos que não sofreram vernalização.

Assim, a vernalização de mudas de morangueiro mostra-se como uma possível alternativa para produção de frutos na entressafra, possibilitando maiores ganhos pelos produtores.

\subsection{MATERIAIS E MÉTODO}

O experimento foi conduzido no Departamento de Produção Vegetal, ESALQ/USP, Piracicaba,SP, no período de outubro de 2001 a março de 2003.

\subsubsection{Cultivares e produção de mudas}

As cultivares utilizadas foram IAC-Campinas, Dover, Oso Grande, Cartuno, e Sweet Charlie. As plantas matrizes foram adquiridas da empresa Multiplanta, Andradas, MG. As mudas foram produzidas no sistema de vasos suspensos (Figura 6).

A coleta das mudas ocorreu no dia 10 de maio de 2002. Estas foram separadas da planta matriz com o auxílio de uma tesoura e colocadas em sacos plásticos de acordo com a cultivar. Após a coleta, foi feita uma padronização de acordo com o tamanho das mesmas em Tipo 1, Tipo 2 e Descarte, de acordo com os parâmetros estabelecidos por Ortigoza (1999). Foram utilizadas as mudas do tipo 2, por representarem a média das mudas produzidas. 
As mudas selecionadas foram plantadas em bandejas de isopor de 128 células, preenchidas com vermiculita, e levadas para enraizamento em câmara úmida por 15 dias. Após este período, as mudas foram transplantadas para vasos plásticos de 250ml preenchidos com uma mistura de areia tratada com hipoclorito de sódio a 5\% e vermiculita na proporção de 4:1 (V:V), respectivamente.

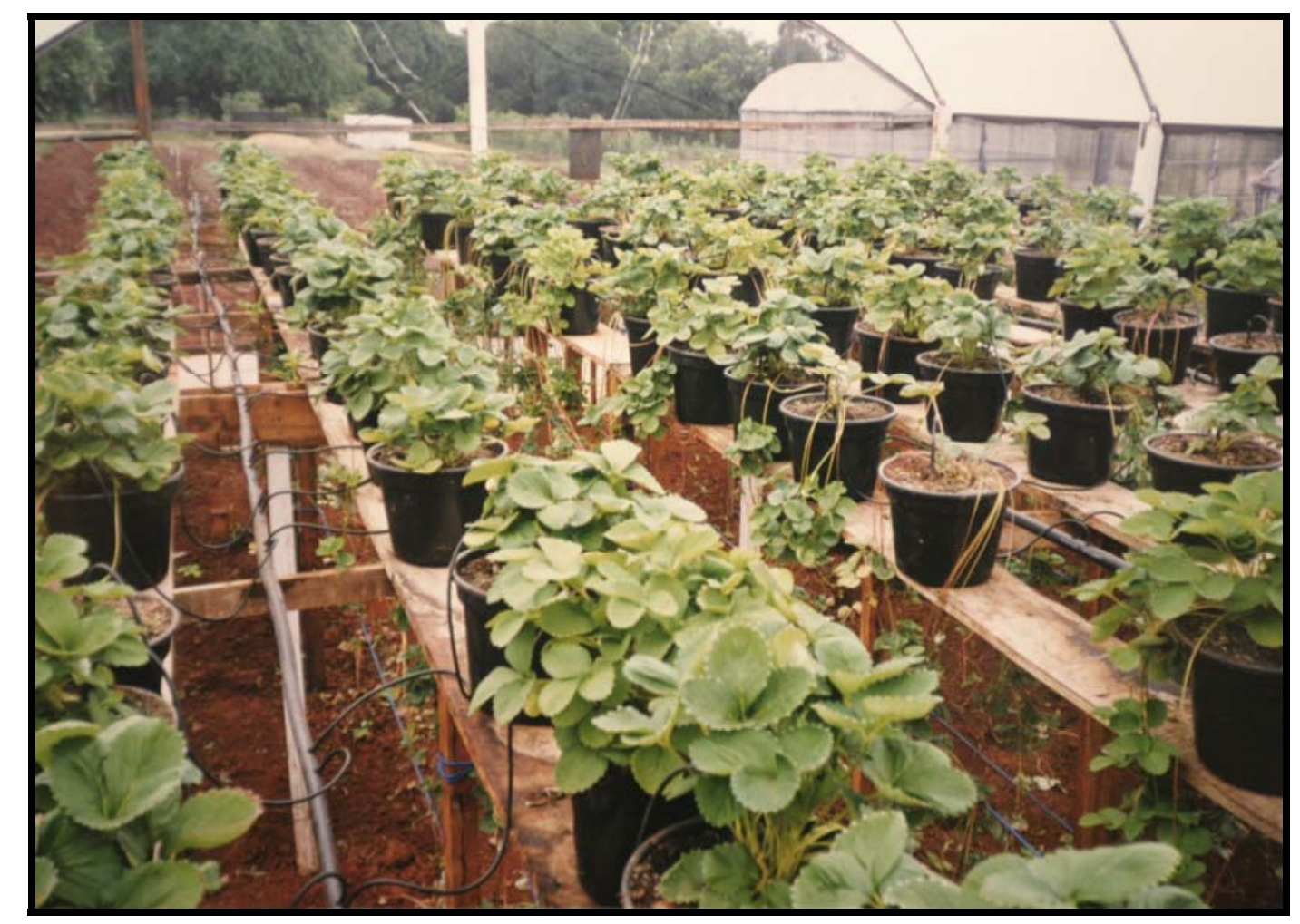

Figura 6 - Sistema de produção de mudas de morangueiro em vasos suspensos. Piracicaba/SP, 2002

Para que as mudas pudessem ser testadas na entressafra, estas foram mantidas em casa de vegetação por seis meses em um período de “espera” (Figura 7). A fim de controlar o desenvolvimento das plantas foi reduzido o fornecimento de nutrientes (20\% do recomendado) e procedeu-se a retirada de flores e estolhos. Durante o período de “espera” foram feitas três pulverizações com o produto Vertimec a fim de controlar a infestação de ácaros. 


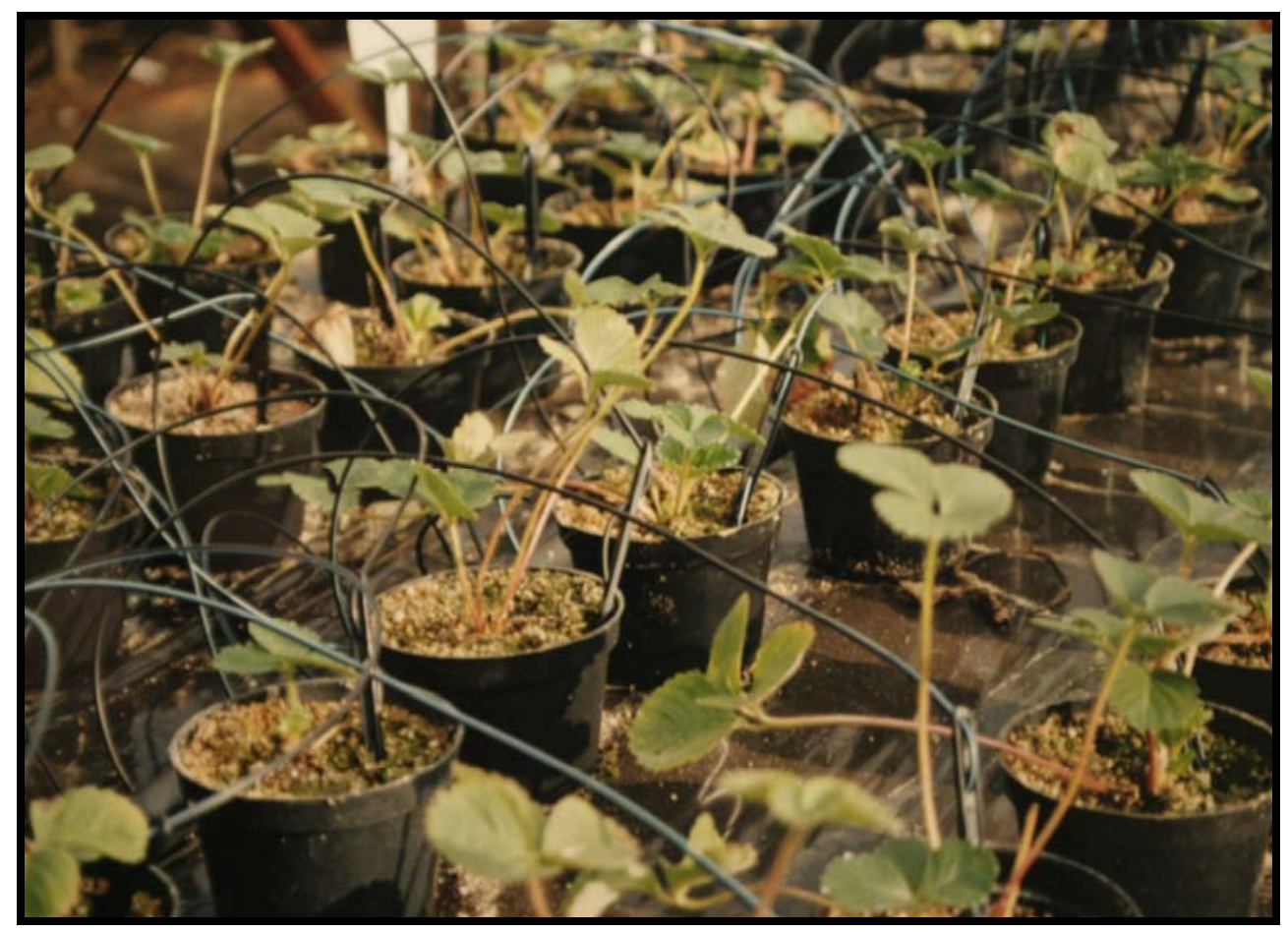

Figura 7 - Mudas de morangueiro em vasos durante o período de “espera”. Piracicaba/SP, 2002

\subsubsection{Tratamentos - Vernalização das mudas}

Foram utilizados dois tratamentos, com e sem vernalização das mudas. As mudas que não sofreram vernalização foram denominadas de Testemunha. Para vernalização, as mudas foram colocadas em uma câmara fria e mantidas a temperatura de $10 \pm 2{ }^{\circ} \mathrm{C}$ e fotoperíodo de 8 horas de luz por dia, onde permaneceram durante 28 dias (Figura 8). Durante este período a irrigação foi manual e não foi feita nenhum tipo de adubação ou tratamento fitossanitário nas mudas. 


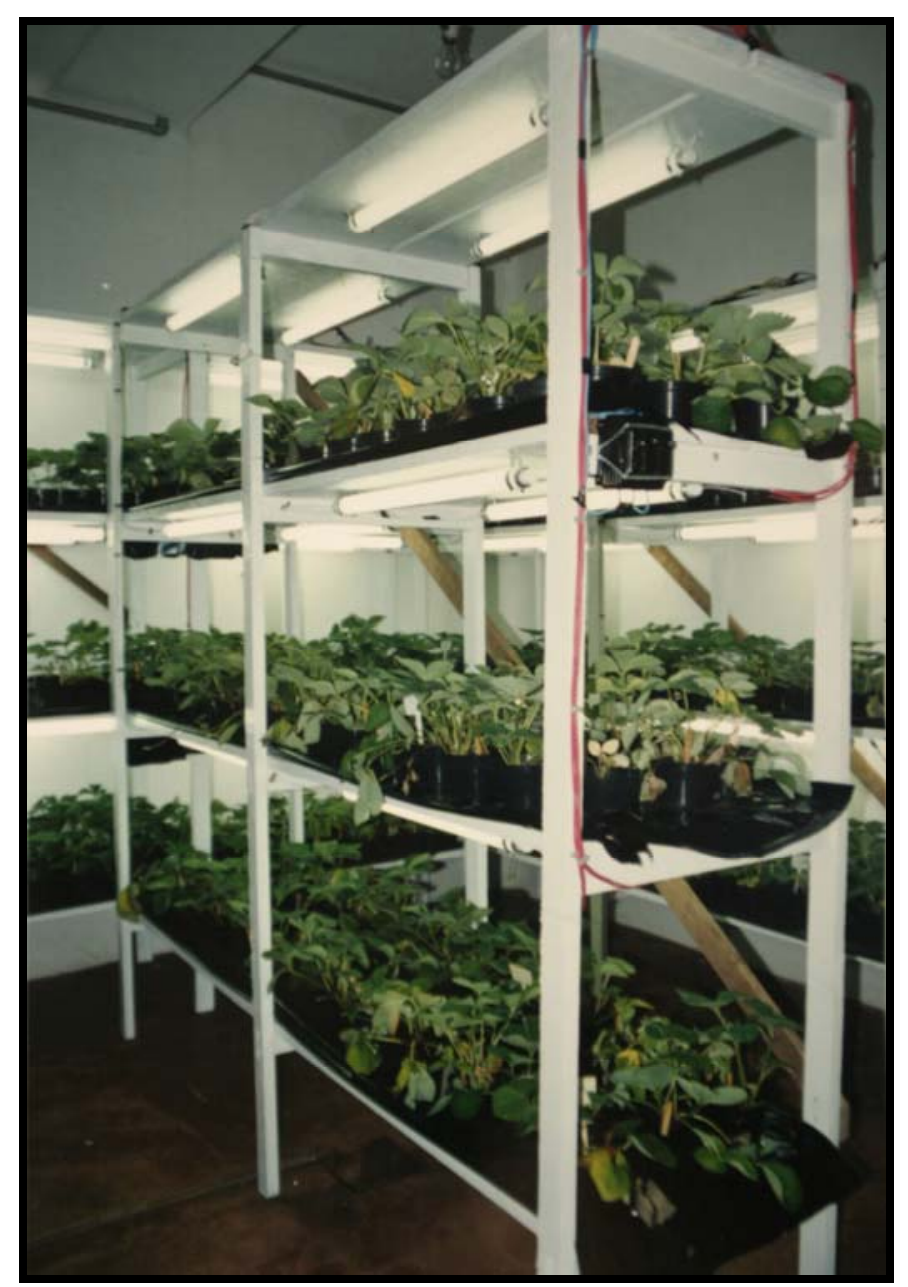

Figura 8 - Sistema de vernalização de mudas de morangueiro em câmara fria. Piracicaba/SP, 2003 


\subsubsection{Plantio e condução das mudas no campo}

Foi feita aração, gradagem e encanteiramento. Para adubação de plantio utilizou-se o formulado 4-14-8 na quantidade recomendada por Passos et al (1998), conforme análise de solo. O sistema de irrigação utilizado foi por gotejamento através de mangueiras estendidas sobre os canteiros.

No dia 02 de dezembro de 2002 as plantas foram retiradas da câmara fria e juntamente com as testemunhas levadas para as áreas de cultivo em Piracicaba,SP e Caldas,MG (Figura 9), onde foram transplantadas imediatamente no espaçamento de $0.3 \mathrm{~m}$ entre plantas. Três dias após o transplante os canteiros foram cobertos com plástico preto e foi instalado um túnel baixo para proteção das plantas contra chuva. Procederam-se normalmente os tratos culturais e o manejo fitossanitário da cultura.

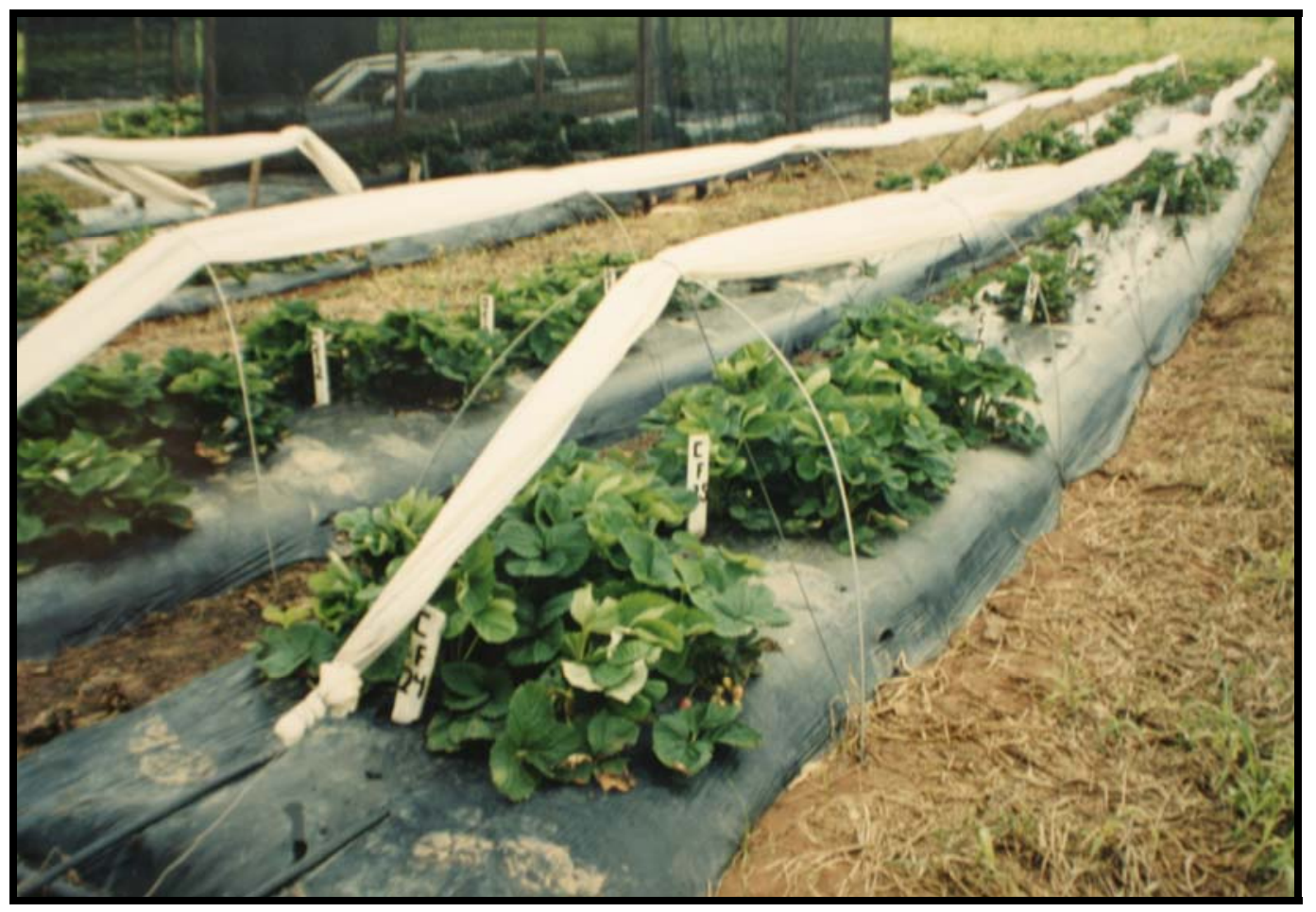

Figura 9 - Canteiros de finais de experimentação.Caldas/MG, 2002

\subsubsection{Variáveis analisadas}

Foram avaliadas as percentagens de sobrevivência, florescimento, frutificação e emissão de estolhos e o peso e número de frutos produzidos por planta. Para isso foram feitas medições a cada três dias. Estas foram posteriormente totalizadas 
em quatro contagens gerais: 15, 30, 45 e 60 dias após o transplante para o campo. Os frutos foram colhidos manualmente de $70 \%$ avermelhados até completamente maduros, contados e pesados.

\subsubsection{Delineamento experimental}

Embora tenha sido utilizado o mesmo delineamento experimental nas duas localidades de experimentação, as análises estatísticas foram realizadas separadamente. Foi utilizado o esquema fatorial 5x2 (cinco cultivares e dois tratamentos de vernalização), em blocos ao acaso,com quatro repetições. Os resultados obtidos foram submetidos a análise de variância através do teste $\mathrm{F}$ e as médias dos tratamentos foram comparadas entre si pelo teste de Tukey, ao nível de 5\% de probabilidade. Cada parcela foi formada por 30 mudas.

Para análise estatística dos dados fez-se necessária a transformação dos dados originais devido a baixa homogeneidade das variâncias. Entretanto nas Tabelas de resultados são apresentadas médias originais para melhor entendimento dos resultados.

\subsection{RESULTADOS E DISCUSSÃO}

\subsubsection{Percentagem de sobrevivência de mudas}

A percentagem de sobrevivência de mudas aos 15, 30, 45 e 60 dias após o transplante em função da cultivar e da vernalização ou não das mudas para as localidades de Piracicaba,SP e Caldas,MG encontram-se na Tabela 8.

Pode-se observar que a vernalização das mudas não teve efeito sobre a percentagem de sobrevivência de mudas em nenhuma das localidades, em nenhuma das cultivares estudadas e em nenhum dos períodos avaliados. A única exceção foi observada para a cultivar Cartuno, plantado em Piracicaba, na análise aos 60 dias após o transplante. Neste único caso a percentagem de mudas sobreviventes foi estatisticamente superior no tratamento em que as mudas foram vernalizadas. 
Entretanto, devido à uniformidade dos demais resultados, considerou-se um caso isolado.

Tabela 8. Percentagem de sobrevivência de mudas aos 15, 30, 45 e 60 dias após o transplante em função da vernalização (Vern) ou não (Test) das mudas e da cultivar para as localidades de Piracicaba/SP e Caldas/MG, 2003

\begin{tabular}{|c|c|c|c|c|c|c|c|c|}
\hline \multicolumn{9}{|c|}{ Piracicaba } \\
\hline & $\begin{array}{l}15 \text { DIAS } \\
\text { Vern }\end{array}$ & Test & $\begin{array}{l}30 \text { DIAS } \\
\text { Vern }\end{array}$ & Test & $\begin{array}{l}45 \text { DIAS } \\
\text { Vern }\end{array}$ & Test & $\begin{array}{l}60 \text { DIAS } \\
\text { Vern }\end{array}$ & Test \\
\hline CAMP & $100.00 \mathrm{aA}$ & $100.00 \mathrm{aA}$ & 87.16 aA & $90.50 \mathrm{aA}$ & $81.05 \mathrm{aA}$ & 89.39 abA & 72.39 abA & $72.01 \mathrm{abA}$ \\
\hline OSO & $83.56 \mathrm{abA}$ & 85.99 abA & $75.50 \mathrm{abA}$ & $73.83 \mathrm{aA}$ & $67.17 \mathrm{aA}$ & $64.39 \mathrm{bA}$ & $49.69 \mathrm{bcA}$ & $48.41 \mathrm{bA}$ \\
\hline SWEET & 86.74 abA & 93.85 abA & 72.16 abA & $93.83 \mathrm{aA}$ & $76.17 \mathrm{aA}$ & $94.94 \mathrm{aA}$ & 63.25 abA & $94.28 \mathrm{aA}$ \\
\hline CART & 85.99 abA & $80.00 \mathrm{abA}$ & 80.50 abA & $53.83 \mathrm{bA}$ & $83.83 \mathrm{aA}$ & 50.50 сA & $82.82 \mathrm{aA}$ & $43.04 \mathrm{cB}$ \\
\hline DOV & $69.45 \mathrm{bA}$ & $79.08 \mathrm{bA}$ & $50.50 \mathrm{bA}$ & $40.50 \mathrm{bA}$ & 33.83 bA & 39.38 cA & $33.33 \mathrm{cA}$ & $33.33 \mathrm{cA}$ \\
\hline CV\% & 32.59 & & 17.40 & & 16.40 & & 4.55 & \\
\hline \multicolumn{9}{|c|}{ Caldas } \\
\hline & 15 DIAS & & 30 DIAS & & 45 DIAS & & 60 DIAS & \\
\hline & Vern & Test & Vern & Test & Vern & Test & Vern & Test \\
\hline CAMP & $93.83 \mathrm{aA}$ & 90.50 aA & 87.16 aA & 80.50 aA & $83.83 \mathrm{aA}$ & $75.50 \mathrm{abA}$ & $81.05 \mathrm{aA}$ & 75.50 aA \\
\hline OSO & 92.16 aA & $60.49 \mathrm{abA}$ & $65.50 \mathrm{aA}$ & 45.49 bA & $50.50 \mathrm{abA}$ & $33.83 \mathrm{bcA}$ & $47.72 \mathrm{abA}$ & $33.83 \mathrm{bA}$ \\
\hline SWEET & $82.16 \mathrm{aA}$ & $90.50 \mathrm{aA}$ & $68.83 \mathrm{aA}$ & $80.50 \mathrm{aA}$ & $53.27 \mathrm{abA}$ & $83.83 \mathrm{aA}$ & $50.50 \mathrm{abA}$ & $75.50 \mathrm{aA}$ \\
\hline CART & $87.16 \mathrm{aA}$ & 73.83 abA & $73.83 \mathrm{aA}$ & $67.17 \mathrm{aA}$ & $64.39 \mathrm{aA}$ & $53.25 \mathrm{abA}$ & $50.50 \mathrm{abA}$ & $50.50 \mathrm{abA}$ \\
\hline DOV & 67.17 aA & 55.50 bA & $20.50 \mathrm{bA}$ & 60.49 abA & 17.16 bA & 29.67 сA & $11.61 \mathrm{bA}$ & 29.67 bA \\
\hline CV\% & 16.68 & & 20.84 & & 31.6 & & 32.22 & \\
\hline
\end{tabular}

Para cada período avaliado, as médias seguidas de mesma letra minúscula na coluna e maiúscula na linha não diferem entre si pelo teste de Tukey a 5\%.

Estes resultados diferem dos obtidos por Baldini (1997) que verificou uma tendência de queda na sobrevivência de mudas quando estas são vernalizadas. A autora argumenta que, durante a vernalização, as plantas utilizariam suas reservas e, devido a isto, teriam uma menor taxa de sobrevivência quando transplantadas para o campo. Entretanto, foi observada apenas uma tendência, já que os dados não foram submetidos a análise estatística.

A mesma autora cita ainda que o choque térmico por ocasião da retirada das mudas da câmara fria e o imediato transplante para o campo também seria responsável pela diminuição da sobrevivência de plantas. Entretanto isto não ocorreu. Pode-se observar na Tabela 8 que em muitas ocasiões a percentagem de sobrevivência de mudas foi numericamente maior justamente nas plantas vernalizadas, e não nas testemunhas com seria previsto. 
Análises realizadas pelo departamento de Fitopatologia da ESALQ demonstraram que a causa da morte de mudas foi a infecção pelo fungo Colletotrichum fragariae, causador da doença comumente conhecida como “chocolate” (Figura 10). De acordo com Tanaka et al (2000), esse patógeno de solo tem sua contaminação favorecida por altas temperaturas e umidade elevada, exatamente as condições observadas no período de experimentação.

Comparando as cultivares dentro de cada tratamento as menores percentagens de sobrevivência foram observadas para a cultivar Dover em todas análises realizadas e nos dois locais de experimentação, sendo que, em alguns casos, os valores foram estatisticamente inferiores aos obtidos pelas demais cultivares. Já a cultivar IAC-Campinas apresentou as maiores médias para percentagem de sobrevivência de mudas em ambas localidades e em todas análises realizadas.

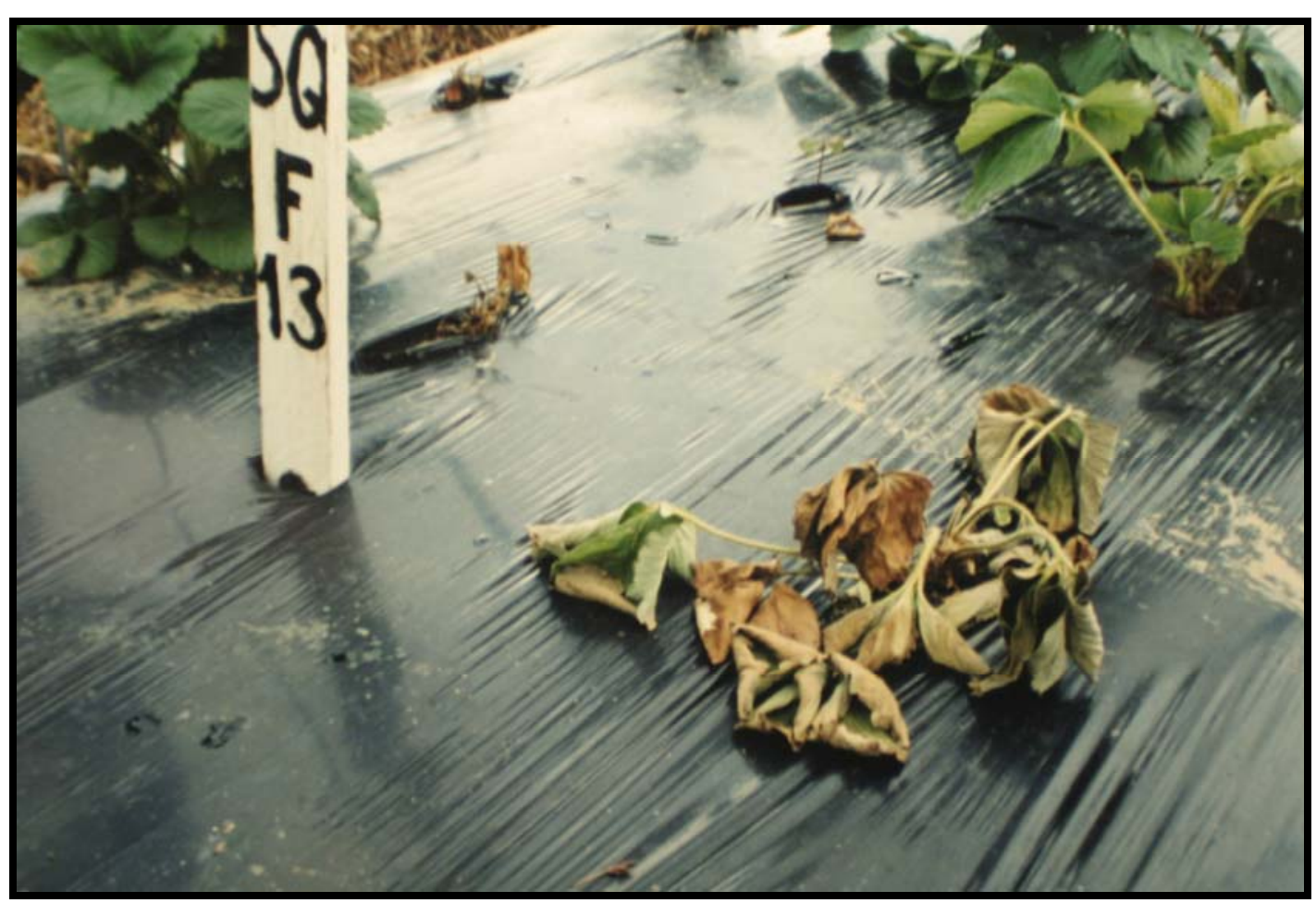

Figura 10 - Morte de mudas de morangueiro devido à ação do fungo Colletotrichum fragariae. Caldas/MG, 2003 
Considerando o fungo Colletotrichum fragariae, como sendo o principal agente causal da morte de plantas ao longo do experimento, as diferenças observadas entre as cultivares deve-se ao diferente grau de susceptibilidade ao fungo inerente geneticamente a cada cultivar. Neste caso, a cultivar IAC-Campinas demonstrou ser a mais resistente e a cultivar Dover a mais susceptível ao fungo.

\subsubsection{Percentagem de florescimento de plantas}

A percentagem de florescimento de plantas aos 15 e 30 dias após o transplante em função da vernalização ou não das mudas e da cultivar para as localidades de Piracicaba,SP e Caldas,MG encontram-se na Tabela 9.

Tabela 9. Percentagem de florescimento de plantas aos 15 e 30 dias após o transplante em função da vernalização (Vern) ou não (Test) das mudas e da cultivar para as localidades de Piracicaba/SP e Caldas/MG, 2003

\begin{tabular}{|c|c|c|c|c|c|c|c|c|}
\hline \multirow{3}{*}{ CAMP } & \multicolumn{4}{|c|}{ Piracicaba } & \multicolumn{4}{|c|}{ Caldas } \\
\hline & $\begin{array}{l}15 \text { DIAS } \\
\text { Vern }\end{array}$ & Test & $\begin{array}{l}30 \text { DIAS } \\
\text { Vern }\end{array}$ & Test & $\begin{array}{l}15 \text { DIAS } \\
\text { Vern }\end{array}$ & Test & $\begin{array}{l}30 \text { DIAS } \\
\text { Vern }\end{array}$ & Test \\
\hline & $48.29 \mathrm{bA}$ & $0.00 \mathrm{aB}$ & $55.55 \mathrm{aA}$ & $20.03 \mathrm{aB}$ & $67.33 \mathrm{aA}$ & $12.23 \mathrm{bB}$ & $70.26 \mathrm{aA}$ & $29.86 \mathrm{bB}$ \\
\hline OSO & $59.23 \mathrm{abA}$ & $2.31 \mathrm{aB}$ & $70.75 \mathrm{aA}$ & $11.58 \mathrm{aB}$ & $73.21 \mathrm{aA}$ & $0.00 \mathrm{cB}$ & $72.81 \mathrm{aA}$ & $0.00 \mathrm{cB}$ \\
\hline SWEET & 88.70 aA & $0.00 \mathrm{aB}$ & $74.99 \mathrm{aA}$ & $0.00 \mathrm{bB}$ & $83.40 \mathrm{aA}$ & $93.64 \mathrm{aA}$ & $72.55 \mathrm{aA}$ & $83.33 \mathrm{aA}$ \\
\hline CART & $80.91 \mathrm{aA}$ & $0.00 \mathrm{aB}$ & $75.00 \mathrm{aA}$ & $0.00 \mathrm{bB}$ & $85.30 \mathrm{aA}$ & $76.54 \mathrm{aA}$ & $72.43 \mathrm{aA}$ & $70.00 \mathrm{aA}$ \\
\hline DOV & $68.60 \mathrm{abA}$ & $0.00 \mathrm{aB}$ & $53.96 \mathrm{aA}$ & $0.00 \mathrm{bB}$ & $65.72 \mathrm{aA}$ & $65.16 \mathrm{aA}$ & $38.83 \mathrm{bA}$ & $44.56 \mathrm{abA}$ \\
\hline CV\% & 16.98 & & 16.90 & & 14.83 & & 7.00 & \\
\hline
\end{tabular}

Para cada período avaliado, as médias seguidas de mesma letra minúscula na coluna e maiúscula na linha não diferem entre si pelo teste de Tukey a 5\%.

A percentagem de florescimento de plantas em Piracicaba foi diretamente afetada pela vernalização para todas as cultivares, tanto aos 15 quanto aos 30 dias após o transplante, sendo que as mudas vernalizadas apresentaram médias estatisticamente superiores às das mudas não vernalizadas para todas as cultivares. Já para Caldas, a vernalização das mudas apresentou efeito apenas paras as cultivares Campinas e Oso Grande, sendo que as demais cultivares não apresentaram diferenças estatísticas entre mudas vernalizadas ou não, já que as mudas de ambos tratamentos floresceram na mesma proporção. 
A Figura 11 apresenta as máximas de temperatura diárias ocorrentes nas duas localidades durante a experimentação. Observa-se que as máximas em Caldas são inferiores às ocorridas em Piracicaba. Este fato justifica que o efeito da vernalização de mudas tenha ocorrido somente em Piracicaba e não em Caldas. As menores temperaturas máximas de Caldas possibilitaram que mesmo as mudas que não tenham sido vernalizadas florescessem com exceção de Oso Grande Em Piracicaba a vernalização das mudas teve efeito significativo, já que as mudas que não foram vernalizadas não encontraram condições para o florescimento devido às temperaturas mais elevadas.

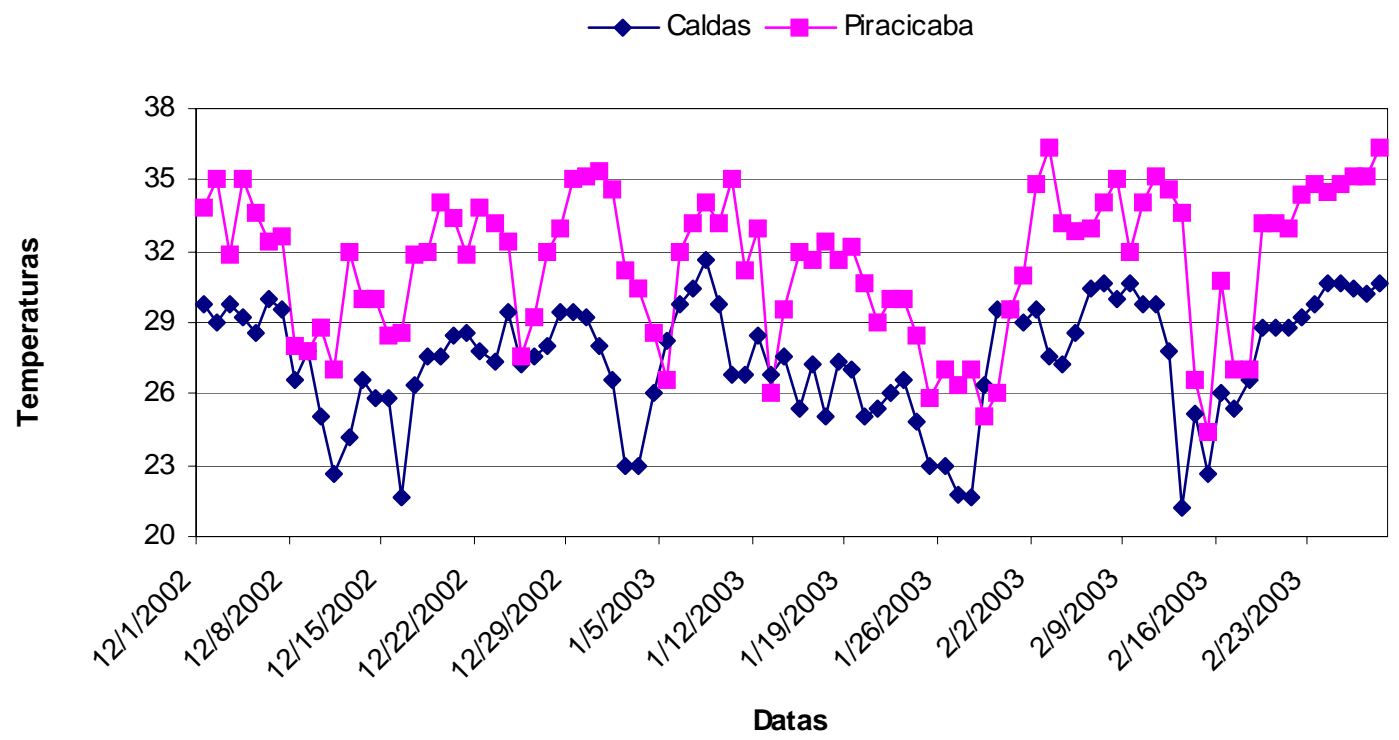

Figura 11 - Comparativo entre as temperaturas máximas diárias observadas nas localidades de Caldas/MG e Piracicaba/SP, no período de 01/12/2002 a 28/02/2003. 
A única cultivar que apresentou plantas florescidas no tratamento sem vernalização em Piracicaba aos 15 dias foi a Oso Grande (2.31\%), sendo que as demais não apresentaram nenhuma planta florescida nesta data. Aos 30 dias após o transplante, as cultivares Campinas e Oso Grande apresentaram 20.03\% e 11.58\% de mudas florescidas respectivamente, mesmo sem vernalização. Entretanto, as médias foram estatisticamente inferiores as das mudas vernalizadas, demonstrando que mesmo neste caso a vernalização teve efeito.

O fato das cultivares Campinas e Oso Grande terem florescido em Piracicaba mesmo sem vernalização das mudas demonstra que tais cultivares apresentam um comportamento fisiológico diferente das demais cultivares, que, sem vernalização, tiveram a percentagem de florescimento de plantas nulo. Goppo et al. (1997) estudando o comportamento de diversas cultivares de morangueiro, constataram que a precocidade de produção e a maturação é variável com a cultivar. Assim este comportamento é uma característica fisiológica de cada cultivar.

Outro fator a ser considerado seria o estresse nutricional causado pelo condicionamento das mudas. Ronque (1998), cita que o estresse nutricional por longos períodos pode induzir o florescimento das plantas quando estas são colocadas em condições favoráveis de desenvolvimento novamente. Neste aspecto, as cultivares Campinas e Oso grande seriam mais sensíveis ao florescimento causado por estresse nutricional do que as demais cultivares.

Em Caldas, a percentagem de florescimento de plantas foi estatisticamente diferente entre os tratamentos apenas para as cultivares Campinas e Oso Grande, aos 15 e 30 dias após o transplante. Para estas cultivares, as mudas vernalizadas apresentaram médias estatisticamente superiores em relação as médias observadas para as mudas não vernalizadas.

As demais cultivares não apresentaram diferenças estatísticas entre mudas vernalizadas ou não em nenhuma das duas análises, sendo que mesmo as mudas que não sofreram vernalização floresceram na mesma proporção das mudas vernalizadas. 
Assim, as condições climáticas foram decisivas para o florescimento ou não das plantas, já que avaliando apenas as testemunhas nos dois locais de experimentação observa-se uma enorme diferença na percentagem de mudas florescidas em Caldas/MG em relação a Piracicaba/SP. As temperaturas médias mais baixas proporcionaram um aumento considerável no florescimento em Caldas, que se igualou ao obtido pelas plantas vernalizadas.

\subsubsection{Percentagem de frutificação de plantas}

A percentagem de frutificação de plantas aos 45 e 60 dias após o transplante em função da vernalização ou não das mudas e da cultivar para as localidades de Piracicaba e Caldas encontram-se na Tabela 10.

Nas condições climáticas de Piracicaba as cultivares IAC-Campinas e Oso Grande apresentaram percentagem de frutificação estatisticamente iguais em ambos tratamentos aos 45 e 60 dias após o transplante. Para as demais cultivares a vernalização das mudas proporcionou médias estatisticamente superiores quando comparadas com as das mudas que não foram vernalizadas, já que estas não tiveram nenhuma planta com frutos durante todo o período de condução do experimento.

Tabela 10. Percentagem de frutificação de plantas aos 45 e 60 dias após o transplante em função da vernalização (Vern) ou não (Test) das mudas e da cultivar para as localidades de Piracicaba/SP e Caldas/MG, 2003

\begin{tabular}{|c|c|c|c|c|c|c|c|c|}
\hline & \multicolumn{4}{|c|}{ Piracicaba } & \multicolumn{4}{|c|}{ Caldas } \\
\hline & $\begin{array}{l}45 \text { DIAS } \\
\text { Vern }\end{array}$ & Test & $\begin{array}{l}60 \text { DIAS } \\
\text { Vern }\end{array}$ & Test & $\begin{array}{l}45 \text { DIAS } \\
\text { Vern }\end{array}$ & Test & $\begin{array}{l}60 \text { DIAS } \\
\text { Vern }\end{array}$ & Test \\
\hline CAMP & $23.12 \mathrm{aA}$ & $26.12 \mathrm{aA}$ & $24.15 \mathrm{abA}$ & 29.45 aA & $85.68 \mathrm{aA}$ & $58.25 \mathrm{aB}$ & $100.00 \mathrm{aA}$ & $66.64 \mathrm{aB}$ \\
\hline OSO & $11.02 \mathrm{abA}$ & $9.65 \mathrm{aA}$ & 8.10 bA & $6.72 \mathrm{aA}$ & $95.71 \mathrm{aA}$ & $40.66 \mathrm{aB}$ & $100.00 \mathrm{aA}$ & $44.86 \mathrm{aB}$ \\
\hline SWEET & 3.76 bA & $0.00 \mathrm{bB}$ & $71.58 \mathrm{aA}$ & $0.00 \mathrm{bB}$ & 60.77 abA & $24.99 \mathrm{bB}$ & 63.44 abA & $19.07 \mathrm{bB}$ \\
\hline CART & $25.29 \mathrm{aA}$ & $0.00 \mathrm{bB}$ & 31.15 abA & $0.00 \mathrm{bB}$ & $69.71 \mathrm{aA}$ & $10.18 \mathrm{bB}$ & 63.39 abA & 8.79 bB \\
\hline DOV & $9.65 \mathrm{abA}$ & $0.00 \mathrm{bB}$ & 23.80 abA & $0.00 \mathrm{bB}$ & $50.00 \mathrm{bA}$ & $0.00 \mathrm{cB}$ & $50.00 \mathrm{bA}$ & $0.00 \mathrm{cB}$ \\
\hline CV\% & 19.50 & & 45.99 & & 19.38 & & & 19.36 \\
\hline
\end{tabular}

Para cada período avaliado, as médias seguidas de mesma letra minúscula na coluna e maiúscula na linha não diferem entre si pelo teste de Tukey a 5\%. 
Analisando as cultivares dentro de cada tratamento, a maior percentagem de plantas com frutos foi obtidas pela cultivar Sweet Charlie, no tratamento vernalizadas, aos 60 dias.

Em Caldas, nas duas análises, 45 e 60 dias, as mudas vernalizadas apresentaram percentagens estatisticamente superiores para todas as cultivares estudadas. Embora tenha havido uma boa quantidade de plantas florescidas no tratamento sem vernalização, esta demonstrou potencializar a capacidade de frutificação das plantas.

Comparando as percentagens de frutificação obtidas nos dois locais de experimentação pode-se observar que as menores temperaturas máximas ocorrentes em Caldas (Figura 11) propiciaram o aumento de plantas frutificadas tanto para as mudas que foram vernalizadas quanto para as que não foram. 


\subsubsection{Percentagem de estolonamento de plantas}

A percentagem de estolonamento de plantas aos 15, 30, 45 e 60 dias após o transplante em função da cultivar e da vernalização ou não das mudas para as localidades de Piracicaba/SP e Caldas/MG encontram-se na Tabela11.

Tabela 11. Percentagem de estolonamento de plantas aos 15, 30, 45 e 60 dias após o transplante em função da cultivar e da vernalização (Vern) ou não (Test) das mudas para as localidades de Piracicaba/SP e Caldas/MG, 2003

\begin{tabular}{|c|c|c|c|c|c|c|c|c|}
\hline \multicolumn{9}{|c|}{ Piracicaba } \\
\hline & $\begin{array}{l}15 \text { DIAS } \\
\text { Vern }\end{array}$ & Test & $\begin{array}{l}30 \text { DIAS } \\
\text { Vern }\end{array}$ & Test & $\begin{array}{l}45 \text { DIAS } \\
\text { Vern }\end{array}$ & Test & $\begin{array}{l}60 \text { DIAS } \\
\text { Vern }\end{array}$ & Test \\
\hline CAMP & $16.33 \mathrm{aA}$ & $18.07 \mathrm{aA}$ & $50.90 \mathrm{aA}$ & 82.19 aA & 83.14 aA & 100.00 aA & 87.65 a A & 100.00 a $\mathrm{A}$ \\
\hline OSO & $7.68 \mathrm{abA}$ & $6.59 \mathrm{abA}$ & $34.27 \mathrm{aA}$ & $74.33 \mathrm{aA}$ & 39.42 bB & $100.00 \mathrm{aA}$ & 93.30 a A & 100.00 a A \\
\hline SWEET & $2.81 \mathrm{abA}$ & $2.61 \mathrm{abA}$ & $43.00 \mathrm{aA}$ & $59.04 \mathrm{aA}$ & $57.08 \mathrm{abA}$ & $83.34 \mathrm{abA}$ & 95.83 a A & 96.15 a $\mathrm{A}$ \\
\hline CART & $0.00 \mathrm{bA}$ & $2.43 \mathrm{abA}$ & $16.66 \mathrm{aA}$ & $34.14 \mathrm{aA}$ & $60.42 \mathrm{abA}$ & $66.07 \mathrm{bA}$ & 96.67 a A & 100.00 a A \\
\hline DOV & $0.00 \mathrm{bA}$ & 0.00 bA & $20.00 \mathrm{aA}$ & 3.02 bA & 30.00 bB & 89.29 aA & 100.00 a $\mathrm{A}$ & 100.00 a A \\
\hline CV\% & 127.44 & & 26.47 & & 18.19 & & 18.97 & \\
\hline \multicolumn{9}{|c|}{ Caldas } \\
\hline & 15 DIAS & & 30 DIAS & & 45 DIAS & & 60 DIAS & \\
\hline & Vern & Test & Vern & Test & Vern & Test & Vern & Test \\
\hline CAMP & $0.00 \mathrm{aA}$ & $0.00 \mathrm{aA}$ & $49.46 \mathrm{aB}$ & $86.60 \mathrm{aA}$ & $66.74 \mathrm{aA}$ & $61.65 \mathrm{bA}$ & 92.50 aA & 99.99 aA \\
\hline OSO & $0.00 \mathrm{aA}$ & $0.00 \mathrm{aA}$ & $4.53 \mathrm{bA}$ & $6.58 \mathrm{cA}$ & 68.57 aA & $76.68 \mathrm{abA}$ & $65.92 \mathrm{abA}$ & $60.33 \mathrm{abA}$ \\
\hline SWEET & $0.00 \mathrm{aA}$ & $0.00 \mathrm{aA}$ & $8.94 \mathrm{bB}$ & $27.26 \mathrm{bA}$ & $69.45 \mathrm{aA}$ & 55.12 bA & $73.87 \mathrm{aA}$ & 99.99 aA \\
\hline CART & $0.00 \mathrm{aA}$ & $0.00 \mathrm{aA}$ & $0.00 \mathrm{cA}$ & $0.00 \mathrm{dA}$ & $57.53 \mathrm{aB}$ & 81.77 abA & $63.31 \mathrm{abA}$ & 38.99 bB \\
\hline DOV & $0.00 \mathrm{aA}$ & $0.00 \mathrm{aA}$ & $0.00 \mathrm{cA}$ & $0.00 \mathrm{dA}$ & $69.34 \mathrm{aB}$ & $100.00 \mathrm{aA}$ & 49.99 bB & $100.00 \mathrm{aA}$ \\
\hline CV\% & 0.00 & & 98.89 & & 6.10 & & 2.25 & \\
\hline
\end{tabular}

Para cada período avaliado, as médias seguidas de mesma letra minúscula na coluna e maiúscula na linha não diferem entre si pelo teste de Tukey a 5\%.

Já aos 15 dias, as plantas das cultivares Campinas, Oso Grande, Sweet Chalie e Cartuno que foram cultivadas em Piracicaba apresentaram estolonamento tanto para mudas vernalizadas quanto para testemunha, enquanto que as cultivadas em Caldas só apresentaram estolões dos 30 dias em diante. Na análise dos 60 dias observase também que as plantas cultivadas em Piracicaba apresentaram percentagens mais altas do que as cultivadas em Caldas para todas as cultivares e em ambos tratamentos.

Este fato pode ser explicado devido as condições climáticas de Piracicaba apresentarem temperaturas mais elevadas do que em Caldas. De acordo com Ronque (1998), em condições de temperaturas elevadas e de dias longos, as plantas 
emitem estolhos que geralmente a cada dois nós, emitem folhas e enraízam. Assim, as temperaturas mais altas de Piracicaba propiciaram a antecipação da emissão de estolões em relação às mudas plantadas em Caldas.

Analisando as cultivares dentro de cada tratamento, aos 15 dias em Piracicaba a cultivar IAC-Campinas apresentou maiores valores em relação às demais cultivares em ambos tratamentos, demonstrando maior precocidade na emissão de estolões. Isto também foi observado em Caldas, entretanto aos 30 dias, já que as condições climáticas com temperaturas mais baixas retardaram a emissão dos estolões para todas as cultivares.

Em Piracicaba praticamente não houve diferença estatística entre os tratamentos, sendo que as condições mais quentes favoreceram o estolonamento para todas as cultivares e em todas as análises realizadas. Apenas na análise aos 45 dias as cultivares Oso Grande e Dover apresentaram percentagens estatisticamente superiores para as mudas não vernalizadas. Entretanto na análise subseqüente aos 60 dias, não foi mais observada esta diferença, sendo que tanto as mudas vernalizadas quanto as não vernalizadas apresentaram percentagens estatisticamente iguais.

Segundo Resende et al. (1999) durante o período de verão, devido principalmente às altas temperaturas, as plantas passam a produzir estolhos, interrompendo a emissão de flores, e conseqüentemente, a produção de frutos.

Observando a Figura 11, pode-se concluir que as temperaturas elevadas em ambas localidades favoreceram o estolonamento das plantas. Mesmo as plantas vernalizadas que haviam florescido e frutificado voltaram a produzir estolões após um curto período produtivo. 


\subsubsection{Peso e número de frutos produzidos}

O peso e o número de frutos por planta em função da cultivar e da vernalização ou não das mudas para as localidades de Piracicaba/SP e Caldas/MG encontram-se na Tabela 12.

Tabela 12. Peso e número de frutos por planta em função da cultivar e da vernalização (Vern) ou não (Test) das mudas para as localidades de Piracicaba/SP e Caldas/MG, 2003

\begin{tabular}{|c|c|c|c|c|c|c|c|c|}
\hline & \multicolumn{4}{|c|}{ Piracicaba } & \multicolumn{4}{|c|}{ Caldas } \\
\hline & \multicolumn{2}{|l|}{ PESO (g) } & \multicolumn{2}{|c|}{ Número de frutos } & \multicolumn{2}{|l|}{ PESO (g) } & \multicolumn{2}{|c|}{ Número de frutos } \\
\hline & Vern & Test & Vern & Test & Vern & Test & Vern & Test \\
\hline CAMP & $0.33 \mathrm{cB}$ & $0.71 \mathrm{aA}$ & $3.20 \mathrm{aA}$ & $1.03 \mathrm{aB}$ & $17.46 \mathrm{aA}$ & $5.81 \mathrm{aB}$ & $3.84 \mathrm{aA}$ & $1.31 \mathrm{aB}$ \\
\hline OSO & $0.86 \mathrm{abA}$ & $0.00 \mathrm{bB}$ & $1.93 \mathrm{abA}$ & $0.00 \mathrm{bB}$ & $10.10 \mathrm{aA}$ & $0.00 \mathrm{bB}$ & $0.67 \mathrm{bA}$ & $0.00 \mathrm{bB}$ \\
\hline SWEET & $0.27 \mathrm{bA}$ & $0.00 \mathrm{bB}$ & $1.38 \mathrm{bA}$ & $0.00 \mathrm{bB}$ & $8.51 \mathrm{abA}$ & $5.42 \mathrm{aB}$ & $2.20 \mathrm{aA}$ & $1.57 \mathrm{aB}$ \\
\hline CART & $0.58 \mathrm{bA}$ & $0.00 \mathrm{bB}$ & 0.97 bcA & $0.00 \mathrm{bB}$ & $2.78 \mathrm{bA}$ & $2.09 \mathrm{aA}$ & $1.38 \mathrm{aA}$ & $0.90 \mathrm{aB}$ \\
\hline DOV & $1.43 \mathrm{aA}$ & $0.00 \mathrm{bB}$ & 0.58 сA & $0.00 \mathrm{bB}$ & $2.29 \mathrm{bA}$ & $0.00 \mathrm{bB}$ & $0.63 \mathrm{bA}$ & $0.00 \mathrm{bB}$ \\
\hline CV\% & 20.91 & & 13.10 & & 22.87 & & 11.99 & \\
\hline
\end{tabular}

Para cada período avaliado, as médias seguidas de mesma letra minúscula na coluna e maiúscula na linha não diferem entre si pelo teste de Tukey a 5\%.

A cultivar IAC-Campinas foi a que apresentou o maior peso e número de frutos produzidos por planta em ambos locais de experimentação nos dois tratamentos utilizados. As plantas cultivadas em Caldas apresentaram maiores produções do que as de Piracicaba, sendo que em ambas localidades as mudas vernalizadas apresentaram maiores médias do que as não vernalizadas, tanto pra peso quanto para número de frutos produzidas por planta.

As médias obtidas em relação ao peso e número de frutos produzidos por planta foram praticamente insignificantes em comparação à dados de produção. Embora a vernalização das mudas tenha propiciado o aumento na percentagem de florescimento e frutificação das plantas, a produção foi drasticamente afetada pelas altas temperaturas ocorrentes no período. Os frutos formados apresentaram má formação e tamanho bastante reduzido (Figura 12). 


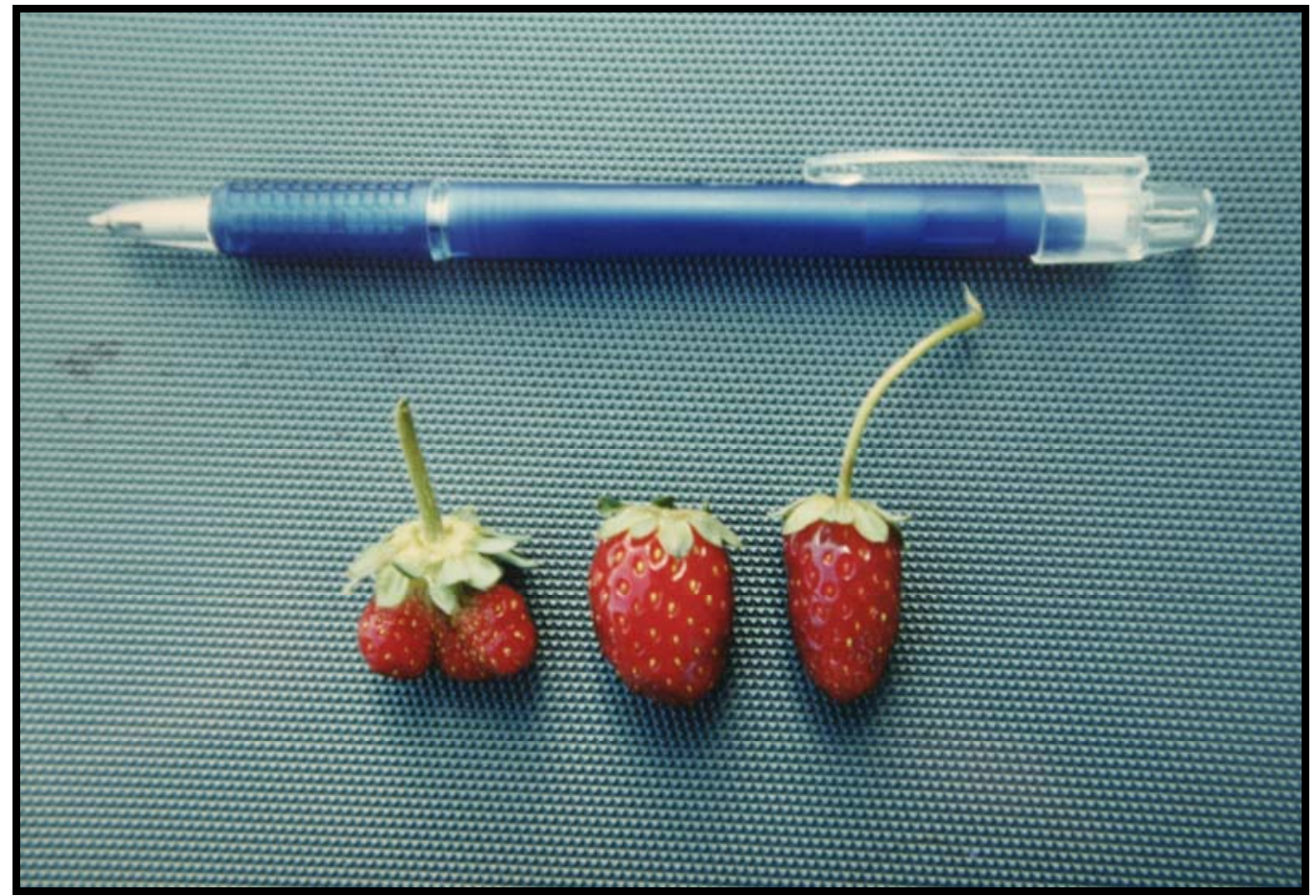

Figura 12 - Frutos de tamanho reduzido e apresentando defeitos devido às altas temperaturas. Piracicaba/SP, 2003

Dijkstra (1989) cita que a produção de frutos de morangueiro decresce conforme mais tardiamente é realizado o plantio das mudas no campo de produção. A menor produção e menor tamanho dos frutos no verão são conseqüências das elevadas temperaturas. De acordo com Ronque (1998) a frutificação é grandemente prejudicada nos trópicos, onde temperaturas mais elevadas fazem com que o morangueiro continue na fase vegetativa, produzindo estolhos indefinidamente. Além disso, elevações da temperatura durante a fase de produção de frutos, tornam estes pouco firmes, ácidos e pobres em sabor.

Assim, pode-se concluir que embora Caldas tenha apresentado temperaturas máximas um pouco mais baixas do que Piracicaba (Figura 11), não foi suficiente para que os frutos se desenvolvessem de forma adequada. Apesar de ter havido florescimento e frutificação de plantas em ambas localidades, as altas 
temperaturas ocorrentes no período prejudicaram o desenvolvimento dos frutos quantitativamente e qualitativamente.

\subsection{CONCLUSÕES}

A vernalização não afetou a sobrevivência de mudas de nenhuma das cultivares e em nenhuma localidade até os 45 dias após o plantio no campo.

Para a localidade de Piracicaba a vernalização das mudas foi significativa no florescimento de todas as cultivares e na frutificação das cultivares Sweet Charlie, Cartuno e Dover.

Para a localidade de Caldas a vernalização das mudas foi significativa no florescimento das cultivares IAC-Campinas e Oso Grande e na frutificação de todas as cultivares. A produção final de frutos obtida nas duas localidades foi comercialmente insignificante.

De forma geral, a emissão de estolões foi desfavorecida pela vernalização até os 45 dias após o transplante. 


\section{CONCLUSÕES GERAIS}

1. O sistema de produção de mudas em vasos suspensos propicia a formação de mudas com maiores teores de carboidratos totais nos rizomas do que mudas produzidas diretamente no solo.

2. As mudas produzidas em sistema de vasos suspensos dentro de casa de vegetação apresentaram vantagens quando comparadas com mudas produzidas no sistema convencional no que se diz respeito à qualidade fitossanitária e fisiológica.

3. A frigoconservação das mudas de morangueiro produzidas no sistema de vasos suspensos nas condições climáticas de Piracicaba acarretou uma baixa percentagem de sobrevivência das plantas após o plantio, mostrado-se inviável dentro da metodologia utilizada.

4. A vernalização não afetou a sobrevivência de mudas de nenhuma das cultivares e em nenhuma localidade até os 45 dias após o plantio no campo. Para a localidade de Piracicaba a vernalização das mudas foi significativa no florescimento de todas as cultivares e na frutificação das cultivares Sweet Charlie, Cartuno e Dover. Para a localidade de Caldas a vernalização das mudas foi significativa no florescimento das cultivares IAC-Campinas e Oso Grande e na frutificação de todas as cultivares. A produção final de frutos obtida nas duas localidades foi comercialmente insignificante. De forma geral, a emissão de estolões foi desfavorecida pela vernalização até os 45 dias após o transplante. 


\section{REFERÊNCIAS BIBLIOGÁFICAS}

ANDERSON, H.M.; GUTTRIDGE, C.G. Survival and vigour of cold-stored strawberry runner plants after different lifting dates, storage temperatures and pre storage treatments. Experimental Horticulture, v.27, p.48-57, 1975.

ASSIS, M. Sanidade do material vegetativo na produção de mudas de morangueiro, In: DUARTE FILHO, J.; CANÇADO, G.M.A.; REGINA, M.A.; ANTUNES, L.E.C.; FADINI, M.A.M. Morango: tecnologia de produção e processamento. Pouso Alegre: s. ed., 1999. p.65-71.

BALDINI, E.M. Vernalização de duas cultivares de morango: produção e análise econômica. Piracicaba, 1997. 54p. Dissertação (Mestrado) - Escola Superior de Agricultura "Luiz de Queiroz", Universidade de São Paulo.

BIGGEY, J. Fraiser qualité du plant frigo. Compltes Rendus Resumes de l' activite fraise. Paris: CIREF, 2000. p55:Lauxade.

BRANDÃO FILHO, J.U.T.; IKUTA, J.; ISHIMURA, I.; IZIOJA, H.; NARITA, N.; ODA, N.; TARGINO, A.; KIMOTO, T. Efeito do tempo de vernalização sobre o florescimento do morangueiro. Horticultura Brasileira, v.7, n.45, 1989.

BRANZANTI, E.C. La fresa. Madrid: Mundi-Prensa, 1989. 386p.

CAMARGO, L. de S.; ALVES, S.; ABRAMIDES, E. Ensaios de variedades de morangueiro. Bragantia, v.22, p.715-729, 1963.

CAMARGO, L. de S.; PASSOS, F.A. Morango. In: FURLANI, A.M.C.; VIÉGAS, G.P. O melhoramento genético de plantas no Instituto Agronômico., v.1, 1993. p.411-432.

CAMARGO FILHO, W.P. de. Estacionalidade da produção e dos preços de morango no Mercosul. São Paulo: IEA, 1994. 5p. 
CARBONARI, R. Produção do morango (Fragaria ssp) em função do processamento de mudas e época de plantio. Piracicaba, 1978, 71p. Dissertação (Mestrado) - Escola Superior de Agricultura “Luiz de Queiroz”, Universidade de São Paulo.

CENTRE INTERRÉGIONAL DE RECHERCHE ET D' EXPERIMENTATION DE LA FRAISE. France. Fraise concept. Fiches Techniques. 1998. 1v.

DARROW, G.M. Interrelation of temperature and photoperiodism in the production of fruit-bulbs and runners in the strawberry. Proceedings of the American Society for Horticultural Science, v.34, p.360-363, 1936.

DARROW, G.M. The strawberries. New York: Holt, Rineehart and Winston, 1996. p.355-65.

DARROW, G.M.; WALDO, G.F. Responses of strawberry varieties and species to the duration of the daily light period. USDA, 1934. 453p.(USDA Tech. Bul)

DENNIS JUNIOR., F.G.; LIPECKI, J.; KIANG, C. Effects of photoperiod and other factors upon flowering and runner development of three strawberry cultivars. Journal of American Society for Horticultural Science, v.95, n.6, p.750-754, 1970.

DUARTE FILHO, J.; ANTUNES, L.E.C.; CUNHA, R.J.P.; ALVARENGA, D.A.; PEREIRA, G.E. Aspectos do florescimento e técnicas empregadas objetivando a produção precoce em morangueiros. Informe Agropecuário, v.20, n.189, p.30-35, 1999.

DURNER, E.F.; BARDEN, J.A.; HIMERRICK, D.J.; POLING, E.B. Photoperiod and temperature effects in flower and runner development in day neutral, junebearing and everbearing strawberries. Journal of American Society form Horticultural Science, v.109, n.3, p.396-400, 1984.

FABY, R. The productivity of graded "Elsanta" frigo plants from different origin. Acta Horticulturae, v.439, n.1, p.449-455, 1996.

FACHINELLO, J.C. Produção de mudas certificadas de morangueiro na Itália. In: DUARTE FILHO, J.; CANÇADO, G.M.A.; REGINA, M.A.; ANTUNES, L.E.C.; FADINI, M.A.M. Morango: tecnologia de produção e processamento. Pouso Alegre: s. ed., 1999. p.65-71.

FERNADEZ, R. Área sul del cinturón verde de Buenso Aires. In: TORHELLI, J.C.; FERREIRA. Producción de frutilla. Argentina: s. ed., 1997. p.92-93. 
FILGUEIRA, F.A.R. Manual de olericultura: cultura e comercialização de hortaliças. 2 ed. São Paulo: Agronômica Ceres, 1982. 2v. 357p.

FNP CONSULTORIA \& COMERCIO. Agrianual 2003: Anuário da Agricultura Brasileira. São Paulo, 2003. 1v.

GALLETA, G.J.; BRINGHURST, R.S. Strawberry management. In: GALLETA, G.J.; HIMELRICK, D.G. Small fruit crop management. New Jersey: Prentice-hall, p.83-156, 1989.

GROPPO, G.A.; TESSARIOLI NETO, J.; BLANCO, M.C.S.G. A cultura do morangueiro. 2 ed. Campinas: CATI, 1997. 27p. (CATI. Boletim técnico, 201)

GUTTRIDGE, C.G. Fragaria. In: EVANS, L.T. The induction of flowering. Melbourne: Mac Millan, 1969. p.247-267.

GUTTRIDGE, C.G. Fragaria x ananassa. In: HALVEY, A.H. CRC handbook of flowering. Boca Raton: CRC Press, 1985. v.3, p.16-33.

GUTTRIDGE, C.G.; MANSON, D.T.; ING, E.G. Cold storage of strawberry runner plants at different temperatures. Explore Horticulture, v.12, p.38-41, 1965.

HARTMANN, H.T. Some effects of temperature and photoperiod on flower formation and runner production in the strawberry. Plant Physiology, v.22, p.407-420, 1947.

JAHN, D.L.; DANNA, M.N. Dormancy and growth of the strawberry plant. Proceeding of the American Society for Horticulture Science, v.8, p.322-330, 1966.

JAHN, D.L.; DANNA, M.N. Effects of cultivars and plant age on vegetative growth of the strawberry, Fragaria ananassa. American Journal Botanty, n.57, p.993-999, 1970.

LARSON, K.D. Strawberry. In: SCHAFFER, B. \& ANDERSON, P.C. Handbook of environmental physiology of fruit crops. 1. Temperature crops. 1994. p.271-297. CRC Press, Boca Raton.

LEITEN, F. Relationship of digging date, chilling and root carbohydrate content to storability of strawberry plants. Acta Horticulturae, v.439, n.1, p.623-625, 1996.

LEITEN, F.; GOFFINGS, G. Effects of temperature and controlled atmosphere on cold storage of strawberry plants. Acta Horticulturae, v.439, n.1, p.445-448, 1996.

LIETEN, P. The use of cold stored plant material in central Europe. Acta Horticulturae, v.567, n.2, p.553-559, 2002. 
LINDEN, R. La conservation des stolons de fraisiers. Fruit Belge, v.32, p.76-78, 1964.

MAC DANIEL, C.N. Photoperiodic induction, evocation and floral initiation. In: GREYSON, R.I. The development of flowers, Oxford: Oxford University Press, 1994. p.25-43.

NICOLL, M.F.; GALLETTA, G.J. Variation in growth and flowering habits of junebering and everbearing strawberries. Journal of American Society for Horticultural Science, v.112, p.872-880, 1987.

ORTIGOZA, L.E.R. Comportamento de diferentes cultivares de morangueiro na produção de mudas de campo. Piracicaba. 1999. 43p. Dissertação (Mestrado) Escola Superior de Agricultura “Luiz de Queiroz”, Universidade de São Paulo.

OKASHA, K.A.; RAGAB, M.I. Cold storage effects on performece and yield of strawberry plants. Acta Horticulturae, v.348, n., p.277, 1993.

PASSOS, F.A. Desenvolvimento de cultivares de morangueiro. In: SIMPÓSIO SOBRE A CULTURA DO MORANGUEIRO. 1., Campinas, 1986. Anais. Campinas: CATI, 1991. p. 1-14.

PASSOS, F.A.; PIRES, R.M.C. Técnicas culturais utilizadas na cultura do morangueiro. Informe Agropecuário, v.20, n.198, p.43-51, 1999.

PASSOS, F.A.; TRANI, P.E.; BETTI, J.A.; TANAKA, M.A.S. Morango. In: INSTITUTO AGRONÔMICO (Campinas, SP). Instruções agrícolas para o Estado de São Paulo. 6.ed. Campinas, 1998. p.222-225. (IAC. Boletim, 200).

REBELO, J.A.; BALARDIN, R.S. A cultura do morangueiro. 2 ed. Florianópolis:EPAGRI, 1993. 40p. (Boletim técnico, 46)

REBELO J.A.; BALARDIN, R.S. A cultura do morangueiro. 3 ed. Florianópolis: EPAGRI. 1997, 44p. (Boletim técnico, 46).

RESENDE L.M. de A.; MASCAREÑAS, M.H.T.; PAIVA, B.M de. Panorama da produção e comercialização do morango. Informe Agropecuário, v.20, n.198, p.519, 1999.

RICE JUNIOR. R.P. Effects of cultivars and environmental iterations on runner prouction, fruit yield, and harvest timing of strawberry (Fragaria x ananassa Duch.). Acta Horticulturae, n.279, p.327-332, 1990.

ROBERTSON, M. Studies in the development of the strawberry: III. Flower-bud initiation and development in large-fruited perpetual "Remontant" strawberries. Journal Horticultural Science, v.30, p.62-68, 1955. 
RODRÍGUEZ, J.P. Morfología del cultivo. In: TORHELLI, J.C.; FERREYRA A. Producción de frutilla. Argentina: s. ed., 1997a. p.01-20.

RODRÍGUEZ, J.P. Situación del área de influencia de la E.E.A. San Pedro. In: TORHELLI, J.C.; FERREIRA A. Producción de frutilla. Argentina: s. ed., 1997b. p.90-91.

RONQUE, E.R.V. Cultura do morangueiro: revisão prática. Curitiba: EMATERIPR, 1998. 206p.

SANTOS, A.M. Influência do tamanho de mudas na produção de morango cv. Lassen e Konoy-Cascata. Horticultura Brasileira, v.5, n.74, 1987.

SATO, G.S.; ASSUMPÇÃO, R. Pólos de produção de morango. Informações Econômicas, v.32, n.11, p.41-49, 2002.

SCARPARE FILHO, J.A. Viveiros para produção de mudas. In: MINAMI, K. Produção de mudas de alta qualidade em horticultura. Piracicaba: Edusp, 1995. p.47-51.

SUGIURA, T. Forecasting of pests occurrence by the plant protection center. Agrochemicals Japan. n.66, 5p. 1995.

TANAKA M.A.S.; PASSOS, F.A; BETTI, J.A. Caracterização de germoplasma de morangueiro quanto a resistência à antracnose do rizoma causada por Colletotrichum fragariae. In: SIMPOSIO NACIONAL DE RECURSOS GENETICOS VEGTAIS. Campinas, 1995. Anais // Campinas: IAC, 1995. p.36.

TANAKA M.A.S.; BETTI, J.A.; PASSOS, F.A. Manejo integrado de pragas e doenças do morangueiro. São Paulo: Secretaria de Agricultura e Abastecimento, 2000, v.5, 61p. (Manual técnico, série especial).

TAYLOR, D.R. The physiology of flowering strawberry. Acta Horticulturae, v.567, n.2, p.245-251, 2002.

TESSARIOLI NETO, J. Produção de mudas de morangueiro (Fragaria $\boldsymbol{x}$ ananassa Duch.) sob cultivo protegido. Piracicaba, 2001. 75p. Tese (Livre Docência) Escola Superior de Agricultura “Luiz de Queiroz”, Universidade de São Paulo.

TESSARIOLI NETO, J.; VERDIAL, M. F.; REIS, F. A. M. Acúmulo de carboidratos em mudas de morangueiro produzidas em sistema convencional e em vasos suspensos. Revista Horticultura Brasileira - Supl 1., v.21, n.2, p.284, 2003. / Apresentado ao $43^{\circ}$ Congresso Brasileiro de olericultura, Recife, 2003. Resumo/ 
YANAGI, T.; ODA, Y. Effects of winter chilling and summer temperature on inflorescence and runner production during summer season in cultivated strawberries (Fragaria x ananassa Duch.). Journal Japan Society Horticultural Science, v.60, p.889-895, 1992. 